\title{
The Heliand
}

\section{Translated from the Old Saxon}

Translated by Mariana Scott 
The Heliand 


\section{IIIIUNC}

From 1949 to 2004, UNC Press and the UNC Department of Germanic \& Slavic Languages and Literatures published the UNC Studies in the Germanic Languages and Literatures series. Monographs, anthologies, and critical editions in the series covered an array of topics including medieval and modern literature, theater, linguistics, philology, onomastics, and the history of ideas. Through the generous support of the National Endowment for the Humanities and the Andrew W. Mellon Foundation, books in the series have been reissued in new paperback and open access digital editions. For a complete list of books visit www.uncpress.org. 


\section{The Heliand}

TRANSLATED FROM THE OLD SAXON BY

MARIANA SCOTT

UNC Studies in the Germanic Languages and Literatures Number 52 


\section{Copyright (C) 1966}

This work is licensed under a Creative Commons CC BY-NC-ND license. To view a copy of the license, visit http://creativecommons. org/licenses.

Suggested citation: Scott, Mariana. The Heliand: Translated from the Old Saxon. Chapel Hill: University of North Carolina Press, 1966. DoI: https://doi.org/10.5149/9781469658346_Scott

Library of Congress Cataloging-in-Publication Data Names: Scott, Mariana.

Title: The Heliand : Translated from the Old Saxon / by Mariana Scott.

Other titles: University of North Carolina Studies in the Germanic Languages and Literatures ; no. 52.

Description: Chapel Hill : University of North Carolina Press, [1966] Series: University of North Carolina Studies in the Germanic Languages and Literatures.

Identifiers: LCCN 66064041 | ISBN 978-1-4696-5833-9 (pbk: alk. paper) | ISBN 978-1-4696-5834-6 (ebook)

Classification: LCC PD25.N6 NO. $52 \mid$ DCC 839.1 




\section{FOREWORD}

Every translation is perforce an interpretation, influenced not only by the personality as well as the training of the translator, but by the age of which he is a product. The best a conscientious translator can do, unless his translation is to become a mere soulless, colorless prose retelling of the original, is to try to become attuned to the mind and the times of the author with whom he is working and then to attempt to reproduce a semblance at least of the melody he hears. $\mathrm{He}$ is aware that he must make certain compromises: neither a literal translation nor one which concentrates on the externals of the metrics will reproduce the ideas and emotions which he knows are present. $\mathrm{He}$ is constantly forced to adapt and to shape. Yet with the adapting and shaping, too, there is inevitably a loss.

It is with these things in mind that I began my work on that

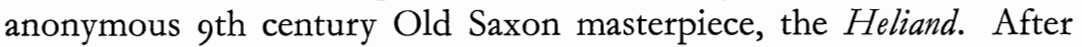
discarding an attempt to confine my vocabulary as much as possible to Anglo-Saxon roots, I settled on a somewhat archaic style as most appropriate for reproducing not only the biblical but somewhat primitive, naive atmosphere of the original. Christ, for example, is frequently called the "Bairn of God." Words like "weeds" for "clothing," "quick" for "alive" have been used - often, however, with the more usual word in the repetition. The various pronominal forms of "thee," "thou," and "ye" have been regularly employed. Since they are so essential to the Old Saxon style, the kennings have been retained wherever possible. So have the repetitions. The name, "Heliand," one of the kennings for Christ and therefore source of the title, has caused some difficulty. "Savior" has become for us a rather colorless word, having few of the connotations of the Old Saxon "Heliand." I have therefore used the translation, "Healer," since so often the emphasis is on His healing both of men's bodies and also their souls. 
It was important for me to remember that the Heliand was originally intended for recitation. This accounts for the very great emphasis on rhythm. While the exact form of the old alliterative verse, though common to both early English and German poetry, proved too confining, a freer adaptation was possible. Let us remember that much of the effect of modern free verse depends on the interplay of sounds: assonance and alliteration. Keeping in mind the purpose of the original, I read my translation aloud as I worked, repeating lines several times, varying and checking rhythms, trying to imitate the surge of the meter and yet avoid monotony. The end result was a line of variable feet, usually a rather free alternation of anapests and iambics with a few scattered tribrachs and spondees, divided by the traditional caesura. I aimed for an alliteration of at least one accented syllable in the first half line with one accented syllable in the second half. If more sounded right, I was delighted. If none worked, I tried to make the rhythm carry the line along to the next cadence. Not all of it, I painedly admit, turned out to be poetry - but then not all of the Old Saxon is!

In the course of my work, I also tried to make a study of the sounds which were dominant in the Old Saxon. By far the most common was the alliteration of "w," followed by "l," " $m$ " and, for certain effects, "s," "b" and the plosives. Since the heavy "w" sound carried the weight of the meter, it was important for me to reproduce it as often as possible. I had good precedent: the Old Saxon author often padded his lines for the same reason with some form of willeon or with such formulas as mit wordun, or wordo eftha werco. Using my precedent, I therefore translated such words as werod or wer as "world folk" and world man, sometimes even - if sense permitted - as "war-folk" or "warrior," etc. Waldand, as an epithet of God or Christ, became "the Wielder." Search for alliteration sometimes even led the Old Saxon poet astray. A very good example of that would be that graf an theson griote - "grave on the sand," after the grave had been described as hewn in the rock. In such a case I considered a translation, "grave in the grotto," not too far from the point. There are many other such cases, though in general I tried to keep as close to the original as possible, both in meaning and in style.

Lastly, I wish to thank all those who have read, criticized, and 
corrected my translation in the six years of my labor. Most especially however, my gratitude is directed to Dr. Philip M. Palmer, now of the University of California at Berkeley, who not only introduced me to the fascination of the Heliand many, many years ago, but undertook the onerous task of checking the many passages about which I still had some doubt. 



\section{HELIAND}

Many there were tensing their minds

To say what was whispered: that Might-Wielding Christ Had here among men done miracles many

With His words and His works. Wise men aplenty, People of earth - all would praise the preachings of Christ,

God's holy Word, and write with their hands

Bright in a book how best God's bidding

They might carry out, the kith of mankind.

There were four from the many: they had might from the Maker,

Help, too, from Heaven and from the Holy Ghost,

Strength from the Savior: so were they chosen for this.

Singly they were to inscribe the Gospel there in a book,

Committing to writing so many commandments of God, Holy, heavenly Word: nor dared any here, Any child of man, emulate them, these four, Picked for the task by the power of God:

Matthew and Mark, as these men were called, Luke, also John - they were beloved of God.

Worthy were they for the work. The Wide-Wielder Had filled the hearts of the heroes with the Holy

Perfectly all with pious opinion, Ghost, And wise words many and still more of wit, That they should begin the goodly Gospel

With their holy voices, raise it on high - 
The Word in this world which has nowhere a like: That it praise Him ever, the Prince All-powerful, The Lord who layeth low the loathsome thing, Who doth stamp out all sin and the hate of Satan, Withstandeth the strife. For He is strong of mind, Mild, too, and good - He who is Master of these, Aethling and Maker, Almighty Lord.

So were those four to inscribe with their fingers, Set down and sing and say forth boldly That of Christ's might and His strength much had they heard

And had seen indeed, which He Himself had here spoken;

Proclaimed and accomplished miracles countless, As He Himself had promised - He, Wielder of Power, Wide Ruling Lord - when He first shaped world, Surrounding it all with a single Word, Heaven and earth and all that they held, Full-worked or still waxing: with God's Word All was encompassed and set forth accordingly Which world-men should rule over widest lands And when each age of this earth should come to its end. There was still one before them - for five had slipped by

For the kinsmen of earth - and now the sixth was to come,

Blessed by God's strength and the birth of Christ, Best of All Healers, and the Holy Ghost, Come to this mid-world to help the many, The world-children all 'gainst the wiles of the Fiend And his secret snares. So to the Roman folk Had Lord God granted the greatest of realms, Had strengthened the heart of the crowds of the host, So that they laid low much land-folk all over. Their helm-wearers had rule from the city of Rome, Their leaders had power in every land o'er the people there,

Over the heathens all. Herod was chosen 
King of Jerusalem over the Jew-folk. Caesar in Rome's city, the mighty ruler, Had set him there 'mid his thanes. Verily, though, He was not kin to the clanships of Israel, not come From their best-born; but his bounty he had Through the grace of Caesar straight from the Romeburg,

So that then the fighting men, famed for their fierceness,

The children of Israel, friends changeless in strength, Were subject to him, since he held sway Herod - over kinships and councillors Of Israel's landsmen. There lived there then An aged man, a wise man of reasonable mind:

He was come from the people of the clan of Levi, The famed son of Jacob of a very fair family: Zachery he was hight, was so holy a man, For he gladly did give service unto God, Worked to His will. So did his wife She was already a very old crone, and no offspring Had been granted to them in their youth. They lived without fault, warding God's love, Were humbly submissive to the King of Heaven, Praising our Prince; nor practiced they evil Among mankind; nor did any meanness, Neither fault nor sin. Still were they sorrowed of soul,

Since not ever could they be granted an heir:

Bereft they of bairns. The bidding of God $\mathrm{He}$ did in Jerusalem. As oft as his duty And the rightness of time did remind him thereof, So oft did he hie himself hence to the holy place, To the High One's temple, to the Heaven-King's house, To serve Him all selfless and make sacrifice, Yearning to work with a God-wise mind. 
The time was then come - as they did tell it,

Wise men with words - that Zachery should stand

watch

There in God's temple. Many were gathered

In Jerusalem there of the folk of the Jews,

Hordes in the holy place. Most humbly they begged

Might-Wielding God for His grace,

The Lord of All Heaven to release them from evil.

The folk stood around by the holy house, and the high-born man

Entered the temple. The others all,

The folk stayed outside of the sanctuary,

The host of the Hebrew, till the holy man

Had worked and had done the All-Wielder's will.

As he took the incense, the sage in the temple,

Round the altar the censer, to serve his Liege -

Piously labored for his own dear Lord;

And gladly he served in God's thralldom

With a generous heart, as one should joyously

Follow one's master. There a fright befell him,

Terror there in the temple. Trembling he espied

God's angel inside there in the sanctuary.

And he spoke to the sage, said with words not to fear

Nor to have any dread. "For thy deeds," quoth he,

"Are of worth to the Wielder and thy words as well.

Thy thralldom has earned thee His thanks, since thou hast believed in Him

And in His strength alone. I am His angel,

And Gabriel I am hight. Ever I stand before God,

Stand in the Almighty's sight, except that He send me forth

On some errand for Him. And now He hight me fare forth, Bade me to tell thee, that to thee a babe will be born

From thy aged wife. In this world shall be given unto thee: 
Wise he of word. Of wine he shall never partake, In life neither of wine nor of cider. So have the Weird

Ones set down:

The Measurers have marked it and the might of God.

He bade that I tell thee: he shall be thane

To the Heaven-King's Self; bade that ye hold him

And faithfully foster him. Quoth that he would find

Honors so many up in God's kingdom.

Quoth that the good man should be called John.

Commanded that ye so call it, that child,

When it doth come. Quoth that Christ's thane

It was to become in this wide, wide world,

Thane of His Own Son. And quoth that they both

Betake themselves here swiftly for tidings."

Zachery then spoke and said to God's angel,

Beginning to wonder about his deeds and his words:

"How can that so come to pass?" quoth he,

"So late in our lives? For us 'tis too late

To win such rewards as thy words have spoken.

For we two were equal of age: twenty winters

Here in this world, when this woman did come unto me;

And together we have shared for seventy winters

Both board and bed, since I chose her my bride.

In our youth we acquired no offspring, no heir,

Could beget no babe in our bedchamber -

Now that we are old, and age has robbed us of deedstrength -

Dulled is our sight and slow are our loins,

Our flesh falleth away, our skin is unfair,

Our limbs unlithe, withered our once-live bodies,

And our appearance: alas, 'tis altered -

Mind both and might: so many a day

We have wandered this world. Methinks 'twere a wonder

If it ever so happed, as thou hast said with thy words." 
Then the Heaven-King's herald was hurt in his mind That Zachery should wonder so at His works And would not believe that Holy Lord God, If $\mathrm{He}$ so willed it, could well make him young, As once he had been. So the angel chastised him, The sage, so that he could not say e'en a single word, Nor speak with his mouth "until thy son is come, Sprung from thy old wife, an earl and shining, Until a young bairn is born to the best of clans Here in this world. Then shalt thou again speak words. Thy voice shall have strength. Nor shalt thou be silent

For any time longer." And straightway it was What the Almighty's angel had there uttered, Had told in the temple: that became true.

Bereft of speech was the sage,

Though a clear mind he bore in his breast.

All day they bided before the God-house, the folk And they wondered all, why this praiseworthy man, This sage should need so long to serve his Master, As never did other thanes in the Lord's thralldom Make such sacrifice with their hands there in the sanctuary.

Lo: the ancient sage did leave the temple. The earls thronged nearer. There was longing in them, To hear what he would say most soothly to them, How wise he would guide them. But no word could he speak

Nor say to his retainers; but with his right hand He instructed the folk to follow God's teachings. The folk understood that verily he had seen Some token from God, though he could not tell them Nor show them the truth. There in his turn He had worked full well our Wide-Wielder's service, As 'twas marked among men. Soon God's might was made known, 
God's strength and His skill: for the crone so aged, The wife was with child. Offspring was granted unto them,

Bairn in the bastion - a so God-like babe.

And the woman awaited the workings of Weird. The winter wore on, the year fell away. John came, A light to the earth-folk: fair was his flesh, Seemly his skin, and shimmering was he of cheek, And the hair of his head and his nails. Now the

$$
\text { hoary, }
$$

The wise gathered quickly, the closest of kinsmen, Wondering much at the work, how well it could happen

That a couple so aged could still bear a child, A babe in the bastion, unless at God's bidding. They well understood that unless this was so, It could never have been - this babe - quite so fair. Then an old man spoke, one of learned and reasonable mind,

Who knew wise words. With zeal he did ask

What the babe's name should be here below in this world:

"Methinks in his way and his bearing he is greater than we.

So I wean that verily God from Heaven hath sent him Himself."

Then the child's mother did straightway speak. She who had borne him did say

With the babe on her lap: "Last year God's bidding Did come unto us, commanded with words of great weight That he be called John, according to the teaching of God.

Even, indeed, if I might, in my mind I cannot, I dare not so change it." Then spoke thereupon A most haughty man: from her homeland he was, "No aethling is named so," quoth he, "no kith of our clan. 
Now then! Let us choose us another, a nicer name.

Later indeed he will like it, if he is so able."

Again spoke the elder, who there could say much:

"I can never counsel any knight whatever

To alter God's word. Let us ask the old man,

The father, who sitteth wisely in his wine-hall there.

Though he cannot speak, say a single word,

He may with his book-letters make us some writing,

May spell us a name." Now he came nearer,

Laid a book on his lap and bade him to write,

To set down wisely with word-mark and sign

What they were to name him, that holy babe.

He took the book in his hand, thought in his heart

Right gladly of God and writ the name John -

Wisely he worked it: and with words thereupon

He did speak unto them, and shrewdly indeed.

Once more he had power to speak, had wisdom and way.

His pain was now past, his punishment dire.

God the Mighty had so made it that in his mind

He could not so soon forget Him, should $\mathrm{He}$ again send

His herald.

I V

'Twas not long thereafter that all came to pass, As Almighty God had promised mankind:

That He would send the Son of Himself,

The Heavenly Bairn, here to this world,

So that He might save the folk all from sin,

The clansmen from hell-pangs. There came His herald,

Gabriel, down to Galilee-land,

The All-Wielder's angel, where he knew a woman of

worth,

A maiden right mild. She was called Mary.

The girl was grown. To a man of good clan,

To a thane hight Joseph her troth she had given,

The daughter of David. A dear wife was she, 
A graceful woman and good. There the angel of God In Nazareth-burg did greet her by name;

Stood there before her and spoke to her for Lord God:

"Hail to thee, Mary!" quoth he, "Loved by the Maker art thou!

Aye, worthy art thou of the Wielder, for thou hast wisdom,

Lady, gifted with grace. Glorified art thou ever Above all women. Be thou not weakly of mind, Nor fearful of heart. I come not to hurt

Nor to bring thee a gull-thing. Thou shalt be our God's,

Be our Master's mother here among men, bearing a manchild,

Son of the Heaven-King. His name shall be Healer Here mid the earth-folk. His end cometh not,

Nor hath whereover He ruleth ever an end - His realm He, Finest of Folk-Leaders." The fairest of women, The maiden then answered unto God's angel,

The loveliest among ladies. "Lo, how may that be?" quoth she,

"That I shall bring forth a son? Never knew I man in my life."

The All-Wielder's angel had ready his word

To answer the maid. "From the meadows of sky

The Holy Ghost shall descend through the strength of God.

From Him will a Wee One be granted thee here in this world.

The Wielder's strength will o'ershadow thee,

The Heaven-King All High with His shade.

Below was never a birth so fair,

Never so wonderous down among men. For from God's might

It cometh here to this world." The heart of the woman was again

Utterly turned to God's will at these tidings. 
"All ready stand I," quoth she, "for such service, If He will so have me. His handmaid am I.

I trust in these things. Therefore let it then hap,

As thou sayest with thy word, as is His will, My Lord's, my God's. My mind doubteth not,

Nor my word nor my way." So I heard that the woman

Received God's tidings all gladly indeed

With a shimmering soul, with bright shining truth

And faith clear and fair. The Holy Ghost became

The Babe in her womb; and in her breast,

In her heart itself she understood. She said to all whom she wished,

That she had conceived through the All-Wielder's strength,

Holy from Heaven. Then was Joseph's heart,

His mind right worried. For this maiden,

This pious woman, this high-born wife

He had bought as his bride. He knew she had bairn within her,

Yet he thought not a whit but that his wife

Had kept herself carefully. He could not yet know

The Wielder's blithe tidings. But to make her his bride

He no longer wished, his wife in his halls.

And thus he began to think in his mind

How he might forsake her, yet cause her no hardship nor sorrow.

He wanted it not noised nor known about

Among the many. He feared that the children of men

Would bereave her of life. For this was the land-way, The hallowed, old law of the Hebrew folk:

Whensoever a woman was unightly wed,

She must pay with her life for this bedship.

Never was lady so good that she could long live

Mid the land-folk, could live 'mid the world-lords.

Then in his mind the wise man, the good man, Joseph,

Began to bethink himself of these things, 
How he might slyly forsake the girl.

'Twas not long thereafter that the Almighty's angel Hurried to him in a dream, the Heaven-King's herald, And bade him keep her and care for her well And love her, too, in his mind. "At Mary," quoth he, "thy maid,

Be not thou wrathful; she is a right good wife.

Scorn her not sternly. Thou shalt hold her And ward her well in the world, as before, Fostering thy love-pledge and thy friendship as well. Nor let her be loathsome to thee, though she hath Bairn 'neath her limbs, A babe in her womb. Through God's bidding It cometh, Through the Holy Ghost from the Heaven-heath here. Jesus Christ is that Babe! God's own Bairn shall He be, The All-Wielder's Son. Thou shalt hold Him well

With holiness, too. Nor let thy heart doubt, Nor thy mind be disturbed." Then the man's heart Was turned by these words, so that he again won love for this woman,

For the maid, Marie. God's might he now understood, The Wielder's bidding. Great was his will, That he should hold her, in holiness keep her. He cared for her in his home. And she carried all cleanly

The Holy Ghost - all for God's glory, The Man of Goodness, until God's fate-word Reminded her mightily that unto the light of mankind She should bring Him, the Best of all Bairns.

$$
\mathrm{v}
$$

There came from Rome-burg from the mighty man Over the earth-folk, from Octavian himself, Ban and bidding over his broad fealty;

This was come from Caesar unto every king: To the home-sitting ones as far as the war-lords 
Wielded their power o'er the people and land.

'Twas hight that all men habited outside their own boroughs

Should seek now their homeland, all heroes their heritage,

To bide their lord's heralds; each landsman should go

Quickly to the clan of his kinsmen,

To the burg of his birth. The ban was proclaimed

Over this wide, wide world. And the world-folk did gather,

In every bastion the men all. The messengers fared forth,

Those come from Caesar, book-learned thanes.

And neatly they wrote each name on a scroll,

Both land and the man, so that no lord could avoid it,

No man his tax; but all must pay tribute,

The heroes each for his head. So to his homeland

Came Joseph, the good man, as God the Almighty, The Wielder had willed it; with his family he came,

Sought his shining castle, his lordly seat, The bastion at Bethlehem, where they both did dwell, Hero and holy maid, Mary the good.

There stood in earlier days the shining throne

Of the high-born king, of the earl of the Hebrews, Of David the good, as long as he governed

And kept lofty seat. They were his kith,

Were come from his clan, were of good kin all,

Both through their birth. Then I heard that the bright tidings

Admonished Mary, and the might of God:

That on this site a Son should be hers,

Born here in Bethlehem, the Mightiest of Bairns, The Strongest of Kings. Come was the Shining One,

Mighty here to man's light, as for many a day

Pictures of Him and tokens aplenty

Had foretold in this world. So all had turned true, As the sages had spoken it in the long, long ago.

Through His Own Self's strength, how most surely He would come 
To this earth-realm here - with humility - He, Protector to many. Then His mother did take Him, And she swaddled Him well, the fairest of women, With garments and goodly gems. With her two gracious hands

She lovingly laid Him, the Little Man, The Child in the crib, though He had God's strength, The Master of Men. There His mother sat by Him, The woman there waking; she herself warded Him, Held there the Holy Bairn; and her heart doubted not The mind of the maid. It became known to the many Over this wide, wide world. The warders did hear it: Grooms were they there, keeping guard outside, Were war-men on watch; with the horses they were, With the beasts in the field. And lo: before them they saw

The darkness divide in the air. Down came God's light Through the clouds came shining, surrounding the grooms Afar in the fields. And sorely they feared, These men, in their minds. Then God's mighty angel They saw coming afar. To them together he spoke, Hight that the grooms not dread any grief From the light. "For lo!" quoth he, "A glad thing I tell you and truly, long longed-for tidings

Bespeaking great power: for in this selfsame night Christ, Blessed Bairn of our own God, is born in the bastion of David,

He - our Master All Good. That is joy to mankind, The weal of all folk. So that ye may find The Mightiest of Babes in Bethlehem-burg, Take this as a token that I now tell unto you With soothy words: that He lieth swaddled, A Child in a crib, though He be King Over earth and heaven and the children of men, All-Wielder o'er World." Verily as he spoke this word, There was come with this single one of the angels A multitude down from the meadows of Heaven - 
A holy host, the fair folk of God.

They spoke, lauded greatly the Lord of Mankind.

They raised holy song, as they returned through the clouds

To the meadows of Heaven. And the warders did hear

How the great host of angels gave praise unto Almighty God

With these words most reverently: "Honor be" quoth they,

"To our Lord Himself in the highest, to the King of Heaven -

And on earth be peace to all children of men, To folk of good will who accept their God

With hearts ever pure." The herdsmen understood That a mighty thing had admonished them: Blithe tidings there. They turned back to Bethlehem That selfsame night, for their spirits longed Most greatly to see Christ Himself.

\section{I}

The angel of God had shown unto them the shining token, So that they themselves - they could wander forth To the Bairn of God. Straightway they found Him, the Babe,

The Lord of Mankind, the Master of Peoples. They praised God the Wielder, and with their words They made known far and wide in the shining castle What tokens holy they had seen indeed from the meadows of Heaven,

What signs there, fair in the field. The woman full well Kept these things in her heart, the holy virgin, The maid in her mind: whatever she heard the men there saying.

Fittingly she reared Him, the fairest of women;

With her love the mother did raise the Master of Men, The Holy Heavenly Bairn. The heroes did speak 
On the eighth day, the earls of the kingdom, Very wise men all, with the handmaid of God:

That His name should be "Healer," as the Heaven King's herald,

As God's holy angel, Gabriel had spoken, Had bade the woman with words of truth, When she first conceived Him, so fair in this world. God's angel she followed, and right gladly, too. For great was her will to hold Him in holiness. The year strode on, till the Peace-Child of God Had forty days and as many nights, too. There a deed needed doing;

To Jerusalem they must take Him, to the Wielder's temple.

That was the way then, the world-folk's custom, Which no Hebrew woman would dare to neglect, But that when she had brought forth her first-born son She needs must take him to the Lord God's temple. So they did travel, Mary and Joseph, the good folk twain, Both from Bethlehem. The Babe they had with them, The Holy Christ. They sought then God's house In Jerusalem; they accomplished the custom of Jew-folk, Made sacrifice unto the Wielder there in His sanctuary, To God in His temple. There they found them a good man, An old one, hard by the altar - aethling-born he So many summers and winters had he spent in the temple, Lived in the light, working God's love With a clean soul. Holy spirit he had And a joyous heart. Simon was he hight; Long had the Lord's power pointed out to him That he would not leave the light of this world, Until 'twould be granted him to see with his eyes Holy Christ Himself, the King of the Heaven.

His heart was most blithe in his breast, when he saw the Bairn

Coming into the temple. He gave thanks to the Wielder, To Almighty God, that with his eyen he had seen It. 
To Him he did go and gladly received Him, The old man with his arms: all well he did know The sign and the symbol, and the Child of God, The Heaven-King Holy. "Now, Lord," quoth he, "I gladly shall bid Thee, since aged I be, To let me, Thy most humble thane, take leave from here,

To fare forth in Thy peace to where my forebears did dwell,

Folk in this world, since my wish is fulfilled The dearest of days: I did see my Liege, The Loveliest of Lords, as long, long ago It was promised unto me. To all peoples Thou art the Light - great Light to all heathen lands,

Who have not yet accepted the All-Wielder's power.

Thy coming, o Master of mine, O my Lord, my dear Lord, Is glory and honor to Israel's children, To Thine own landfolk, Thy beloved people." Secretly then the old man there at the altar Spoke to the good woman, truly did tell her How her Son would become to some certain ruin, To some consolation, to the children of men A love-thing to those who list to His teaching, But harm yet to them, refusing to hearken

To the gospel of Christ. "Thou shalt suffer," quoth he, "great care

And hurt in thy heart, when the earth-children here

Will kill Him with weapons. This thy great work will be:

To suffer this sorrow." The Maid understood all, The wise man's words. There came, too, a woman From inside the temple. Anna was she called, Was Phanuck's daughter. Full well her Lord had she served

With a grateful heart, was an excellent woman. 
After her maidenhood, when a man's wife she became, An earl's on his estate, this excellent girl,

With her husband she had held sway

Seven years o'er his lands. I heard that she then suffered grief:

That the great might of the Measurer

Did divide them, Weird most woeful. A widow,

She dwelt in the temple eighty and four

Winters here in the world. Well she had served Him, her God

And her Lord, day and night, never leaving the temple.

She, too, came to this selfsame place. Straightway she

$$
\text { saw - }
$$

She knew God's Holy Bairn, to the heroes announced it, To the folk at the altar, this spell all welcome.

Said that so near was the Savior's salvation, The help of the Heaven King. "Now Holy Christ, The All-Wielder Himself, is come to the sanctuary To deliver the folk who have bided so long, So many a while in this mid-world here Poor people they - so that in this present thing Mankind all may rejoice." Many were joyous, The world-folk there in the temple: they heard the glad tidings

Spoken by God. The woman had ended the sacrifice, As her vow and the book in the shining bastion had told her,

Her handwork most holy. They went on home

To Jerusalem, Mary and Joseph,

The Holy Family. They had the Heaven-King

At their landhouse ever, the Son of the Lord,

Protector of many. Thus to the people it was not made known -

Not further known in the world; but so was His will, The Heaven-King's mind. 
Although all holy men

Recognized Christ, at the court of the king

It was not yet known to the men who in their minds

Were not rightly inclined; rather concealed from them

With words and with works, until the wise ones, Those men from the East did come to the folk, Swift lords on the long way over the land.

Bright beacon they followed and sought God's Bairn;

And with pureness of soul they purposed to kneel

And confess themselves as His thanes.

So they brought to pass the Providence of God.

When they found Herod enthroned on high,

King, speaking slime-words, as mighty he sat

Mad with his men, ever anxious for murder -

They addressed him gravely in kingly wise,

In his house the sages; and straightway he asked them

What business had brought them out here,

These war-men from far, far away. "Whether ye carry

wound gold

To give to some man? To whom are ye going,

Travelling on foot? What? I know not whence ye come from afar,

Earls of another folk. I see ye art aethling born, Kin of good clan. Never before are come here

Such envoys from another land, since over this folk of men

I have wielded my power in this great, wide realm.

Ye shall tell me truly before these retainers

Why ye art come indeed to this land."

They answered in turn, the men from the East,

Word-wise warriors. "We can," quoth they,

"Most easily tell thee our business with truth,

Rightly reveal why we are come here on this road

From the east of this earth. Aethlings were there,

Good speaking men, who promised us good 
And help aplenty from the King of Heaven Verily with their words. There was a wise man there, Hoary and sage - so long ago was that now -Our ancestor there in the East - nor has any man since then

Ever spoken so sharply. God's spell he could tell, For the Lord of the Land-people had lent him the gift To hearken up from the earth

To the All-Wielder's word. His wisdom was great, The thoughts of that thane. Then when he was to depart, To forfeit his home and the crowd of the human folk, Forsaking the life of the landsmen - and seek the other light:

Then he called his followers all to come closer His heirs were they there - and to the earls He most soothly said what is since then come, Hath happed in this world: A Wise King would come here, Mighty and shining come to the mid-world, Best by His birth; quoth that God's Bairn He would be; Quoth that in this world He would wield power Eternally through all of time over heaven and earth; Said that on the self-same day, when $\mathrm{He}$ - so blessed Was born to His mother on this mid-world here So quoth he - in the East would shine a single white star,

In the heavens on high, such as never before we have had

Between earth and heaven or anywhere else:

Neither such Bairn nor such beacon bright;

That three men from the people should go offer prayer;

Hight them think well when they would see God's beacon

Rise in the East, hight they should ready themselves straightway;

Hight that we should follow where'er it might fare Westward over the world. Now well it hath happed, Come through God's power: a King is born, Bold $\mathrm{He}$ and strong. We have seen the beacon shining bright 
Over Heaven's stars. So I know Holy God, The Mighty One, hath marked it Himself. Every morn we did see it,

This brilliant star shining. So we followed the beacon here,

The while through ways and through woods. That was our greatest wish -

To see Him ourselves, to know where to seek Him, The King in this kingdom. Tell us to which clan $\mathrm{He}$ is born."

There arose in Herod's breast a great rage 'round his heart.

Spirit and heart began to seethe with sorrow within him, For he heard them say that he should now have a Head over him,

A mightier King and One of good clan, Blessed 'mongst His folk. Then he ordered them all To gather together, what good men there were, In Jerusalem the wisest with their speech and their words,

And in their breasts in book-craft

Most verily learned. And he asked them with words, Most anxiously asked them - this evil-souled man, The king of the people - where Christ would be born In this world-realm here, the Peace-Wielder Good. Then the folk replied, the people most truly; Quoth that they knew quite well that $\mathrm{He}$ Would be born in Bethlehem. "So 'tis writ in our books And wisely inscribed, as the truth-sayers, Those full wise sages, have spoken it further: That from Bethlehem the Herdsman of Bastions, The Loved Warder of Land should come to the light; The Counselor of Clans should come to His rule O'er the hordes of the land-folk; and His grace will hover

Mild o'er this mid-world for the peoples many." 
There I heard that as soon as the evil-souled king

Told the truth-sayers' word to the travellers, the earls from abroad

Those faring from far - he questioned them fully,

When first on the east-path they had then seen it The king-star acoming, the token all clear,

Bright and high in the sky. They wished to hide nothing from him

And truly they told him. He hight them travel, Go forth on their way; hight that they fathom the news Of the New Child's coming; and the king himself, The master of Jews, gave order most sternly

To the wise men three that when they fared from the West,

That they should give him account where he could seek that King

In His hall and His home. Quoth that he with his thanes Wished to reverence the Bairn. But he thought to become His slayer by the weapon's edge. Yet All-Wielding God Was minded elsewise. He could accomplish, Could finish far more in this light: for that shines still long -

The prophesied power of God! There appeared the symbol Clear 'neath the clouds. Those men, wise and clever, made ready

To travel. They fared forth now from there, Bold on their mission. They would seek God's Bairn, They themselves and alone. No thralls had they with them,

But they were just three: well versed in such things, Were indeed clever men, who came carrying their gifts. Then they saw it so wisely shining forth 'neath the clouds,

High in the heavens, where fared the white stars. They recognized clearly the beacon of God - through Christ it was worked 
Here in the world. The world-men went following it, Full piously thence. Those who could further them, Until they well saw, these way-weary men, The clear beacon of God bright in the heavens Suddenly stop. The star shone light And white o'er the house where for His will Dwelt the Holy Bairn. And the wife did keep Him, The Maid most fittingly. The minds, the hearts of the thanes

Became blithe in their breasts. Through the beacon's light they well understood

That they had indeed found the Peace-Bairn of God, The Holy King of the Heaven. When they entered the house, Did go with their gifts, the great of the East, The way-weary men - quickly the warriors

Did know Him rightly, All-Wielding Christ. In reverence now

They fell on their knees before Him, the Child. In kingly wise

They greeted the Good One and gave Him their gifts Gold and incense as tokens of God, And myrrh with it. The men stood ready,

Fair before their Lord. And with their hands all fittingly

They took Him and held Him. They betook themselves then,

The wise men, into the house - way-weary were they The sages into the guest hall. There the angel of God Did come to the sleepers, showed a dream in the night, Revealed in a vision, as the Lord Himself, The All-Wielder, did will it. They thought a man had commanded with words

That they seek them another way: the aethlings should Leave and go to their own land and not seek the loathsome man,

Herod, the mad-minded king. Then morning did come Shining down to the world. The wise men began 
To tell each other their dreams. They did rightly

fathom

The All-Wielder's word. For great wisdom

They bore in their breasts. They bade the All-Wielder,

The Heaven-King on High, that hencefore they might still

Work His grace and His will; quoth that their souls were turned unto Him,

Their minds every morn. Then the men travelled hence, The earls from the East, as the angel of God Had told them with words. They took them another way, Following God's message. Nor would they give The king of the Jews account of the birth of the Babe; But as they did will it, they went on their way, The road-weary men, saying nothing.

IX

Soon after the Wielder's,

God's angel did come and to Joseph did speak, In a dream did say to the sleeper at night The Master's own herald - that the slime-mouthed king

Would seek Him indeed, the Child of God:

He was after His life. "Now thou shalt lead Him

Out into Egypt-land, live midst the land-folk

There with God's Bairn; and with God's handmaid as well Thou shalt dwell with the folk, until unto thee cometh The Word of the Master, that thou mayest lead The Holy Bairn, lead the Lord back to this landscape." Then from his dream Joseph did waken, jump up In his great hall. God's orders He soon recognized; started out on his way, The thane with the Maid. Over the mighty mountains He sought other folk. For he wished to lead forth God's Bairn from His foes. Soon after the word Came to Herod the king, as he sat in his kingdom, 
That the wise men were gone from the West Home to their Eastlands, had fared on another way. He knew that they had not wanted to tell him the news Here in his halls. Then his heart was troubled, His mind most mournful; quoth that the men had done this,

The heroes, to scorn him. So he sat there sorrowed, Bitter rage in his breast. Quoth that a better idea, Another he had now thought out. "I know His age now, Know His winters' number; thus I can now bring it to pass

That on this earth He shall never grow old, Here 'mid my hosts." So Herod sent harshly A command o'er his kingdom. The king of the people Hight his men go forth; hight them behead with their hand-strength

So many a babe, bairns born in Bethlehem And bred these two years. The thanes of the king Did evil deed. So had to die there, Though sinless, many a man-child. Never since nor before

Such a pitiful killing of young kin was there, Such a wretched death! The women wept.

Many mothers did see their sons killed and dead; Nor might they help them a whit, with their two hands hold them,

With their arms embrace them, their own dear bairns, Their loved and little ones. But life it had to relinquish -

The babe in front of its mother. Their misdeeds these

$$
\text { rogues }
$$

Saw not, saw not their sins. With the sword's edge They committed great crimes. They cut down many A child-young man. The mothers bewailed The death of their babes. Care was in Bethlehem, Loudest lamenting: if they had lashed Their hearts with a sword's edge, they could not have hurt 
Them worse in this world. The women many, The brides there of Bethlehem: they saw before them their bairns,

The child-young men lying murdered:

Bloody they lay on their laps. The baneful murderers

Killed the innocent crowd. From their crimes

They refrained not a whit: it was their will

To kill Christ Himself. But God, strong and clever, Saved Him from them and their hatred. In the night He had the earls lead Him to Egypt-land, The good men with Joseph to the green fields, To the richest earth, where that river floweth, The Nile-stream wide, north to the sea, The fairest of floods. There the Peace-Bairn of God Dwelled as He willed until Weird did remove Herod the King. Hate-filled, forsook he the children of men,

The life of the earth-folk. O'er his lands

His heir was to rule. Archilaus

He was hight, hero of helm-wearers - he!

He was to rule o'er the Jewish folk there in Jerusalem, Wield power o'er the people. Then the word did come There in Egypt to the aethling man:

That he spoke to Joseph - God's angel himself,

The Lord God's herald. Hight him again lead the Babe

Back to the land. "Now he hath left the light,"

Quoth he, "Herod the king. Once 'twas his will to kill Him,

Delivering Him from this life. Now in peace ye may lead

The Child to His kinsmen. Now the king liveth not,

That insolent earl." Joseph understood

God's token completely. Straightway they readied themselves,

The thane with the Maid. They speedily sought to go thence,

Both with the Bairn. Bright fate they fulfilled, The will of the Wielder, as He bade them with words. 
Mary and Joseph were again come to Galilee-land;

The Holy Family of the King of Heaven

Were with Him at Nazareth-burg. There he waxed 'mid the folk,

Our saving Christ. He grew full of sense, full of knowledge,

And the grace of God was with Him, and great the love

Of His mother's kin: like no other man was He,

This Youth in His goodness. When twelve years He did have,

When such an age He'd attained, there the time was then come,

When they in Jerusalem, the Jewish folk all, Should serve their Lord, their God Himself And should work His will. They were in the temple There in Jerusalem, the Jews all together, Mighty gathering of men. And Mary herself Was there in the crowd; and her Son she had with her, God's Own Bairn. When they now had made sacrifice goodly, The earls at the altar, as their law did order, Had fulfilled their folk-way - the folk fared thence, The world-men as they willed it; while in the temple Stood God's Mighty Child, though His mother most truly

Knew nothing of it. Now, she weened He had left, Had fared with her friends. She first found it out On the day that came after, the aethling's wife, The holy Maid - that He was not 'mid the men-folk. Then Mary's spirit was deeply in sorrow, Her heart most troubled, that she did not find the Holy

Child

Among the crowd. Greatly she was grieved then, The handmaid of God. She hied herself to Jerusalem once more

To seek her Son. And she found Him sitting 
Inside the temple, where sat the sages, The very wise men who verily read And learned God's law, how with their words They could work the praise of Him Who created this world.

There sat in their midst God's Mighty Bairn, All-Wielding Christ - although those who there warded The temple could not recognize Him even a whit. And anxious for knowledge, $\mathrm{He}$ asked them questions With wise words indeed. They wondered all How so childlike a Man could utter such speeches, He with His mouth. There His mother did find Him Sitting down 'mongst the sages; and she greeted her Son,

The Wise 'mid the folk. And with her words she did speak:

"Why, dearest Man, hast Thou given Thy mother Such sorrow indeed, that I needs must seek Thee I, worried wife, a woman so troubled, Among these burghers?" Then answered the Bairn

With wise words, indeed: "What? Thou knowest right well," quoth $\mathrm{He}$,

"That I here belong; with happiness here Most rightly dwell where My Mighty Father Wieldeth His powers." The woman understood not, Nor the sages there in the temple, why He said such a word,

Did speak with His mouth such a sentence. Mary kept all

Concealed in her breast, what she heard her Bairn speak With His wise words. Then they went from there, Left Jerusalem both, Mary and Joseph. They had with them the Son of the Lord, The Best of all Bairns that was ever born, Child from a mother: they had for Him mighty love With pureness of heart, and He hearkened to them, God's Own Bairn to His blood-kin, 
To His parents twain through His humble mind. In His childhood He never sought to reveal His greatness of strength, that so mighty a power $\mathrm{He}$ did have in this world; but He bided His time In proper manner thirty years in the midst of the people, Before $\mathrm{He}$ would show a single token, Say to the people that He Himself was Here in this mid-world the Master of Mankind. 'To Himself He had kept it, God's Holy Bairn The word and the wisdom and all His great wit, His very wise mind. From His words no man would know, From His speech, that such wit was His -

That this Hero harbored such thoughts. But as was proper to Him,

He awaited the shining token: His time was not come yet,

When He o'er this mid-world should make it wide known, Should teach the folk to follow their belief And to work God's will. But many well knew, Folk in the land, that He was come to the light, Though they could not recognize Him all clearly as yet,

Until He Himself would indeed say the word.

XI

John had grown up out of his earliest youth, Had waxed in the wilderness. Nor was there any worldman

But him alone who so served All-Wielding Christ. Faithful His thane, he forsook the multitude, The company of men. Then came to him mightily There in the wilderness word from Heaven:

God's goodly voice gave John command To proclaim Christ's coming, proclaim His great strength

Wide o'er this mid-world with words of truth; 
Hight that he say that the true Kingdom of Heaven Was close for them, the children of mankind, In this landscape here was near for the land-folk, The most wonderous riches. His will was great

To relate to them of such blessed raptures.

He set out and went where the water, The Jordan did flow all joyfully there, Made known through the land to the landsmen all day, To the folk that with fasting they might atone For many a wrong, make better their sins themselves. "That ye may now become clean," quoth he. "The Heavenly Kingdom is close

For the children of men. Ye yourselves in your minds In your spirits, too, rue all your sins, rue The hurts ye have done against folk, and hearken ye to my teachings,

Turn to my words. Into the water

I shall dip you all deatly, though from your deeds, Your sins, though, themselves I cannot absolve you That ye through my handwork are henceforth cleansed Of your loathsome deeds. But $\mathrm{He}$ is come to this light, Mighty to mankind, and standeth right in your midst; Though ye yourselves do not want to see Him, He will baptize you both in the name of the Lord And of the Holy Ghost. He is Lord High over all. He can free each man from his misdeeds, Shear him from sin, who would be blessed of soul Here in this world, if such be his will: To do what God's Own Dear Bairn doth command For these earth-folk here. As His herald now I am come to this world and shall make Him His way, Teaching the clansmen to keep their belief Through pureness of heart, that they go not to hell Nor face the fire. Full glad be his soul then, Joyous so many an hour - whosoever forsaketh sin And the devil's ambush: he acquireth the grace Of the Good One, the Heaven-King - he who hath a heart pure and loyal 
For Almighty God." Many an earl

Through these teachings, many folk truly,

World-men did ween that this was All-Wielding Christ,

Since he did so speak so much of soothness,

Such words of truth. Then wide and far it was known

To every man over the promised land,

To all kin in their courtyards: then there did come

Jewish folk seeking him out from Jerusalem,

Grooms from the bastions, and asked if he were God's Bairn

"About whom so long," quoth they, "the land-folk have spoken,

The world-men said verily, that he should come to this world."

But John took the word and boldly did speak

To the heralds. "I am not," quoth he, "God's Bairn,

The Verily Wielding Christ. But I am here to make way

For Him, for my Lord." The heroes then asked,

The earls who were hearing asked the herald then;

Those from the town asked him for tidings. "If thou are not truly God's Bairn,

Art thou then Elias, who in earlier days

Was amid the folk? Certainly he is again

Come on this mid-world. Say what manner of man

Art thou? One of those who was once here,

One of the soothsayers? What shall we say

To the folk, tell them of truth? Never was come

To this mid-world another man ever

So famous of deed. Why dost thou dip

These folk here, if the foretold Savior

Thou art not?" Then John the Good wisely gave answer:

"I am the foreboder, the envoy of Him, of my Master,

My beloved God. I am to make ready the land,

The world-folk right to His will. Through His word indeed

My voice is made strong, though few understand it,

The world-folk here in the wilderness. In no way am I like unto Him, 
Like my Master and Lord. He is mighty of deed, Is so noble and strong - that shall be soon known to the many,

The war-men here in this world - so that I am not worthy

Of tying the lace of His shoe, though His own slave

I be - and He so lofty a Lord; so much better

Is He than I. No herald on earth

Is His equal now nor ever shall be

On the face of this world. Keep ye your will with Him,

$O$ ye folk, your belief, for long shall ye be

Then joyous of heart; for the forces of hell

Ye have forsaken and the evils of life; and seek ye then for yourselves

God's light, home of all heavenly good, eternal kingdom,

High meadows of Heaven. Nor let ye your hearts be in doubt."

XII

So the young man told, as were God's teachings,

Revelations to mankind. Many did gather

In Bethany there, the bairns of Israel -

Came there to John, the king's underlings all,

People to learn, and received belief.

He dipped them each day and reproached them their deeds, Their will to do wrong; and for them praised God's Word,

The Word of his Lord: "The Heavenly Kingdom," quoth he,

"Standeth ready and right for all men who are mindful of God

And believe in the Healer with pureness of heart,

And list to his teachings." He was not long there,

That from Galilee came God's Own Bairn,

Our Dear Lord's Son, seeking to be dipped.

Our Good Wielder's Bairn was now so grown

That among the land-folk He had lived

Thirty winters here in this world. As was His will, 
He came there, when John baptized them in Jordan's

stream,

Dipped the folk right dearly and all day long.

Straightway when he saw his Master Sweet,

His Lord, his heart grew blithe, for that was his wish,

And with words he addressed Him: this goodly man, John, spoke to Christ:

"Now Thou art come to my dipping, my Lord, O my God, Thou Best of Folk-Rulers. So I shall do for Thee,

Since Thou art the strongest of kings." Christ Himself hight him,

The Wielder all verily, that he utter such words no more.

"Knowest thou that it is fitting," quoth $\mathrm{He}$ "that we now fulfill

Forthwith all that is right, as is truly His will?"

John stood and dipped much folk all the day,

Many world-men in water; and also All-Wielding Christ,

The High King of Heaven, with his hands he baptized

In the best of baths; and he bent his knee

To pray, strong as he was. And Christ arose,

Fair from the flood, Peace-Bairn of God,

The Lord of all Land-Folk. When He entered the land,

Heavens door did ope, and from the All-Wielder above

Came the Holy Ghost, came down to the Christ.

He came in the likeness of a lovely bird,

A strong, fair dove, and He sat Him down upon our sweet

Lord's shoulder,

Hovered over the Wielder's Bairn. Then word came from Heaven,

Loud from the high, cloudless vault, and greeted the Healer Himself,

Christ, the Best of All Kings. Quoth that He Himself had chosen

Him from His kingdom. Quoth that He loved His Son

Best of all born men. Quoth that He was His all-dearest

Bairn.

As God willed it for him, John verily saw this

And heard it as well. Soon after this he did make known 
To the children of men that they had a Mighty Lord, "This is," quoth he, "the Heaven-King's Son, The One All-Wielder. Of this I will be witness Here in the world: for God's word did tell it, The voice of my Lord, when He hight me dip them, The world-folk in water, when I truly did see The Holy Ghost mightily coming down from Heaven's meadows,

Seeking a single Man in this mid-world here.

'That,' quoth that voice, 'that will be Christ, The Fair Son of the Lord. He shall dip the folk In the Holy Ghost and heal many a man

From his dire misdeeds.' This power He doth have from Lord God:

That He can remove from all mankind

Their blame and their sins. This is Christ Himself, God's Own Bairn, the Best of all Men, Bulwark against the baleful fiend. Well - ye may be joyous of mind

Here in this world. As it was your will, While still alive, to see your Land-Ward Himself. Released from its sin, many a soul, Many a ghost will go to his God, will be Freed from his misdeeds, which here toileth loyally with friends

And firmly believeth in All-Wielding Lord, In Christ Himself. That will be of great help,

Of goodly avail to all men, whosoever gladly so do."

\section{XIII}

Then I found this to be: that to all folk, To all peoples, John praised Christ's teachings, Those of his Lord, through which they could win The Kingdom of Heaven, the holiest of goods, Blessed life eternal. But He Himself, our Lord so good, 
The Son of The Wielder went in the wilderness

After the dipping. He was there in the desert, Our Lord of Earls, a long, long while,

Nor had He more folk about Him, more men in His following.

He Himself chose it to be even so. He wished To be tempted by the most terrible of demons, Strong Satan Himself, who drives folk to sin, Drives men to their misdeeds. He knew Satan's mind, The evil will of the varlet, who once in this world At its very beginning betrayed them, the earth-folk, Seduced them with sinfulness, since he caused those two, Partners in wedlock, Adam and Eve, to become untrue Through deceit - so that the children of men After their earth-trip must travel to hell, The ghosts of all folk. This God Almighty All-Wielder, $\mathrm{He}$ - wanted to change; He wanted to give to the earth-folk all

The high realm of Heaven. Therefore He sent here a Holy Herald,

Sent His Son Himself. Then Satan was filled

With hate in his heart. He begrudged Heaven's kingdom

To the children of men. He aimed to cheat Him, the Mighty,

Cheat the Son of the Lord with the selfsame tricks

With which he had once so treacherously

Gulled Adam himself, so that he grew hateful to God He deceived Him with sin: the same he minded to do To All-Healing Christ. But He kept steadfast His heart 'Gainst the wicked wight - the All-Wielder's Bairn Kept hardened His heart. He wished Heaven's kingdom Secure for the land-folk. The Land-Warden lay lonely For forty nights. He did fast there, The Master of Mankind. As long as He partook not of meat,

Then they did not dare, those devilish wights, The hate-minded fiends, fare nearer unto His face Or greet Him. He weened that that long He was truly as God, 
Unmixed with something of mankind - the Mighty One Heaven's Holy Warder. As He let Himself hunger, So that $\mathrm{He}$ began to want meat because of His manliness, There came closer the Fiend after the forty days, The murky misdoer. He weened that surely $\mathrm{He}$ was simply a man.

Then he went and spoke unto Him with these words. The spear-foe did greet Him: "If Thou art God's Son," quoth he,

"Why hast Thou not, if 'Thou hast the power,

Ordered these stones to be bread, and, Best of all Bairns, Hast not healed Thyself of Thy hunger?" Then spoke again Holy Christ:

"The children of men," quoth $\mathrm{He}$, "may not live alone By bread, the earth-folk all, but they shall be In this world for the teaching of God and shall do the works

Which have been proclaimed aloud by the Holy Tongue, The gums, the voice of Lord God: that is a good man's life,

For the kinfolk all, that they accomplish

What they are bidden by the word of the Wielder." The noisome fiend came nearer then For another time and slyly tempted And baited his Master. The Peace-Bairn of God suffered The will of the Evil One and indeed gave him power That he might try himself against His great might. He let him lead Him - the scourge of the land-folk And take Him on to Jerusalem there to the temple of God:

High over all on the very highest of houses

He did set Him up and spoke scorn-words to Him, The Evil One with such mockery. "If Thou art the Al-

$$
\text { mighty's Son," }
$$

Quoth he, "glide down to earth. Long hath it stood Written in books that He hath bidden The Almighty Father - bidden His angels That they be Thy warders on all of Thy ways, 
Hold Thee under their hands. Why then? Thou mayest

never

Stub even Thy foot on any hard stone."

Then spoke again Holy Christ, the Best of all Bairns:

"So it is also most rightly written in books," quoth

$\mathrm{He}$,

"That thou shalt not try Him, shalt not tempt Thy Master, Thy Liege Lord ever. That befits thee not in the least."

For a third time then He let the scourge of the land-

folk

Take Him up high on a mountain. There the treacherous

Fiend

Let Him look over all of the land-folk,

Over winsome goods and the worldly kingdoms

And all such possessions as the earth surrounds

For fairer use. And there spoke The Fiend once again to Him,

Quoth that He would give unto Him all those so goodly things,

These noble fiefdoms, "If Thou wilt kneel before me, Fall in front of my feet, confess me Thy lord, And pray at my lap: then will I let Thee enjoy All these possessions, which I have here placed before Thee." No longer would He listen to the loathsome word; Holy Christ no longer would hear, but He drove him forth,

Away from His favor; swept Satan away, and then spoke:

The Best of All Bairns bade that men all should pray

To Almighty God; and Him alone

Should they serve - the many thanes,

The heroes hoping for grace, "There help will reach

Every man whosoever he be." Then the menace of men,

Satan himself became saddened of mind;

The devil went down to the dales of hell.

There came much folk from the Almighty above down to Christ:

God's angels did come to give unto Him

Friendship and following and to serve Him faithfully, humbly, 
As one should one's God, one's Liege, the King of Heaven Himself, for His grace.

XIV

For a long while then, God's Blessed Bairn dwelt in the wilderness,

Till it seemed to Him better for the benefit of all

That He show His great strength to the folk. Thus $\mathrm{He}$ forsook

The shade of the forest, the spot in the wood, And again He did seek the company of earls, The illustrious thanes and the throngs of men, And He betook Himself to Jordan's shore. There John found Him,

The Peace-Bairn of God, his Master all good, The Holy Heaven-King. And he said to the Hero, John, His disciple, when he saw Him coming:

"That is the Lamb of God, who shall release the folk In this wide, wide world from their wicked sins, All men from their misdeeds: glorious Master, Most Strong of All Kings!" Christ then went forth To Galilee-land, God's Own Bairn Fared to His Friends, where fair He was born And most rightly reared; and related with words, Christ 'mongst His kinfolk, the Richest of Kings, How they themselves should atone for their sins; Hight them to rue their harmful works many, To let fall their false deeds: "Now 'tis fulfilled, As the old men have said, as the sages did speak, Promised help unto you from the Heavenly Kingdom. Now it is near through the Savior's strength. And ye shall rejoice therein,

Each of you will gladly give service to God

And will work His will." There arose joy 'mid the worldfolk,

'Mid the gathered crowd. Christ's teachings became sweet 
To the followers all. He began to gather together Youths for disciples, young men and good, Word-wise warriors. He went to the shores of a water, There where the Jordan had spread to a sea On the border of Galilee-land. There He saw sitting Andrew and Peter, found the two by the flowing water. The brothers both down by the broad stream

Were very neatly throwing their nets, Fishing in the flood. There first the Peace Bairn of God

Himself did greet them on the shores of the sea.

Hight that they follow Him, quoth that He would give them

Much of God's kingdom. "As ye here catch fish, So shall ye both with the force of your hands fetch the children of men,

So that they may enter the Kingdom of Heaven,

People aplenty through your message and word." Much pleased of spirit were they,

Both of the brothers. They perceived God's Bairn, Their beloved Lord. They left all things,

Andrew and Peter, whatever they owned by the flood, Had won by the water. Truly the will was great in them To go along with the Bairn of God, To be in His retinue and to reap blessed reward. So do all folk who would earn their Lord's favor And would work His will. As they went along The shores of the water, they met a sage Sitting by the sea and his sons twain, Jacob and John, young men on the Jordan. Sons and father, they sat on the sands;

Neatly they knotted and mended their nets With both their hands, the nets which the night before They had slit in the sea. Then He spoke unto them; God's Blessed Bairn bade them be on their way now with Him.

Jacob and John, they both did go, 
The child-young men. Christ's word was for them

So worthy here in this world, that on the shores of the water

They forsook their father alone by the flood, The ancient alone, and all that they owned, Their nets and their well nailed ships. They chose All-Nurturing Christ, Holy Savior and Lord. To earn His help Was the need they felt. So feel all thanes, All warriors here in this world. Then the All-Wielder's Son

Went forth with the four. And He chose the fifth; Christ picked at a market place a king's young vassal, A wise-minded man: Matthew was he hight.

A thane was he to an aethling-born.

There he was to take with his hands tithe and toll

For his lord; loyal he was to his task,

Noble his looks and his bearing. But he left them all -

Gold and silver and gifts so many,

Treasures most dear - and became our Lord's man.

The king's thane chose Christ for his Lord, A more generous Gift-Giver than ever his master Had been in this world. He received a worthier thing, Longer lasting gains. It became known to the landfolk,

To each in his bastion, that the Bairn of God Was gathering disciples, and He Himself spoke So many a wise word and such words of truth, That shining wonders He did show them and tokens

Did work in this world. Through His works It was visible, through His deeds as well, that $\mathrm{He}$ was the Master, The Heavenly Lord who had come to help The children of men in this mid-world here The land-folk toward light. 
To the land He oft made this clear;

For He worked there so many a wonderous token, As $\mathrm{He}$ healed with His hands the halt and the blind, Relieved many land-folk from loathsome ills, From such sickness as at that time Fiend Satan Had thrown on the children of men - the hardest of all, Long lasting illness. The land-folk came there Day after day, where our Dear Lord was Himself with His faithful, until many folk Were gathered together, a very great crowd Of land-folk, though they were not all come with a like belief,

World-men all with one will: some sought the AllWielder's Bairn --

Poor men were they and in want of food -

So that they might beg Him amid the multitude For meat and for drink, amid the crowd; for there was many

A goodly thane who gladly did give

Of his alms to the poor. And again there were some, Clans of the Jews, sly folk were they. They were come to this place,

So that they might discover our Master's deeds And His words as well. Stealthy of mind were they, Wrathful of will. They wanted to make All-Wielding

\section{Christ}

Loathed by all land-folk. Thus would they not list To His teachings nor turn to His will. Some others were sages,

Wise men indeed and worthy of God:

Among the people the pious. They were come for the preaching of Christ,

So that they might hear the Holy Word And learn and listen. Their belief they had firmly established - 
They had pious hearts; and straightway they became

His thanes,

So that on the day of their death He would take them to the dearest of goods -

The Kingdom of Heaven. Christ gladly received

So many of mankind and granted unto them His merciful rule

For a long, long time - for that so well He could do.

There was a great crowd gathered round glorious

Christ:

So much of the folk was assembled. He saw them come from all lands,

From all the wide ways, the world-men together, Fine folk and strong. His fame was spread far

To many a man. Then the Mighty Christ

Went up on a mountain, the Mightiest of Bairn;

And He sat aside from the rest. There He chose for

\section{Himself}

Twelve specially picked, men true and loyal Good folk whom $\mathrm{He}$ wished with Him as His vassals, Disciples of Him, their Master, each day.

He called them by name and bade them come nearer:

First surely Andrew and Peter also, The brothers twain, and these two with them, Jacob and John - they were worthy of God. Mildly inclined was His mind unto them. They were one man's sons

Both through their birth. The Bairn of God chose them, These fair ones, as followers; and much folk, too, Most famous men: Matthew and Thomas, The Judases twain and the other Jacob;

He was a cousin of His - they were come from two sisters,

Come from the same clan, Christ and Jacob, very good kin.

Now All-Healing Christ counted nine of His men, Loyal hearted thanes they. Then He hight the tenth also come 
And join His disciples: Simon was he called.

And He called Bartholomew, too, to fare up the mountain A way from the folk. And Philip was with them.

True hearted men were they all. The twelve went together,

The fighters all to the confab, there where the Councillor sat;

The Protector of Many made known unto them

How He planned to help mankind 'gainst the pangs of hell,

'Gainst the infernal flame - help those who would follow

The fair, sweet message, as He sought to reveal it There in His wisdom to the world-folk many.

X V I

Then they stepped nearer to All-Saving Christ, Such disciples, as He had chosen Himself, The Wielder amid His vassals there. And the wise men The heroes, stood all gladly about God's Son, The war-men most willingly; they awaited His word, Thought and were silent, longing to hear what the

$$
\text { Lord of the Land-folk, }
$$

The Wielder Himself, would make known with His words

For love of the land-folk. There sat the Shepherd of

$$
\text { Lands }
$$

Across from his good men, God's Own Bairn.

With His talk 'twas His will to teach them - the people Wise words aplenty: how in the realms of this world They could best bring about bounteous praise of our Lord.

He sat there, was silent -- our Holy Savior -

And looked at them long. Our Lord was gracious of spirit,

Mild was His mood; and as He unlocked His mouth, The All-Wielder's Son did show them with words 
Many a marvelous thing; and to the men He said Such wise words - to them, whom $\mathrm{He}$, All-Wielding Christ Had chosen here for this speech: those of the children of earth

Who were worthiest of God, men of good clan. He spoke to them soothly; and said those were blessed, The men on the mid-earth, who in their minds, Their hearts, were poor for humility's sake. "For to them is given

The Eternal Kingdom, the holiest of Heaven's meadows, Life without end." And He also told them, That blessed were, too, the gentle and mild. "They may inherit this glorious earth,

The very same kingdom." Quoth that those, too, were blessed

Who bemoan here their misdeeds. "Await joy they may, Consolation perfect in their Master's kingdom.

Blessed be those who have done good, heroes who justly have judged:

For their piety they will be plenteously filled In the kingdom of God: such good things will greet them,

These world-men who have judged well and justly. Nor will they be cheated

In secret, when they sit at the confab. Blessed be also such men

Whose hearts are mild in their heroes' breasts. For them will the Holy Lord,

The Mighty, be mild. Blessed those 'mid the folk

Who have cleaned their hearts: They will see the Heaven-Wielder

In His own kingdom." Quoth that they, too, were blessed

Who live in peace 'mid the folk. "Have started no feud, no affair,

With their doing. Sons of the Lord indeed they'll be called. 
For He Himself will be gracious to them, Most gladly will they

Long enjoy the Lord's kingdom." Quoth that they, too, were blessed,

Those war-men who ever will right, "and through this willingly suffer

The harm and hatred of richer men. To them is the Meadow

Of God's Heaven then given, and the spirit's good life Forever, for all days, and the end never cometh Of the winsome possessions." So All-Wielding Christ Had told the earls 'round about Him of eight blessed states; Through these shall each one straightway find Heaven, if that be his wish;

Or he shall be deprived of joy and possession For eternal times, as soon as he exits this world, Life's fate on this earth, and seeketh another light, Either a fair one or a foul - even as he hath lived 'mid the folk,

Worked with them here in the world. Thus He spoke with His words.

All-Wielding Christ, the Richest of Kings, The Own Bairn of God did say to His disciples;

"Ye shall also become blessed," quoth $\mathrm{He}$, "because the people,

The folk of the land will fight you, speak evil of you all,

Hold you up to scorn and harm you muchly Here in this world; and working worse wrong, Condemn you with sinful speech and so much of hatred; Denying your teachings and doing loathsome deeds, Harm for your Lord's sake. But let ye your hearts still be happy,

Your lives ever, too, since reward standeth ready for you

In the kingdom of God; and every good, also, Great and manifold: that is given unto you as a gift, 
A treasure, since here first ye have toiled, have endured

Pain in this world. It is worse for those others:

Grimmer judgment awaits them who have goods here on earth,

Wide worldly treasure. They waste here their pleasure, Enjoy them enough. These men shall suffer

A harrowing judgment after their journey.

They shall bemoan their misery, who are now so merry

And living in lust, nor let go willingly

Their sinful thoughts, which tempt their spirits,

Their loathsome wrongs. For them shall come as reward

An evil most painful. These people will see sadly

$$
\text { their plight, }
$$

Face troubled their end. All sore shall their spirits

$$
\text { be, }
$$

For too much in this world they followed their will, These men, as they were minded, indeed. Now for their misdeeds ye shall

Reproach them, rise against them with words, as I now shall reveal unto you

And most soothly say, O ye, My disciples,

With words of truth: that of this world

Ye shall henceforth be the salt of sinful mankind, Absolve them from bad deeds, so that to a better thing They may turn the land-folk: to forsaking the Fiend's

$$
\text { work, }
$$

The deeds of the devil; and to seeking their dear Lord's realm.

So with your lessons ye shall turn the land-folk To My will. However, if any of you fade away, Turn aside from the teachings which are entrusted to you,

Then ye are like unto salt which is scattered Wide on the seashore; then it is of worth to none, And the bairns of the land-folk will walk on it with their feet, 
Men grind it in grit. All who are to proclaim it, God's

Word,

Will thus suffer: if he permiteth his spirit to doubt, If he is not bent to spur men to the blithe realm of

Heaven,

But wavereth in his word - then the Wielder groweth

grim,

The Almighty is enraged, and the children of men, also.

To the bairns of the earth he will become hated,

To all the land-folk, if his lesson be not of worth."

XVII

So spoke He wisely and said God's spell.

The Land-Warder taught them, His people with pureness of mind.

The heroes stood gladly 'round the Son of God, World-men to His will. They longed for His words;

They thought and were silent. They heard Him say it -

The Lord of the Land-folk give God's law to the children of men:

He promised them Heaven and thus spoke to the heroes:

This, too, I may tell you, My disciples, most truly

With soothy words: that ye henceforth shall be

The light in this world to the bairns of the lands-

men,

Friend to all people and over much folk,

Shining and winsome: nor may your great works

Remain hidden, nor yet with what hearts ye proclaim

them -

No more than a castle can remain ever concealed

Which standeth on a mountain or steep on a cliff,

A giant-made work. No more can your words

In this mid-world, your deeds be hidden to men. Do as

I teach you:

Let your light shine forth large to the land-folk,

To the bairns of men, that they may know your minds and your souls, 
Your words and your will, and thus praise All-Wielding

God,

Their Father in Heaven, with pureness of heart;

Here in this light praise Him who gave this lesson to

you.

Let him who hath light leave it not hidden from the land-folk,

Nor cover it heavily; rather high in his great hall

He shall set it up, so that all within shall have sight thereof,

The heroes in the great hall. Even so may ye not hide

The Holy Word from the folk here in this land,

Keeping it from man's kind; but the commandment of

God

Ye shall spread abroad so that all the bairns

Over this large landscape, the folk shall indeed understand.

And so do ye that which in former days

The wisest men did speak with their words,

When they then, the earls, did follow the old law, And for this reason as well, as I now say unto you:

That all men may serve God as the old law doth bid them.

Never ween for one instant that I come to this world

To lay low and destroy the old law

Among the people, or to contradict the word of the prophets,

Who, as men of truth, gave clear commandments

In days of yore. Sooner shall both fall apart,

Heaven and earth, which are held bound together,

Before any word which verily the wise men

Commanded the folk remaineth one whit unfulfilled

Here in this light. I came not to World

That I should fell it, the prophets' word, but to fulfill it rather -

To enlarge it and make it anew for the aethling bairns, For the good of this folk. That was formerly written 
In the old law: ye have oft heard it spoken

By word-wise men: whosoever doth act thusly here in this world,

That he berefts another of his old years,

Whosoever cheats him of life: to him shall the children of men

Deal out death; and now I shall tell you more deeply, Shall discuss it still further: whosoever shall foster hatred,

One man 'gainst another, deep in his mind -Who beareth a grudge in his breast, though they be all brothers,

God's blessed folk, bound together in kinship, Men into clans. And still a one becometh so grim of mood

'Gainst the other, that he would rob him of life, if he could right well do it,

Then he is straightway doomed - deprived of bis life,

Is indeed so judged, as was the other

Who through the might of his hands cut off the head Of another earl. Also in the law it is written

With words of truth: and ye all know it well That with all one's heart one should love one's neighbor,

Most zealously love those closest, be kind to one's kinsmen,

Good to all kith, and mild in one's gift-giving; Have love for his friends and hate for his foes, Withstand them with a strong, with a strife-eager heart,

Ready 'gainst their evil and wrath. But I relate yet another law,

A fuller one still for the folk: that ye have fondness now for your foe,

In your heart love him well as ye would your kin And in God's name ye so do it. Do ye much good unto him, 
Show him pureness of spirit and loyalty sweet;

In return for his loathsomeness do ye love him. That is long lasting counsel

For every man whose mind hath been turned In hate 'gainst his foe. Ye shall all gain from this, For ye shall be called the Heaven King's sons, His bairns all blithe. Nor may ye find better counsel Anywhere here in this world. I verily tell unto you, Say to each bairn, that ye may not bring Your goods with an angry heart into God's temple, Into the Wielder's house: it be not worthy For Him to accept, as long as ye harbor anger, Foster fiendishness, one to another, far deep in your hearts.

First shalt thou be reconciled with him who opposeth thee,

Shalt be tranquil of spirit; then mayest thou offer thy treasures,

On God's altar give them - worthy they be of our good Lord,

Of the Heaven King worthy. For His kindness shall ye serve Him more,

For His favor follow God's will more, than most of the other Jews do,

If ye would someday own the Eternal Kingdom, See life without end. I shall still say unto you, As the old law once bade you:

An earl should never covet another man's wife, Seduce her with sin. This I also say unto you now, Soothy words: that a man's eye may quickly lead him

$$
\text { astray }
$$

Into murky misdeeds, if he letteth his mind be driven, So that he beginneth to yearn for her who may never be his.

Then he hath straightway done sin unto himself, Hath loaded hell-pangs upon his heart. If then a man's eye or again his right hand 
Or some limb lead him along the loathsome way, Then 'twould indeed be better for yon earl, Better for that bairn of men, that from his body he loose it,

Cast it from him afar, coming to Heaven without it Than that he flee with all to Inferno,

That with a whole body he go to the grounds of hell. Human frailty so willeth, that no man shall follow his friend,

Though a dear friend he be, if he driveth him on to sin,

Draweth him down to guilt. 'Tis no matter then, how close they do stand in the clan,

How mighty their kinship, if he maketh him murder, Draweth him down to misdeeds. Better he do this:

That he cast his friend far away from him

And lose all his kinsmen and have no love for a one, That he may alone mount on high

To the kingdom of Heaven, than in the pangs of hell Both would suffer broad punishments, too, And horrible pain.

\section{XVIII}

Here in the law it also

Standeth written with soothy words, so that ye may all understand it:

That all people should ever avoid perjury,

Nor themselves swear falsely, since that is great sin, Leading much folk astray along loathsome ways. Then I shall also say unto you, that no one should swear,

No child of man swear any such oath,

Neither by Heaven on high (since that is the Lord's throne)

Nor by the earth here below (since that is All-Wielder's 
Footstool so fair), nor should any child of the folk Swear by his own head, since he may turn not a single hair,

Either black or white, but as Holy God

Hath mightily marked it. Therefore the many, The earls should avoid every oath-word. He who oft

Sweareth becometh steadily worse, since no longer can he ward for himself.

Therefore I say unto you with soothy words

That ye shall never swear any stronger oaths, Mightier ones with men except as with My words

I most verily here do command you:

If a man hath trouble with another, let him speak the truth;

Say 'yea,' if it be so, confess that it is true;

Say 'nay,' if it be not, and let that be enough.

If a man sayeth more, much beyond that, It becometh a bad thing for the bairns of men,

So that earls, all disloyal, will not believe

One another's word. Then I also verily tell unto you:

As by the old law you were so bidden:

Whosoever taketh the eye of another man,

Looseneth it from his body, or some limb indeed -

That he shall pay to the person for the loss

With a like limb of his own. Now I give you this lesson:

Ye shall not wreak vengeance for deeds done wrong.

Instead shall ye suffer most humbly all things yourselves,

The pain and the wrong that people will do you here in this world.

Let each earl do unto another whatsoever is good and is useful,

If he so willeth, that the children of men

Do good unto him; that God will be mild unto him,

Mild unto each man who doeth the Master's will.

Respect ye the poor and divide ye your riches, Among those who are needy. Nor be ye troubled, if ye receive no thanks, 
No reward in this passing world. But well may ye hope That your Dear Master, your Mighty Liege,

Will reward you with gifts, grant you good pay

For what ye have done for your love of Him.

If thou wouldest give to good men all

Fair shining coins, and thinkest thereby

To reap a reward, how willest thou then have return from God,

Or largess here in the light? For these are brieflasting goods.

So it is for all that thou doest for others, For love of the land-folk - if thou thinkest to receive the like

In word and in work: why should the Wielder know thanks,

Since thou givest to them and gettest from them in return?

Give thou thy riches to the poor men, who give unto thee

No rewards in this world; and strive then for the Wielder's realm.

But act thou not loudly, when thou givest thy alms To the needy of men; but be thou meek all of mind,

Glad for God's thanks; for a goodly reward wilt thou take,

Find a fair return, where far longer

Thou shalt use it. That which thou givest with a pious heart,

And sharest in secret, is esteemed by our Lord.

Nor boast of thy giving - let no great lord do so either -

Lest through idle boasts the gift is made nought And forlornly lost. Before the eyes of the Lord Shalt thou receive thy reward for thy work right and good.

Also shall I bid thee, when thou bendest thy knee In prayer, begging help from the Lord, begging 
That He grant thee release from the loathsome thing, From sin and from shame, which ye yourselves Have wrongfully wrought - ask not before others Nor make it known to the many, lest men extol you And give praise unto you; and the prayer to your Lord You lose most forlornly for idle fame.

But if ye do ask help from your Lord on high, Praying most humbly to Him - that must ye surely here

$$
\text { do - }
$$

That your Battle-Lord befree you from sin,

Do ye so in the darkness: yet your Lord doth know, $\mathrm{He}$, Holy in Heaven, since nothing is hidden to Him, Neither of words nor of works. Thus will He make it, As ye have bidden of Him - if unto Him ye have bent Your knee, your hearts being pure." The heroes all rose,

The men stood gladly around God's Son,

The world-men to their will. They longed for such words,

Pondered and kept their peace. The people had need

To think over again all that the Holy Bairn Had told unto them on this first time, Had all clearly proclaimed. Then spoke one of the twelve;

Of the goodly men one began to ask of God's Bairn:

$\mathrm{XIX}$

"Master good," quoth he, "we are in need of Thy grace To work Thy will and Thy word as well, Best of All Bairns, and we bid Thee teach us To pray, Thy disciples, as doeth John, The dear Baptist, on every day,

Teaching his world-folk with words how to greet the Wielder,

To speak to their God. For Thy disciples do Thou the same. 
Reveal Thou the runes." Then the Ruler had ready His answer for them, the Son of the Lord, For them His good word. "If ye would greet God," quoth $\mathrm{He}$,

"With your words greet the Wielder, The King Full of Strength, speak ye then as I teach you:

Father of us, who art all Thy folk-bairns, Thou who art on high in the kingdom of Heaven, Hallowed Thy name here in every world, Thy kingdom come in strength and craft, Thy will be done over all the world;

As here on earth; so there above

On high in the kingdom of Heaven.

Give us each day, good Lord, Thy gracious guidance, Thy holy help, and absolve us, O Warder of Heaven, From the manifold mischief we do against mankind, Let not loathsome wights lead us astray, As is their will and as we are worthy; But help us against all our evil deeds. So shall ye bid Him, when ye bend for prayer, Ye men, with your words, that the Mighty Wielder Release you from the loathsomeness that is in all land-folk,

If ye then would forgive the land-folk all

Of their sins and their selfishness, such wrongs as they

Have done against you - The Great Wielding God will absolve you,

The Father forgive you your frequent faults

And your heavy sins. But if ye harden your hearts, Are not willed to absolve other earls, other men from their wrong,

Then Almighty God will not forgive you your grim sins, But ye shall receive from Him just reward, Payment most pain-filled throughout plenteous time, For all the unrightness ye have done against others 
In the light of this world, without that ye have willed

To make peace in your matters with the children of men

Before ye shall wander, $\mathrm{O}$ ye men, out of this world. Today I shall also tell you how ye shall bring My teachings to pass:

For if ye would indeed keep a fast

To make little your misdeeds, make it not known

To the many, but hide it from all; yet Almighty God knoweth well,

The Wielder, your will; if other world-bairns,

Other land-folk fail to laud you, yet lovely reward $\mathrm{He}$ will give,

Your Holy Father, in Heaven's kingdom,

Since ye have served Him, ye men, so humbly here,

So piously all 'mid the people. Unright possessions, $\mathrm{O}$ my earls, covet them not; but care for rewards above With All-Wielding God. That is a weightier thing Than if a man liveth tichly here on this earth, Winning the goods of this world. If ye would hear then

$$
\text { My word, }
$$

Gather ye not great treasures, neither silver nor gold

In this mid-world here, nor hoards of riches;

For it reddens with rust here, and robbers will steal it.

Worms gnaw it away; the garments wear threadbare, The gold-wealth is gone. Do ye good works And gather in Heaven a hoard far greater, Riches fairer by far. Your foe cannot rob you, Can take nothing from you. For treasures stand ready For you up yonder, as much as ye there Have gathered in Heaven riches and goods, Heroes, ye, through your hand-gifts. And keep ye steadfast your hearts

For this; for there lie the thoughts of men, Their minds and their hearts; there lieth the hoard, The goods all gathered. Nor is any man so greatly blessed, 
That both he may do in this broad, wide world: That on this earth he may live richly indeed In all of his world-lusts, yet thankfully serve AllWielding God

At the selfsame time: but he shall ever Forsake wholly one or the other, Either the lusts of the body or life everlasting. Therefore grieve ye not for your garments, but hold ye fast unto God,

Nor mourn in your minds, how on the morrow Ye may find eat and drink, or, ye aethlings, What weeds ye will wear; for All-Wielding God Knoweth the needs of them who now serve Him well, Following the will of their Liege. Why, by the winged birds

Ye may verily see it: they that are in this world Flitting about in their feather-dress. Though they have won no fortune,

Yet the Lord, our God, giveth to them each day Help against hunger. Ye may in your hearts

Eke gaze at the flowers, when ye think of your garments,

How fairly they are garbed, as they stand in the field

Brightly blowing. Nor did that warder of bastions, Solomon the King, who had costlier treasure, Greater gold-hoards than any had e'er gained, Had won more wealth, the choicest of weeds Still in this life, though he was lord of these lands

$$
\text { all - }
$$

He never found raiment as fair as this flower hath on,

Which here in the field standeth ready and fair, Lily with so lovely a bloom. The Wielder of Lands hath so garbed it

From the high fields of Heaven. But this folk is far dearer, 
The men mean far more, those whom He hath made in this land,

Wielding o'er them, as He willed. Therefore may ye not worry concerning your dress,

Grieve over your garments so much; God will give counsel,

Help from Heaven's meadow, if ye willingly serve for His favor,

Always yearn for God's kingdom; then act ye according to those, His good works.

Strive ye for right things. Then will our Rich Lord

Gift you with all goods indeed, if ye so willingly

$$
\text { go, }
$$

Following Him, as I tell unto you with soothy words.

\section{$\mathrm{XX}$}

Ye shall never speak an unjust, a wrong judgment

Over any man, or accuse him falsely;

For doom falleth over him, so that the cares full

$$
\text { well, }
$$

The worries wax large of him who did speak such words

Of wrong against others. Not a one of you

Shall give wrong measure to another man,

Being feloniously bent in buying or selling

While on this earth here; for to each earl will hap

Even as he hath done unto others - even there where he would dearly

Not see his sins. Eke must I say yet unto you Where ye must guard against the greatest of evils, Against wrong-doings many: Why wilt thou reproach

$$
\text { a man? }
$$

$\mathrm{He}$ is thy brother. Thou seest under his brow A wisp in his eye, but are not willing by one whit To think of the beam which thou hast in thy own, $A$ hard tree and heavy. Into thy heart let it 
First fall: how to remove it. Then wilt thy light shine forth,

Thine eyen will be opened. Thus mayest thou later Make better the sight of thy sweet friend, Heal it, lo, in his head. Let each in his heart, Each man in this mid-world, think more of his own misdeeds

Than he thinketh of the sins of another, The faults of a friend - and hath himself done far worse,

Far greater wrongs. If to himself he would do good, Then shall he first make himself free of all sin, Loose of all loathsome deeds. Later may he then with his teachings

Be a help to the people, when he knoweth himself to be pure

And safe from sin. Nor shalt thou strew

Thy sea-pearls down before swine, nor scatter thy jewels,

Nor thy neckband holy; for they will trample it now in the mire,

Besmirch it in sand. For they know nothing, the swine, of cleanness,

Of sea-pearls so fair. Here there are many such folk Who will not hear thy holy word

Nor follow God's teachings, and know of no good. They would far liefer have low, useless things, Have empty words, than the work and the will Of your Wielder and God. They are not worthy, That they hear your holy word. For in their hearts they do not think,

Do not want to learn it nor do it. Say ye nought of your words unto them,

Lest ye squander God's speech and many a spell.

Lose ye not your word 'mid the land-folk, who do not want to believe it,

The great and true word. Eke shall ye guard against 
The wiles of this folk, as ye wander, ye earls, through the land,

Lest the teachers of lies lead you astray

With words and with works. They come wearing such garbs,

To you wearing fairer jewels: but their hearts are wily.

They speak wise words, but their works are worth nought, The thoughts of these thanes. For ye know that thorns never grow

On the wineberry nor on that which is worthy, On the fairer fruits. Nor does a man gather figs From the hawthorn tree. Keep ye this truth in your hearts:

That the bad tree which standeth there in the earth Never giveth forth good fruit; and that God hath not shaped it,

That the good tree of the bairns of men bear bitter fruit;

But from every tree whatsoever there cometh forth only

Such fruit to this world as was born from the root, Either bright fruit or bitter. That is the feeling in the breasts,

In the hearts of so many of the kinfolk of man, Wherever each one of the earls showeth himself all openly,

Maketh known with his mouth of what mind he is, The thoughts in his heart; nor may he hide them ever; But from an evil man cometh unwise counsel, Words bitter and blameworthy, such as he hath in his breast,

Harboring them 'round his heart: here his thoughts become known,

His will along with his words; and his works follow, too.

There cometh from a good man an answer, gracious and clear, 
Wise in his wit, that he ever speaketh with words -

The man with his mouth; such words as he hath in his mind,

Hoarded round his heart. Thence cometh the Holy Gospel, That most Winsome Word, and his works shall thrive For the good of men, for many a thane, As indeed is his will, even as the Wielder

Did grant unto good men, God Almighty, The High Liege of Heaven, since without His will Neither with words nor with works can they do one whit

Of good in this world-garden here. Therefore all the bairns of mankind should most gladly

Believe in the strength and the might of this One Single Lord.

XXI

Here I must tell you, too that pathways twain

Lie in this light. Thereon the land-bairns

Must travel, the children of earth. One of the twain

Is a street broad and wide: much folk wandereth on it,

Of mankind so many; for their mind doth drive them The world-lust, these war-men. On the worse side It doth lead them, the landsmen, where they are lost, The heroes in hell fire; there it is swarthy and hot, Horrible within. Easily may the children of earth Travel thereto. Still in the end it availeth them not.

Then lieth again another and narrower path, A way in this world, on which do wander But few of the folk. The bairns of men follow it Ungladly, though it goeth on to God's kingdom, Leadeth all aethlings into eternal life.

But take ye the narrow one; though it be never so easy

For world-folk to wander on, it availeth well 
Whosoever trespasseth it; he hath bounteous pay, Long-lasting reward and life never ending, The dearest of doing. And do ye so pray

To your Lord, the Wielder, that this be the way

Ye follow forthwith, and going further along this path

Into God's realm. For He is ready ever

To give in return, if a man biddeth rightly, If the folk-bairns do ask him. Seek ye your Father, Which is in the kingdom unending. There can ye find Him

For your welfare eternal. Make ye known your travels At your Master's door; for you they may open, Heaven's portals unlock, so that to the holy light, To God's realm itself, now ye may go,

Seeing life everlasting. Lo, I shall say unto you, Tell you one token more truly for the earth-folk all, That every man whosoever keepeth $\mathrm{My}$ teachings Held in his heart, who thinketh of them in his mind, And worketh them in this world - he worketh indeed Like a wise man having great wit, A head that is clearer. And he chooseth his homestead On right fast ground, and upon a rock

He worketh the walls, where neither the wind

Nor the wave nor the water's stream can harm it a whit,

But it standeth there strong 'gainst all storms High on the rock, since right firmly it was

Set on the stone. From beneath, the spot holds it steady,

True and straight 'gainst the wind, that it cannot topple.

Thus doeth each man, who willeth not

To hear these, my teachings, or to carry them out:

He acteth indeed like the unwise earl,

Like the witless world-man, who on the water's shore, On the sand itself, would set up his great halled

house, 
Where the western wind and the waves of the stream, The tides of the sea do tear it, sand and grit cannot Hold it up 'gainst the flood, since it stood not fast, Firmly timbered in earth. So shall the work of each earl

Strive for this, each aethling who followeth My Word, Holdeth My holy commandments." In their hearts they began,

The many children of men, to wonder: they heard the Almighty God's

Love-filled lessons. In this land they were truly not wont

To hear such things being said ever before,

Either of words or of works. But wise men understood, That He so taught unto them words of great truth, The Liege of the Land-folk, since He, lo, had power Unlike unto others, who in earlier days

Were chosen to teach from the children of men From the clans themselves. Never had of Christ's words The like been heard 'mid the land-folk, when He set down His law

To the bairns on the mountain.

XXI I

He bade them do both:

Not only should they say and spread His word, How one should reach the realms of Heaven, The Farspreading Fiefdom; but first $\mathrm{He}$ did lend Unto them the power to heal the halt and the blind, The ills of the world-folk, their manifold weakness And terrible plagues; and He bade them, too, Never to garner money from any man

Or to take treasured pay. To them $\mathrm{He}$ did tell this: "Keep ye well in mind, how this wit and this wisdom were come unto you, And the Father of all Folk hath lent you the force. Ye need not buy it 
With goods nor pay for it with gold. Therefore be ye gracious unto men;

Mild in your hearts and ready to help,

Teaching the land-bairns long-lasting counsel,

Enduring deeds. Deal ye right heavily still with their wrongs,

With their swarthy sins. Let not silver nor gold

Be of such worth unto you, that ye would e'er own them,

Fair glimmering gold-pieces; for they will give you no joy,

Be useless to you. Ye shall own no more garments, My earls, no more weeds, than those which ye wear, Ye good men, to garb you, when ye do go forth Among the many. Ye shall not think of your meat, Not long of your body's food; for the folk shall feed Them that are teaching. That shall be of use, Which ye say to the folk - of right fair reward.

Worthy is the workman, that he be fed well, The man given meat, who shall care for so many, The souls of the folk, making firm the way For the ghosts to God's meadow. That is a greater thing,

That a man should make ready for the souls of the many,

Should keep them all for the kingdom of Heaven, Than that he careth for the bodies of folk

With meat, for the children of men. Therefore should mankind

Keep fondly and sweetly those who show them The way to Heaven's kingdom and hold the harm-doer, The Fiend far from them; who give them blame for their faults,

For their sins dire and swarthy. Now I shall send you Throughout the landscape, like a lamb among wolves. So shall ye fare 'mid the foe, amid world-folk many, Amid unlike men. Keep ye your minds toward them 
So clear and clever as the bright-colored worm, The slyly wise serpent, when it doth suspect

A deadly foe. Then men of the folk

Cannot lead you astray. Ye shall take care

Lest men turn away the thoughts of your mind

And destroy your will. Be ye wary of them,

Of their furtive deeds again like the dove;

Having toward all folk a simple heart,

Meekness of mind, so that no man can be cheated,

Be ever deceived by your deeds,

Led astray by your sins. Now shall ye fare

On your way with these tidings: much toil shall ye

bear

Amid the people and oppression together,

Much and varied, if in My name

Ye do teach the land-folk. Ye shall yet receive much of evil

From the people of world and still worse pain

For this, My right word; before the kingdoms of World Shall ye oft stand bound and suffer both

Mockery and scornful speech: but let not your spirits feel doubt,

Nor your souls ever err; nor need ye ever

Harbor care in your heart - when they call ye forth from the crowd,

Bid you go with them to the guest hall -

What ye will say unto them with your good words,

How ye will speak to them wisely; for success will come unto you,

Help come from Heaven, and the Holy Ghost will speak Mightily out of your mouth. Therefore dread ye not the hatred of men,

Fear not their fiendishness. For though they have power Over your life, may rob your body of breath, Slay you with swords - yet not a whit of your soul Can they e'er destroy. Dread ye All-Wielding God, Fear ye your Father. For Him gladly 
Do ye His commandment, for He hath might and power Over both, o'er the life of a man, o'er his body as well,

Yea, even o'er the soul itself. If for the sake of these teachings

Ye lose your life on the way, then in the light of God

Ye shall find it again, for the Father, The Holy Lord God, hath kept it in the kingdom of Heaven.

\section{$\mathrm{XXIII}$}

Not all will reach Heaven who here hail Me Protector, Their Master and Lord. There are many of them Who willingly kneel to the Liege every day, Calling on Him for help, but have other thoughts in their hearts,

Working dastardly deeds; they win no gain from their words.

But those may hasten toward Heaven's light, Go on to the kingdom of God, who gladly here Accomplish the work of the Wielder, and His will as well.

They need not call unto Him, their Master, with words so many,

Hailing Him for help, since All-Holy God,

Knoweth of every man the thoughts in his mind, His word and his will, and payeth him right for his work.

As ye fare on your way, let this be your worry And your task as well: to fulfill my tidings, As ye fare on your path, far o'er the landscape Through the wideness of world, where your ways will lead you,

The broad street to the borough: straightway seek ye the best 
Men among the multitude, and make ye known unto them

With words of truth what lieth in your minds. If they be worthy

Of this: that they gladly give help to your good works

With pureness of heart, then may ye dwell in the house

With them as ye will, rewarding them well:

Pay them with goodness - give them to God Himself

With your words, foretelling the Wielder's sure peace, The holy help of the King of Heaven.

Yet if they cannot become blessed

By their own deeds, cannot do your works, Carry out your message: then leave ye these men, Fare forth from this folk; and your peace will fare forth with you

Once more on the very same way; and leave ye them in their wickedness,

In their works of sin, and seek for yourselves another way,

A much larger gathering; nor leave ye of dust one single grain

To follow your feet from there, where one hath received you unfairly;

But shake ye that dust from your shoes, so that it becometh a shame,

A witness there to the world-folk, that their work is worth nought.

Then I tell unto you and in truth: that when this world doth come to its end

And that Famous Day fareth over all mankind, That the city of Sodom, which for its sins

Was felled to its fundament by the force of the flame,

The power of fire - it will have more peace, A milder protector than shall have those men Who cast you aside, were unwilling to accomplish your word. 
Whosoever receiveth you with a pious soul And mildness of mind, he hath done so for Me, Hath accomplished My will, accepted All-Wielding God, Your Mighty Father, Master of Mankind,

The Rich Giver of Truth, who knoweth all right.

The Wielder Himself doth know and reward the work

Of each earthling, if to any man ever

He doeth some good for the love of God:

Willingly giveth water to drink

That the needy man is healed of his thirst

From the cold well-spring. The word will come true.

It will never fail, that he find fair

Reward in the eyes of God, receive recompense

Of many a sort for that which he doeth in God's sweet love.

But whosoever of the bairns of men doth deny Me here,

Of the warriors before the host, in Heaven I shall likewise do unto him

Far above before the All-Wielding Father and before the strength of His angels,

Before their multitude. Whosoever of the children of men

Doth not with his words deny Me here in this world, But before the kinship of men confesses he is My disciple,

Him will I vouch for before God's very eyen, Before the Father of All, there where so many folk Wend their way to the All-Wielder To justify their deeds before the Great Judge.

There will I be,

As is meet, a mild Protector for whosoever hearkeneth unto $\mathrm{Me}$,

Who hath heard My word, and accomplished the work, Which I have commanded of you up here on the mountain." So the Son of the Wielder verily taught the worldfolk

How they should work God's love. Then He sent them away, 
The men of His host, each to his own home.

They had heard the Word, the Heaven King's holy Spell.

Whosoever in this world was wiser in word and in deed,

Many of mankind over the face of this mid-world, Smarter in speech - he heard the Spell

Which the Richest of Men spoke on the mountain.

\section{XXIV}

It was three nights later, that the Lord of the Land-folk

Went into Galilee-land there to a wedding feast:

God's Bairn had been bidden. A bride would be given, A most lovely maid. Mary was there, The Mighty One's mother. The Lord of the Many, God's Own Bairn, did go with His followers To the high house, where the hordes were drinking, The Jews in the guest-hall. He did go to the feast, Made known to the guests, that He had God's power, Help from the Heaven-Father and the Holy Ghost, The All-Wielder's wisdom. The warriors were blithe, The land-folk together loud in their joy, Glad-hearted the guests. The grooms went about Pouring from pitchers; the pure wine they Carried in jugs and in cups. The crowd's tumult Was gay in the great hall, when the folk began, one 'mid the other,

To feel their best blitheness; there on the benches In rapture were they, when the wine ran out, The fruit drink of the folk - for nought was there left,

No drop in the house, which to the hordes The butlers might bear, when all of the vessels Were empty of mead. 'Twas not long after that That the fairest of ladies did find this out, 
The mother of Christ. She went to speak to her Kin, To her Son Himself; she said with her words That the host of the house had no more of wine, Hight the Holy Christ, that He find some help For the joy of the many. There again God's Mighty

\section{Bairn}

Had ready His word: with His mother He spoke:

"What doth the mead of these men," quoth $\mathrm{He}$, "mean to $\mathrm{Me}$,

The wine of this world-folk? Why, O goodwife, speaketh thou

So much, admonishing Me before these many?

My time is not come yet!" Yet she still trusted well

Deep in her heart, the Holy Maid,

That the Wielder's Bairn - even after these words -

Would help indeed, the Best of All Healers.

Then the sweetest of ladies hight all the servants,

The butlers and cup-bearers who had here been serving,

That they omit not a whit either of words or of works

Of that which the Holy Christ would hight them do

For the people there. The pots all stood empty,

Stone vessels six. Quite softly He bade them -

God's Mighty Bairn - so that many a man

Was verily all unaware what $\mathrm{He}$ said with His words.

He hight that the butlers should fill the barrels,

The cup-bearers there, with clearest water; with His fingers $\mathrm{He}$ blessed it,

With His hands turned it to wine; and He hight the vessels be filled,

The pitchers be poured from; and He spoke to the servants,

Hight that they give with their hands to the foremost guest

Who was here at the feast: for him pour a fulsome jug, Who next to the host was the noblest there. When he now drank the wine,

He was loathe to keep still; but before the many he spake 
To the bridegroom then; quoth that the best mead should have been brought,

The finest of the fruit-wines given first to the earls

At once at the wedding. "So is a man's wit Awakened by the wine, and he waxeth blithe, Maketh merry with drink. Then mayest thou bring on The worser wines. That is the way of this folk.

But most strangely indeed hast thou marked thy hostship

Among the multitude here; thou hast hight thy serving men,

Thy butlers and cup-bearers bring out at the banquet

Of all the wines the very worst forsooth, Serving that first at the feast. Now that thy guests are filled,

The dear banqueteers are already most drunk, The folk feeling merry, thou hightest brought forth The loveliest of all wines which I ever saw lifted Anywhere in this earth-light. Thou shouldst have given that earlier,

Have served us sooner. Such thanks wouldst thou then Have garnered from all the good men." Many a thane grew

Aware after these words - as soon as they had drunk of the wine -

That here in the house the Holy Christ Had revealed a token. They trusted thereafter The more in His rule: that He had God's might To wield in this world. So it came widely known Over Galilee-land to the Jewish folk That the Son of the Lord had Himself turned The water to wine. That was of His wonders The first which He showed as a sign to the Jewish folk,

As a token in Galilee-land. Nor may anyone tell 
Nor say forsooth, what hath happed since then

In the way of wonders among the folk; for All-Wielding

Christ

Told His teachings unto the people of Jews

The livelong day in the name of Lord God,

Promised the kingdom of Heaven; with His words protected them, too,

From the press of hell. Hight that they should seek the wardship of God

And eternal life. There is the light of the souls, The Lord's life ever joyous, the glow of the day, The good glory of God. There many guests

Dwell to His will, who here have thought well How best they should keep it, the Heaven-King's commandment.

$\mathrm{XXV}$

With His followers He went forth from the feast, Christ to Capernaum, the Richest of Kings, To that famous town. Much folk was assembled, Was gathered around Him, men of good stock A blessed following it was. They wanted to hear His word,

Which was sweet and holy. There came toward Him a centurion;

A good man, he approached Him and bade Him most earnestly,

That the Holy One help him. Quoth that at home He had long had a man lame and sickly, In his family a feeble one, "For I tell Thee no one

Can heal him with hands. Now I have need of Thy help, Good Lord, my Liege." Then spoke the Peace-Bairn of God

And straightway Himself did say unto him,

Quoth that He would come and save his young kin From his direst need. Then came nearer 
The man from the multitude to speak to the Mighty Christ,

To exchange words with Him. "I am not worthy," quoth he,

"Good Lord, my Liege, that Thou wouldst come to my house -

Wouldst seek out my dwelling, for I am a sinful man With my words and my works. I believe Thou wieldest might,

Canst work his healing here in this place, My Wielder and Lord; if Thou speakest Thy word, $\mathrm{He}$ is cured of his sickness; clean and bright shining Doth his body become, if Thou wilt but give him Thy help.

I am a man holding office and have wealth enough, Have gained goodly things; though I stand governed By an aethling king, yet have I of earls quite a following,

Loyal warriors in arms, who listen alone unto me, Who leave of word or of work not a whit undone Of that which I bid them do here in the land;

But they fare forth and finish it, do return to their master,

Being obedient to me, their lord. Though I do own broad

Spreading goods in my house, have servants enough, War-minded men, still may I not dare

To bid Thee, God's Bairn so Holy, to enter my building,

To seek out my dwelling, since I am so sinful, So mindful, my Lord, of my misdeeds." Then spoke once more All-Wielding Christ,

The Finest of Men, to His followers; quoth that never had $\mathrm{He}$ found

Anywhere 'mongst the Jews, among the offspring of Israel,

The like of this man in the landscape; one who believed 
More deeply in God, more purely in Heaven - "Now may

Ye hear, ye too, what I say at this time with words of truth:

That much foreign folk from the East and the West,

Many clans of mankind shall come together,

God's holy folk in the Heavenly Kingdom:

They will rest right well in the lap of Abraham,

Of Isaac himself and of Jacob, good men all, and enjoy

Goods and good will and a winsome life

And the great light with God. But lo, many Jews,

The sons of this realm will then be robbed,

Be sundered from such splendor, and shall have to lie

In the darkest dales in the farthest distance of all.

There one can hear the heroes lamenting

And gnashing their teeth in terror and pain.

There is furious rage and a hungry fire

And the hard pangs of hell, hot and thirsty,

Swarthy might, never ending, as payment for sin,

For wretched wrong-doing, to all who have not willed to rid

Themselves of their wrongs before they relinquish the light,

Wend their way from this world. Now if 'tis thy will, Thou mayest go home. In thy house thou wilt find hale

And sound the child-young man: he will be joyous of mind.

The bairn hath been healed; even so as thou badest Me, All hath been done, even as thou hast belief Firm fixed in thy heart." Then to the Heaven-King, To the All-Wielding Child of God the centurion gave thanks

Before all the folk for this, that He had helped him thus in his anguish. 
It was all worked, even as he had wished it And most blessed indeed: he did go on his way, Went as he willed, where he had ownership,

A house and a home. There he found hale his bairn, The child-young man. Christ's word was accomplished, for He had

The might to show forth tokens, so that no man could tell,

Over the earth could reckon, that He through His own power,

Through His strength had made miracles on this midworld here,

Accomplished such marvels. For all things stand in

Both Heaven and earth. His might,

XXVI

Then the Holy Christ bethought Him

To fare on farther. For the bairns of the folk The Master of All, the Almighty, the Good, Every day did accomplish deeds dear and good; With words taught God's will to the people, had always Followers aplenty about Him, blessed folk of God, A mighty crowd of men, come from many peoples, A holy army and host. He was good in His help, Mild to the men. Then He came with the many: Now the Bairn of God with a noisy crowd came to Nain, The Savior to the high-standing city. There His name Would become famed among men. There mightily The Saving Christ walked along until He came closer, The Best of All Healers. They saw folk bringing a body -

They came carrying a corpse without life.

On a bier they bore it through the gates of the bastion, A child-young man. The mother did follow, Her heart being heavy; herself did she beat with her hands, 
Bewailed and lamented the death of her bairn Unhappy woman was she - it was her only child. She was a widow, in this world had no joy Except this one son, whom Weird had now taken. She had lost all things, had lost joy and happiness; And now fate, ill-famed, had robbed her of him. Many people did follow,

A crowd of the burghers, as they carried the bier, The young man to his grave. There the Son of God, The Mighty grew mild; and to the mother He spoke; Hight the widow leave off with her weeping, Nor care for her child; "Thou shalt see here the strength,

The work of the Wielder: thy will shall be granted thee,

Comfort in front of the folk: from now on thy spirit May not bemoan thy bairn." Then He went to the bier, He Himself did touch it, the Son of the Lord, With His holy hands and to the hero He spoke, Hight this child, all too young, to stand up, hight him

Arise from his rest. Right away the youth

Did sit up, the bairn on the bier; and into his breast came

His soul through the strength of God; and he spoke unto them,

The man to his kith. Christ commended him then to his mother,

The Holy One into her hands. Her heart was consoled, Happy the woman, since to her so much grace had happed.

She fell to Christ's feet and praised Him, the FolkLord,

Master, before all the multitude, since He had here helped

Her loved one to live 'gainst the working of Weird.

Well she knew that He was

The Mighty Lord, the Holy, who governed the Heaven, who could help so many 
Of earthlings all. Then many began to attend

The wonder, which had come to pass there 'mid the folk:

quoth that The Wielder Himself,

The Mighty, had come to teach them, the many, that $\mathrm{He}$

had sent

A prophet, most wonderous, to the kingdom of world; one who did His will.

Then truly many an earl was taken by terror,

The folk full of fear, for they saw him again

Alive and seeing the light of day; him whom death had but lately taken,

Stretched low on his sick-bed. Again he was sound, The young kin quickened; and soon this did spread To the heirs of all Israel. And when evening came, There were gathered about many sick men together, The halt and the lame of hand - whosoever was here

And lived 'mid the land-folk; they were led to the place,

Were come to the Christ, who through His strength and His craft

Helped them and healed them and sent them hale from the place

To wend where they willed. Therefore should one praise His words,

The Mighty Minder of all mankind,

Of whatsoever land-folk verily believeth

In His word and His work.

XXVII

There were come so many

From all the foreign folk for the glory of Christ, For His mighty guardianship. There onto a sea God's Son

Wished to go with His vassals - 'twas on Galilee's borders -

The Wielder onto a wave-tide. There $\mathrm{He}$ willed that the other folk 
Go wandering ahead, and He went with a few Into a small ship, the Savior Christ, Way-weary, to sleep. The weather-wise men Raised high the sail, let the wind drive the sloop Over the sea-tide, until they did come to the center, The Wielder there with His vassals. There began the force of the weather;

The storm-wind rose, the waves waxed high, Swarthy clouds swung down in between: the sea was astir,

Wind battled water; the men were worried.

The sea was so angry, not a man expected

To live any longer. The Land-Warden they then

Awakened with their words. They told unto Him of the weather's strength;

They bade saving Christ to be gracious and kind, to help

'Gainst the waters. "Else will we die, Martyred here in the sea." Then the Good Son of God Arose, Himself from His sleep. To His disciples $\mathrm{He}$ spoke,

Bade them not to dread the weather's battle one bit.

"Why art ye so fearful?" quoth He. "Are your hearts not yet firm,

Your belief yet so little. 'Twill not be long now Then the stream shall become stiller

And the weather all winsome." Then He spoke to the wind,

And to the sea itself. And He said unto them Both, that they should grow still. And they hearkened to His bidding,

To the Wielder's word. The weather grew calm, The flood became fair. There the folk around Him, The world-men did wonder, and with their words some did speak

What a Mighty One this Man was indeed, That the wind and the wave would heed His word, Both doing His bidding. The Bairn of God 
Had there saved them from need. The sloop sailed on farther,

The high-horned ship. The heroes did come, The leaders, to land. They all lauded God

And praised His great power. Then many people did come

To the Son of God. He received them most gladly, Whosoever sought help with a clear, pure heart. He did teach them to believe, and lo, their bodies He healed with His hands; though a man were hard And piteously pressed with plagues through Satan's Wily followers, though the force of the Fiend Held him fast in his hands, had destroyed his heart And his wit as well, that he went about

Mad among mankind; yet Mighty Christ always, The Healer, gave him back his life, if he were come to His hands,

Drove the devils hence with the power of God, With words of truth, and returned him his wit, Let him be healed against the haters, Gave him peace 'gainst the foe; and they went forth, Each into his own land, whichever he loved the most.

XXVIII

So our Dear Lord's Son did on each day God's work with His followers. But the Jews had no faith,

Believed not at all in the largeness of His strength:

That He was the All-Wielder over all things, Of lands and of people. Their reward is still lasting:

'Tis farflung exile, since they acted so evilly

'Gainst the Lord's Son Himself. With His retainers $\mathrm{He}$ soon went

Again into Galilee-land; He did go with His friends, God's own Bairn, to where $\mathrm{He}$ was born, Where as a young child He had waxed with His kin, 
$\mathrm{He}$, the Healer All Holy. Around Him a host, A great crowd did throng. There was many a thane So blessed 'mid the crowd. There some carried a sick man,

Certain earls in their arms. Before Christ's eyen they would

Bring him, before God's Bairn. Betterment he needed, Needed Heaven's Wielder to heal him indeed,

The Minder of Men. For many a day

He had been lamed of limb. Little could he

Govern his body at all. There were such great numbers

That they could not bring him before God's Bairn,

Could not press through the people to tell Him the plight

Of this poor, sick man. There He hied Himself within, To the hall, All Healing Christ - a great crowd was around Him,

A multitude of mankind. There the men who had so long

Carried with them the weak-limbed cripple

Began to speak how they might bear him on the bed before God's Bairn,

Through the world-folk within, so that Wielding Christ

Would see him Himself. So his servants went,

With their hands they did lift him, climbed high on the house,

Slit open the hall from the roof above, and with

$$
\text { ropes }
$$

Let him down in the building where the Rich Lord was, The Strongest of Kings. When He saw him coming Through the house's rafters, right well He knew from the hearts,

From the minds of these men, that mighty indeed Was their faith in Him. And so spoke He before all the folk,

Quoth that He would absolve the sick man from sin. In answer to this the people did speak, Rage-hardened Jews, quoth how could it be so: 
God alone can forgive works of crime, The world's All-Wielder. His word He had ready, God's Mighty Bairn. "I make manifest," quoth He, "in this man

Who lieth so ill here in this large hall -

Most grievously pained - that I have the power

To forgive the sins and to heal the sick man

Without even touching My hand to him."

Then our Mighty Lord admonished the man

Who lay there lame to rise there before the land-folk, To stand up hale. And He hight him take on his shoulders, On his back his bedding; and he did our Lord's bidding, Straightway before the assemblage, and went away sound, Hale from the house. Then many a heathen, Many a world-man did wonder, quoth that the Wielder Himself,

Surely God the Almighty had given unto Him

More splendid might than unto any man's son,

The skill and the strength; still they would not acknowledge,

That folk of the Jews, that He was God, Nor believed they His lesson, but struggled evilly with Him,

Fought against His word. For this they have won weary care,

Reaped a grievous return; and right long will that last For those who hear not the Heaven-King's teachings, The lesson of Christ, which is proclaimed over all, Wide and far in the world; and He let them all see His work,

Each day and every look on His deeds, Hear His holy word, which He spoke for the help Of the bairns of mankind. And so many and mighty A token He showed, that they trusted Him better, Believed in His word. So many a body He unbound from ills baleful and granted them betterment, 
Gave life to those destined to die, even if The hero was on hell's path already. The Healer Himself did so -

Christ through His might and His power quickened even the dead after death,

Let them further enjoy the winsomeness here in the world.

\section{$\mathrm{XXIX}$}

So healed He the halt and the lame of hand, Made better the blind, let them see the bright light, See Heaven's splendor; absolved them from sin, The world-men from wickedness. But the Jews grew no better,

This loathsome land-folk, in their belief

In the Holy Christ; but they were hardened of heart, Strove very strongly against Him, wanted not to perceive They were well ensnared by the devil's will, This folk through its faith; for He was not idle, The Son of the Lord; but with His words He said unto them

How they could gain the kingdom of Heaven; And through all the land $\mathrm{He}$ did teach; a multitude $\mathrm{He}$ did turn

Unto Him with His words, so that many a world-man, A great crowd of folk, did follow Him. And in figures God's Bairn spoke unto them things which in their breast they could not perceive

Nor grasp in their hearts, till the Holy Christ With open words willed to speak

To all people through His power and strength, And make clear what He meant. A mighty crowd, A very large one, thronged 'round Him. They longed

$$
\text { greatly }
$$

To hear the true word of the King of Heaven.

On the shores of the sea by the water He stood. 
Because of the great crowd, He cared not to proclaim

His lesson to His thanes there on the land;

But the Good One did go - and His disciples with Him all gladly -

The Peace-Bairn of God did go to a water

Unto a ship, hight that it shove off

Further from the land so that the folk,

The crowd, could not throng quite so close. Many

a thane,

Much world-folk stood by the water, where All-Wielding Christ

Did reveal His lesson to the land-folk there.

"Lo, I may say unto you," quoth He, "My disciples, How an earl began to sow good grain

In the soil with his hands. Some fell on hard stones

From above, and the grains had not earth enough

In which to grow rightly and send down roots, To sprout and cleave fast. And that corn was lost, That lay on those rocks. Some fell on the land,

On excellent soil. This soon began

To wax winsomely tall and take root right well; And most merrily it grew. The land was so good, So fruitful its kind. Again, some had fallen On a stiff, hard street, where steps did tread, The hoofbeats of horses and the feet of heroes. There was soil for them and indeed they sprouted, Began to wax on the way, but the walking of men did kill them,

The wayfaring of folk; and the flying birds picked them up,

So that they were not one whit of use To the owner there, those that did fall on the way. Some fell on that day where there stood so many Thickets of thorn. There was soil there for them, And they came up, they sprouted and cleaved; but weeds

Came between and kept them from growing. The cover 
Of forest spread out before them, and they could not grow fruitful,

Since the thornbrush thronged all around them."

Christ's disciples did sit and were silent all,

The word-wise thanes. For they wondered muchly

With what goodly pictures the Bairn of God

Would begin to say such a true and wise spell.

Then one of the earls began to ask

The Beloved Lord, bent low before Him

Most humbly indeed. "Why," quoth he, "Thou hast might

Both in Heaven and on earth, Holy Master,

Above and beneath. Beest Thou All-Wielder

Over the souls of men, and we Thy disciples,

Given to Thee with all our hearts, O Lord most Good.

If that be Thy will, let us hear Thy good word,

That we can proclaim it to all Christian folk.

We know indeed that upon Thy words

Follow true parables; and a need, most great, is in

us,

That in this land, here with Thee, we may teach

Thy word and Thy work - since from such wisdom it cometh."

$\mathrm{XXX}$

Then the Best of All Men spoke in answer to them.

"I did not mean," quoth He, "to disguise My deeds

In any way, either my words or my works; but ye

shall know all,

Ye disciples Mine; for unto you hath He granted,

The Wielder of Worlds, that ye may well know

In your hearts and your minds the mysteries of

Heaven.

Yet one must give unto others the commandments of God

With pictures in words. Now will I tell you

Most truly what I mean indeed, so that ye may better 
Understand my teachings over all the landscape. The seed which I spoke of is the Word of Himself, The Holy Scripture of the King of Heaven, As one should spread it o'er the mid-earth here, Wide in this world. World-folk, at heart, Men are most different; some are of such mind, So hard of spirit and evil of heart, That it seemeth not worth their while to act by your words

Or to be so willed to accomplish My teachings; But My lessons all are indeed lost unto them, And the commandments of God and the teachings of you, My men,

On these evil folk; as I earlier said unto you, That the corn did wither, which could not there Strike root with its sprouts upon the stones. So all will be lost, the speech of the aethling, The message of God - whatsoever one telleth To an evil man; and he chooseth the path, The way on the left, on the worse hand to God's displeasure,

To the foe of the folk and the onslaught of fire And the devil's joy. From that day on

He shall heat the broad flames with the heart in his breast.

Nonetheless in this land shall ye spread My lesson, Proclaim it with words, if there be many people, Such earls on this earth. Yet another man still may exist

Who is young and clever and hath kindness of heart, Is wise in his speech, understandeth your spell, Pondereth it in his heart and heareth it with his ears

Very zealouly indeed; and stepping closer, Accepteth in his heart the bidding of God, Learning and carrying it out. If his belief is so good, 
He will then wonder how he can woo another, A wrong-doing man; so that his mind be filled With a loyalty clear for the King of Heaven. The bidding of God groweth broad in his bosom, The willing belief, even as on the land The grain doeth with its sprouts, when it hath right ground,

Good soil to suit it, and the changing of weather The rain and the sun, so that it hath its right.

So doeth the teaching of God in a good-souled man Through the day and night; and the devil stayeth far, The wicked wight; and the word of God Is nearer to him in the nights and the days, So that it causeth him to accomplish both This lesson is a blessing to the bairns of the land That which cometh from his mouth, and the man becometh of God.

So hath he bought with his heart in this hour of world A piece of Heaven's kingdom, the greatest possession. Into God's power he fareth, freed from wrong deeds.

\section{Faithfulness}

Is so good for each man. No treasure of gold Is like unto belief. Henceforth teach ye the lesson

Mildly to mankind. These are so varied of mind, The heroes of men; some have hard strife, An evil will and a wavering spirit.

They are full of deceptions and deeds of wrong. As one beginneth to think, as he standeth there Among the crowd, and harkeneth with great care To the teachings of God; then he thinketh he would gladly

Henceforth carry them out. Then the teachings of God Begin to cleave to his heart, until there come once more

Through his hands possessions and proud wealth of others;

Then loathsome wights lead him astray, 
And avarice doth seize him again

And killeth now his belief: thus was it little use unto him

That he ever thought in his heart, if he willed not hold it.

Even so is the waxing which began on the wayside,

Grew fair on the land; there the footsteps of folk could destroy it again.

So mighty sins in the soul of that man

Do unto God's teachings, if he take not heed.

Otherwise will they follow him down far to the bottom,

To the heart of hell. To the King of Heaven

$\mathrm{He}$ is of no further help, but the Fiend

Will punish him direly with pain. Likewise repair ye forth,

Teaching with words in the world; I will know the hearts of the folk,

Many differences of mind among mankind,

Their varied ways... ${ }^{1}$

Some have turned their spirits entirely to this

And come more to keep their hoard than to work the Heaven King's

Will down on earth. Therefore it waxeth not God's holy commandment - though it may cleave there And send forth roots. But riches do crowd it, Even as the weeds and the thorn entangle the corn And keep it from waxing: so doeth wealth to a man. He fettereth his heart so that he here pondereth not, The man in his mind, what he needeth most: How he will work that indeed as long as he liveth here in this world,

That he have Heaven's Kingdom, through his High Lord's grace,

Days everlasting and endless riches, As no man knoweth them here in the world. Never

1 Lacuna in MS. 
May he think so widely, the thane in his mind, Nor may the heart of a man hold it and grasp it To know most verily what good All-Wielding God Hath made ready so that for each man All standeth open - for each who loveth Him well And hath kept his soul so turned ever That he will here enter the light of the Lord."

$\mathrm{XXXI}$

So He taught them with words; and a wide crowd Stood 'round God's Bairn and busily hearkened, As He told with His words the way of the world through His parables many.

He told how an aethling once sowed an acre Of fine corn with his hands, good grain in the field. He wanted to gain the most winsome of growths, The fairest of fruits. But his foe did follow him

With treacherous mind; and with tares he sowed over the top,

With the worst of weeds. And they waxed there both, The corn and the tares. So came along

The husbandmen to the house, and told this to him, to their lord,

The thanes to the warden with honest words.

"Why, thou didst sow fine grain, master most good,

Unmixed on this acre. Yet each earl can see

Nought but weeds are waxing. Well, how can that be?" There spake again the aethling, the man to his earls, To his vassals the warder; quoth that he could well understand

That an unfriendly man had sown after him, That his foe had slyly sown weeds: "These fruits he begrudgeth me so,

That for me he hath stamped out this growth." Then to him spoke again

His friends, his followers, quoth that they would fare there, 
Go with force and would uproot the growth,

The weeds with their hands. Then their lord spake once more unto them:

"I would not that ye weed them," quoth he, "since

ye cannot avoid it,

Cannot prevent in your passing, though ye do it ungladly,

That ye kill young sprouts and corn aplenty,

Fell them under your feet. Henceforth let both

Wax together, till the harvest doth come

And the fruits are ripe in the fields,

Ready all on the acre. Then to that acre

Let us fare; with our hands fetch and gather the fair

$$
\text { grain, }
$$

The pure corn cleanly together, keep it stored in my halls,

So that not a speck can be spoiled. Take ye the weeds

Bind them in bundles and cast them into bitter fire.

Let the hot flames fetch them away,

The insatiable blaze." Then many an earl stood silent,

Many a thane in thought, pondering what the Glorious

Christ,

The Mighty, the Master of Men, could mean

And proclaim with His parables, the Most Priceless of

Bairns.

Most eagerly they bade their Master Good

To unlock the lesson, so that the land-folk about

Might henceforth hear it, His Holy Word. Their Lord here replied unto them -

Famed, Mighty Christ. " "This is," quoth He, "the Son of Man.

I myself am He Who there soweth; and these blessed men

Who hearken closely to me are the fair, clean corn.

They do work my will. This world is the field,

The broad farmland of the bairns of mankind;

And it is Satan himself who soweth after $\mathrm{Me}$

Such loathsome lessons. Of the land-folk so many, 
Of the people, so many hath he ruined, so that they wreak much wrong,

Working bis will. Yet they shall wax henceforth, Those men who are damned, even as do the good, Until the Judgment Day journeyeth on over them The end of the world. Each field then, each acre, Hath ripened all in the realm. And the children of men will rightly

Finish their fore-ordained fate. Earth will explode:

That is the broadest of harvests; and the Bright, Glorious Lord

Cometh above with the force of His angels; all folk shall gather,

Who have seen this light; and shall receive such reward, Both evil and good. Then God's angels go forth, Heaven's holy warders; and from the host

They shall seek out the sinless men; bring such men to beauty unending,

To the high light of Heaven; throwing the others to the grounds of hell,

To the surging fire, those who were forfeited.

There in bonds shall they suffer the bitter fire, The awful pain, while the others have riches In the kingdom of Heaven, surely giving light on high, Like unto white suns. Such rewards will they reap, Those men for their murderous deeds. Whosoever hath wit in his mind,

Thoughts in his heart, who would like to hear An earl with his ears - let that indeed be his care In his innermost heart, how he will face God the Richest on that renowned Day of Reckoning Of all the words and the works which he hath done in this world.

That is the most awful of all things indeed, The most fearful for the folk-bairns: that they must speak face to face with the Lord -

The men to their Master Good; there would each man 
And all most gladly be rid of his misdeeds, His ugly sins. Instead each one should take care earlier,

All the land-folk ever, before they must leave this light,

That they will have this eternal honor,

The high kingdom of Heaven and God's holy grace."

\section{XXXII}

So I discovered that He Himself, the Son of God, The Best of All Bairns told boldly in parables What there might be in the kingdom of world Among the races of heroes like unto the kingdom of Heaven;

Quoth that that which is little often waxeth lighter, So that it riseth on high, "So doeth the realm of Heaven.

That is ever more than any one man

Can envision here in this world. Also his work is like unto him:

That a man doth cast his nets into the sea,

Doth fish in the flood, and findeth both in his

$$
\text { catch - }
$$

Both evil and good - toweth both to the shore,

Getteth them both onto land, throweth the good on the grit,

Letteth the other return again into the sea, To the wide waves there. So doeth All-Wielding God On the best-known Day to the bairns of men. He bringeth the earthlings together all, Picketh then the pure ones for the kingdom of Heaven, Letteth the damned ones fare down to the bottom, To the fire of hell. Nor doth any hero of men Know how to counter the pain, which a person, A man of the folk, must suffer in infernal hell. Likewise can no man find a like reward, 
Either in riches or rejoicing, as the Right-Wielder granteth,

God Himself doth give to each man of goodness Who here keepeth himself so, so that he may enter the kingdom

Of Heaven and the light that is long, long lasting."

So with His wiles He did teach them. And the folk wended hence

From all Galilee-land to see God's Bairn.

They did so for the wonderment, whence such words came to Him,

So sagely spoken; that He could say unto them

The Gospel of God in such goodly fashion,

Could quote it so cleverly. "He is of these clans here," quoth they,

"This man through His kinships. Here is His mother among us,

A wife 'mid this world-folk. What, we all know them here.

His kinships are all in our ken; and all of his clans

as well.

He waxed 'mid this world-folk. Whence cometh such wit, Whence cometh more might than hath any other man?" So the men of the land did scorn Him and spoke on their silly words,

Despised Him, Who was holy, and would not hear The Gospel of God. Because of their great disbelief He would not make known His parables many, His shining tokens, for He saw the doubt of their minds, Their wrath-harboring hearts: that here never were Men so grim-minded 'mongst the Jews as were in Galileeland,

So hard of heart. Though He was the Holy Christ As God's Bairn was He born - they would never believe Nor piously receive the gospel. Now the people began

$$
\text { to plot, }
$$

The world-men to wonder, how worst of all

They might torment Mighty Christ. They hight their men, 
Their companions come together; they would accuse Him Gladly, the Son of God, accuse Him of sin

With an evil design; for there was no longing in them

For the Word, for the wise spell; but they began to speak 'mongst themselves,

How they might cast Him, the Clever and Strong, over a cliff,

Over a mountain's wall. The Wielder's Bairn they would kill,

Loose Him from life. Along with His folk

He fared happily forth. There was no fear in His heart,

For He knew full well that the Jewish folk,

That the children of men could do Him no harm

Because of His godliness e'er His time was come,

Do no loathsome deeds. But with that folk He did go,

Climbed high up a cliff, till they came to the place

Where they planned to cast Him from the craggy wall, Fell Him to earth, that He would forfeit His life,

That His age be ended. But the minds of the earls

Up high on that mountain, the bitter thoughts

Of those Jews did pass, so that not a one possessed such grimness of mind,

Such wrathful spirit, that he could recognize Christ,

The Son of the Wielder. But to no one was He known,

No one could recognize Him. So could He stand 'mid the crowd,

Walk along 'mongst the multitude there,

Fare forth through the folk. He found peace for Himself, Found protection 'gainst the host, and went forth through their midst,

Through the folk of the foe. He fared, since He willed so, Into a wilderness, the Son of the Wielder, The Strongest of Kings: He had the power to choose Where in this land He would liefer be, Where in this world He would tarry. 


\section{On another way went John}

With his disciples, the servant of God.

He taught the land-folk long-lasting counsel:

Said that they should do good, forsaking all sin,

All misdeeds and murderous works. To many he was most

$$
\text { dear, }
$$

To good men and kind. There he sought the king of the Jews,

The leader of his hosts in his house. Herod he was

$$
\text { hight }
$$

For his elders, this over-proud man.

His bride did bide with him - she, who had been his

$$
\text { brother's, }
$$

His wife in his wide home, until he went forth

And changed his abode. Then came the king,

Took this woman for his wife. There were children

already,

The bairns of his brother. He began to blame her John the Good - said it was repulsive to God, To the Wielder Himself, for any world-man to do so:

To take in his bed the bride of his brother

And have her as wife. "If thou would'st hear me,

Would'st believe in my lesson, thou should'st have her no longer,

But in thy mind should'st avoid her: Thou shalt not have such love,

Shalt not sin so greatly." Sorrow did enter

The woman's heart at these words. She feared he would persuade

The world-king with his speech and his words of wisdom To leave, to forsake her. Many loathsome things she began

To plan and to plot; and she hight her squires, Her earls to take captive the innocent And put him in prison, place him in chains, 
Lock him in limb-fetters. She dared not deprive him of life

Because of the folk, since all were his friends: They knew him as good and as worthy of God, Held him for a soothsayer, as so well they could. There was come the time for the Jew-king's birthday, As the wise men of the folk had reckoned well, That he had been born and brought to this light. It was the custom that each earl should celebrate, Each man of the Jews mark it with feasting. There was a mighty crowd

Of men gathered together in the guest hall, Leaders and dukes in the house, since their lord Was indeed on the king's throne. Many Jews did come Into the great hall there. Glad-hearted were they, Blithe in their breasts. They beheld their ring-giver, Were really in rapture. Wine was brought to the room, Clear wine in the bowls, and the cup-bearers ran back and forth,

Going with golden cups; gladness was there, Loud in the halls. The lords were drinking;

The herdsman of Jews bethought him with joy, Pondered how best he might please the people. He hight go forth that gay, young girl, His brother's bairn, as he sat on his bench Haughty with wine; to the woman he spoke, Greeted her before the men-guests and most eagerly bade her,

That she begin some merriment here before the guests, Something fair in the feast-hall. "Let the folk see What thou hast learned to make joyous the many, Make them blithe on the benches; if thou doest my bidding, My word before this world-folk; then will I verily tell unto thee

Loudly before all these landsmen, and thus let it be done, 
That I will give unto thee all that thou asketh Before these my ring-friends, though thou demandest Half of my realm, half of my kingdom;

So shall I do, nor shall any world-men

Turn me with words; but truly it shall be accomplished."

Then the maid was thereafter inclined in her mind,

In her heart, to her lord, so that in the house, In the guest-hall she began much gaiety now, Even as the custom of the folk did command, The way of the people. The maid did play, Most merrily romped through the house. The minds of the many,

Their hearts were happy. When the maiden had served The folk-king there for his thanks then, And had served, too, his earlships all, as many as were Of good men present, she would fain claim her gift The maid in front of the multitude. To her mother she went

To speak and asked her forthwith - for she was anxious to know -

What she should bid him, bid the bastion's warden give unto her.

Of her own mind her mother did tell her, hight that before the men

She should ask for naught else except that he give her There in the hall John's holy head

Bereft of its body. For the folk it was baleful,

For the men in their minds, when they heard the maid speaking thus,

For the king it was, also; but he could not break it, his pledge,

Turn his word away. Therefore he bade the bearers of weapons

To go from the guest hall, take the good man And relieve him of life. Not long thereafter they brought The holy man's head up to the hall, gave it the girl, To the maid before the many. To her mother she took it. 
And that was the end-day of the wisest of all men, Who ever came to this world as a child born of woman, Of a wife from an earl - excepting ever that One, Whom the Maid did bear, she who had known no man Anywhere in this world; but the All-Wielder so destined it From the fields of Heaven by the Holy Ghost The Mighty God had so marked it. Never was man like unto him,

Neither before nor after. Now the earls turned to him, The men around John, his followers many, His beloved disciples. In the sand they buried His beloved body. But well did they know He could claim God's light, along with his Lord, Heavenly glory in that home on high $\mathrm{He}$, who was blessed indeed.

\section{XXXIV}

So his disciples fared thence, John's followers went, most woeful of spirit But holy of mind. The death of their master Filled them with sorrow. They repaired then to seek The Son of the Wielder away in the wilderness, Christ the Almighty, and made known unto Him The good man's demise: how the master of Jews Did heave off the head of the holiest of men With the sword's edge. The Son of the Lord had no wish To speak of His own pain; for He knew that this soul Was held in all holiness against the haters, In peace 'gainst the foe. Thus He grew famous Across the country, $\mathrm{He}$, the best of those teaching In the wilderness there; world-men did gather; To the folk He did come, for they had great longing For the wisom of words; and He had long wanted, The Son of the Lord, to lead such a gathering Of the land-folk to the light of the Lord, To turn the folk to His will. The Wielder did teach, 
The Mighty Lord taught all the long day so many of mankind,

Folk from all over and from foreign lands, until in the evening

The sun did sink to its seat. Then His disciples twelve

Did go to God's Bairn and told their Good Lord

In what dire need the men did there dwell; quoth that they did need His help,

The world-folk in the wilderness there; "Not well can they hold themselves upright,

The heroes, for the pangs of their hunger; now, Lord Good and Most High,

Let them go to find lodgings. Nearby lie towns

Filled with folk aplenty; there they will find meat to buy,

The world-folk there in those bailiwicks." Thereupon

Wielding Christ spoke again,

The Lord of the Land-folk, quoth that there was little need,

"That they forsake My fair teachings

Because of their poverty. Give these people enough.

Let them come here gladly!" His words had he ready,

The wise man named Philip; quoth that there were so many,

Such a multitude of mankind, "Though we might have meat

Ready to give them, were we able to buy it

And for that sold together two hundred pieces of silver,

Still would I doubt that each would have some.

So little were that for these land-folk." Then again the Land-Warder spoke

And asked them, anxious for knowledge, The Master of Men, how much of meat, Of food they had gathered. Then again with his words Andrew did speak before the earls to the All-Wielder Himself, And said now to Him that they had naught for the journey, 
"Naught but five breads of barley among the followers, and fishes twain:

How can that serve such a many?" Mighty Christ spake

$$
\text { again, }
$$

The Good Son of God, and hight they divide into groups,

The crowd, into sections; and hight they should sit,

All the lords, on the ground; the hordes of the land-folk should lie

On the green grass; and to His followers goodly he spoke, The Best of All Bairns; hight them go bring the bread And fetch forth the fish. The folk bided still The great crowd was sitting. Through His strength and His power

The Lord of Mankind at this moment did bless the meat, The Holy Heaven-King, and with His hands He did break it, And to His disciples He gave it, hight that they should take it and divide it

Among the multitude there. Their Master's word they accomplished.

To each man gladly they carried His gift, The holy help. It waxed in their hands, The meat for each man: for the multitude There came a life full of joy; the landsmen all, The folk had their fill — as many as had fared there together

From all the wide ways. Then Wielding Christ Hight His disciples go, and hight them watch well, That the leavings left there would not be lost, Commanded them gather the many of mankind When they had had their fill. There was left of the food,

Of the bread so much, that they gathered baskets Twelve of them filled. That was a great token, A great deed of God, since one counted together, Without wife or child, of world-folk there, Fully five thousand. The folk understood, The men in their minds, that it was a Lord Most Mighty 
Whom they did have. They did laud the Heaven-King, The people did praise Him; said that no wiser prophet Would ever fare in this light or that from God $\mathrm{He}$ would have greater might in this mid-world here, A more honest heart. All of them did say That He was worthy of holding all wealth, That indeed He should own all the realms of earth, The wide throne of world, "since He hath such wit, Such great power from God!" The people all thought it meet

That they raise Him to the highest of hights,

Choose Him their King: to Christ this was worthy of naught,

Since He Himself had worked this world-realm all through his power alone,

Had made earth and the high heaven, and had held them since, Both the land and the landsmen - but the loathsome foe Believed naught of that: that all stood 'neath His rule The power over kingdoms and over empires, too, The judgment of man. Still through the speech of these men

He cared not to have it, His rule - He, Holy Lord Have the name of World-King. Therefore He began no further word-strife

With these people there; but He went where He willed Up on a mountain; God's Mighty Bairn fled The insolent talk, and He told His disciples To sail over a sea; and He Himself said Where they should go to greet Him again.

\section{$\mathrm{XXXV}$}

The people parted and spread through all lands, A great folk scattered, for their Lord had gone Up on the mountain, the Mightiest of Bairns, Wielding as was His will. On the water's shore Gathered the disciples of Christ, whom He Himself had chosen, 
The twelve for their goodly faith; nor felt they doubt;

But in God's service they would gladly go

Over the sea. They let the high-horned ship

Cut through the strong stream, the clear wave and the water sheer;

The light of the day, the sun strode to rest. Night surrounded

The seafarers with mist; the earls strove on, Forward in the flood. Now the fourth hour

Of night was come. All-Saving Christ

Warded the wave-farers: the wind grew great,

The sea 'gainst the stem; with trouble they steered it,

The ship through the wind. The warriors grew fearful of mind,

Their hearts filled with care. The lake-farers indeed

Never believed that they would ever reach land

Because of the battle of weather. There they beheld

Christ,

The Wielder, walking over the waves on the sea,

Faring on foot. Into the flood he could

Not sink, not sink into the sea; for the power of Him

Himself

Held Him on high. Their hearts became fearful,

The minds of the men. They feared the mighty Fiend

Had done this to deceive Him. Then their Dear Lord did speak unto them,

The Holy Heaven-King; and said that $\mathrm{He}$ was their Lord, Splendid and Mighty. "Now in your minds

Shall ye all take courage; nor be ye frightened of spirit.

But behave ye boldly: for I am God's Bairn, The Son of Himself, and against the sea I shall help you,

Against these flood-streams." Then a man did answer From upon the ship, a sage most worthy, Peter the good: that no longer he wished to endure the pain, 
The woe of the water, "If Thou beest the Wielder, Master Most Good, as I think in my mind, Bid me come unto Thee across the flood of the sea, Dry over the deep water - if Thou art indeed my Lord, The Master of Many." Then Mighty Christ Hight him come unto Him. He was soon ready, Stepped on the stem; and striding, he went Forth to the Lord; the flood held him upright, The man through God's might, until in his mind he began To dread the deep water, when he saw it driven The wave - by the wind: The flood wound around him, The billows about him. But even as in his mind he did doubt,

So the water grew weak beneath him. And into the wave, Into the sea-stream he sank; and straightway he called To the Bairn of God and eagerly bade Him, That He save him there, since he, His thane, was In distress and in need. Then the Lord of the Nations Embraced him with His hands and His arms, and straightway did ask him,

Why he was doubtful. "Why, thou should'st trust well And know most verily that the might of the water, Of the sea itself could not hinder thy steps,

That of the lake-flood thy feet for as long as thou believest in $\mathrm{Me}$,

In thy heart hath a faith steadfast. Now I shall help thee, In thy need shall save thee." The Almighty so took him, The Holy Man by the hand: here again the clear water Became firm under foot, and they fared together Both step in step, until they came aboard ship, Stepped from the stream. And at the stem Sat the Best of All Bairns. Then the broad water, The stream became stilled; and they came to the shore, The landfarers indeed did come to the land Through the battle of waters; and said thanks to the Wielder,

Gave praise to their Dear Lord in deed and in word. 
They fell to His feet and did speak full many Words of wisdom; quoth that they right well knew That He Himself was verily the Son of the Lord Here in the world and wielded power

Over the middle earth; and all men He could help, Whosoever they were, as He had done on the flood 'Gainst the battle of waters.

\section{XXXVI}

Then All-Wielding Christ

Turned His steps from the sea: The Son of the Lord, God's only Child. Heathens did come to Him, Foreign folk fared to Him there. For from afar They had heard of His good works: that so many true words He did speak; for He longed greatly to further such folk,

So that straightway they would serve God gladly, Becoming true vassals of the King of Heaven, The many of mankind. So He made His way across Judea, Sought out the city of Sidon; His disciples He had with Him,

Christ's followers good. There a woman came toward Him From another tribe: of aethling birth was she, From the kith of Canaan-land; she bade the Lord Christ so strong,

The Holy One, to grant her His help: quoth that great trouble had come to her,

Sorrow for the sake of her daughter; said she was ensnared by sickness,

Deceived by treacherous devils. "Now is her death at hand.

The wrathful wights have robbed her of wit. Now I beg Thee, my All-Wielding Ruler,

Thou Son of David himself, from such sickness release her,

That Thou mayest mercifully protect this poor maid 
From the grievous devils." But All-Wielding Christ gave Her no answer. Therefore she went after Him, Followed Him boldly, till she came to His feet, And weeping did speak unto Him. The disciples of Christ Bade the Master that $\mathrm{He}$ be mild in His heart To the woman. Then had ready His word The Son of the Lord, and unto His disciples He spoke: "First shall I be of use to the folkships here, To the people of Israel, so that a pious spirit They shall have for their Lord. For they are in need of help:

The land-folk are lost; they have left and forsaken

The word of the Wielder; with doubts are they troubled these people -

Harboring treacherous hearts. Nor is the host of Israel Willing to hear their Lord; but they are unbelieving, The men in their Master. Then to the rest of mankind Help shall come later." Lo, most zealously then The woman begged with her words, that All-Wielding

Christ

Become mildly inclined, that she might henceforth enjoy Her child, having her hale. Then the Lord spoke to her, The Magnificent and Mighty. "No man," quoth $\mathrm{He}$, "hath the right,

No person ever, to do good or give alms in such manner, That his own bairns will be bereft of their bread, Deprived 'gainst their will, so that they suffer great pain,

Grim, hateful hunger; and feedeth his hound-dogs with their food."

"True it is, Wielder," quoth she, "what Thou speakest indeed with Thy words,

Most truly dost say. Why, oft 'neath the tables

In the halls of the lords, the puppies hop hither And yon for the crumbs, full many of which fall From the board of their master." The Peace-Bairn of God heard 
The will of the woman, and with words He did speak: "Well that thou, wife, hast goodness of will.

Great is thy faith in the power of God,

In the Lord of the Land-folk. Lo, all will be done

For the life of thy bairn, even as thou hast bidden of

$$
\text { Me!" }
$$

And straightway was she healed, as the Holy Lord had said

With words of truth; and the wife was happy

That henceforth she would be blessed with joy in her

bairn.

Christ the Healer had helped her indeed,

Had snatched her away from the strength of the Fiend, Guarded her against the loathsome wight. The Wielder went forth.

The Best of All Bairns sought Him another borough, Which was so thick with the throngs of the Jews, Settled with south-dwellers. There, I discovered, He greeted His followers whom in His goodness he had chosen,

Disciples who gladly stayed for His wise speech. "I shall ask of you all,

With My words," quoth He, "My followers: What say the Jews,

That notorious folk, who I am among men?” Happily His friends gave answer to Him, His disciples: "The Jewish folk," they said, "The earls are not of one mind. Some say Thou art Elias, The soothsayer wise, who was here long ago, A good earl among these folk; some say Thou art John, Our Dear Lord's herald, who once did dip The world-folk in water. But with words they all say, That Thou art some sort of noble, some aethling man, Some soothsayer or prophet, who hath taught the people Once before with his words. And once again Thou art come to this light

To teach the kith of mankind." Wielding Christ spake again: 
"What quoth ye that I be?" quoth $\mathrm{He}$, "My followers, My landsmen beloved?" Then not late with his words was he, Simon Peter; but straightway he spoke -

One for them all - of good spirit was he:

Daring in thought, he was dear to the Lord.

\section{XXXVII}

"Thou art truly the All-Wielder's Son, The Living God, who created the light, Christ, King Eternal: so willingly do we quoth, We Thy disciples, that Thou art God Himself, The Best of All Healers." Then his Lord spoke to him, "So blessed art thou, Simon," quoth He, "Son of Jonas, thou thyself couldst not have

Marked such thoughts in thy mind; nor could any man's tongue

Show thee with words. But the Wielder Himself did this for thee,

The Father of All Folk-Bairns, that thou spakest so forthright,

So deep of thy Liege. Dear shall be thy reward, Limpid and pure thy belief in thy Lord: like unto a stone is thy spirit.

So strong art thou like unto a rock; and the children of men shall call thee

Saint Peter; and on this stone men shall build My great hall,

God's holy house. There shall His family, His household All gather, blessed, together, and against thy strength, Thy power, the portals of hell cannot stand. To thee I present it,

The key to Heaven's kingdom, so that o'er the Christian folk

Thou shalt after Me have the most might; the spirits of men

Shall all come to thee; for thou shalt claim great power 
O'er the bairns of mankind. Whomsoever thou would'st bind

Here on this earth: for him both is done,

For him the kingdom of heaven is locked and for him hell lieth open,

The burning fire; and whomsoever thou would'st again unbind,

Whose hands unfetter: for him is Heaven's kingdom

Unlocked, the greatest of lights, and life everlasting,

God's fair, green meadows. With such gifts I would

Reward thee thy faith. Still I would not that ye proclaim now to the folk,

To the multitude yet, that I be the Mighty Christ, The Own Bairn of God. For the Jews shall still bind Me, In guiltiness tie $\mathrm{Me}$ and torture Me most terribly, Do Me great wrongs here in Jerusalem, With spear-point attacking, with the sharp edge against Me,

Relieve Me of life. Through the power of the Lord here in this light

I shall arise though from death on the third day."

Then in sorrow was he, Simon Peter, the best of all thanes;

Most grieved he of mind. And to the Master he spoke, The warrior in whispers. "That is not the will of the Wielder,

Of Mighty God," quoth he. "It cannot be that Thou should'st endure

Such pain 'mid this people. There is plainly no need, O Holy Master!" Then Christ Mighty and Marvelous, The Lord, did reply - he was dear to His heart "Why," quoth He, "thou art now opposed to My will, Thou best of My thanes? Thou knowest this folk, Hast ken of the customs of men. But God's might, which I must accomplish,

That wittest thou not. With words of truth I can tell thee much: that here 'mid the people stand 
Disciples of Mine who shall not die,

Not begin the trip hence, before they shall see Heaven's

$$
\text { light, }
$$

The kingdom of God." From His disciples He chose

Soon after that Simon Peter,

Jacob and John, those good men twain,

Both of the brothers. And He betook Himself then upon a mountain

With His disciples aside from the others - God's Bairn so blessed

With His thanes three; Lord of this Folk, Wielder of World, He would show unto them

Wonders a-many, such tokens, so that they should trust and believe

That He Himself was the Son of the Lord, The Holy Heaven-King. At a high wall

They climbed stone and cliff, till they came to a place,

These men, close to the clouds, which All-Wielding Christ,

The Strongest of Kings, had Himself chosen, That He would reveal most verily His godliness

To His disciples, His divinity A bright, shining picture.

XXXVIII

When He bent low in prayer, Lo, there upon the mountain His whole appearance, His garb became changed. His cheeks became light, Shone like the bright, shimmering sun: so shone God's Bairn.

Light was His body, and long rays shone Radiant around the All-Wielder's Bairn, His raiment so white

To the sight as is snow. Then a marvel was shown Up there on the mountain: Elias and Moses 
Did come there to Christ to exchange words with Him, The Strongest of Kings. There was winsome conversing, Good words among men; where the Son of God Would fain have talk with those famous men. So blithe it was, up there on the mountain. And the light shone bright,

And it was like unto that goodly garden, that meadow green, Like unto Paradise itself. And Peter there spoke, Hero hardy of spirit and to His Lord he did speak, Greeted the Son of God, "Good it is to be here, If Thou hast so chosen, O Christ All-Wielding, That men on these hights build Thee a house, Make it most splendid; and for Moses a second; And a third for Elias. This is the home of joy, The most winsome possession." Just as he spoke these words,

The air clove in twain: from the clouds light shone clear,

A glistening glow. And the good men

Were wrapped in a radiance. Then from the clouds rolled

God's holy voice. And to the heroes there

He Himself said that this was His Son,

The Most Beloved of the Living: "I like Him well, To My heart He is dear. Ye shall hear Him,

Following Him gladly." Then the followers of Christ, Those men, could not withstand the cloud's clear light, The word of God and its might, which is great. But they fell forward, and they feared indeed

They would lose their lives. Then the Land-Warden did go to them;

And with His hand He touched them, the Best of Healers, Hight they should feel no dread: "No harm shall come to you here

From these blessed sights which ye have now seen, These marvelous things." Then the men's spirits In their hearts were healed, and healed were their minds; In their breasts there was comfort: for they saw God's Bairn I08 
Standing alone. The other, though, Heaven's light, was again hidden. Then the Holy Christ Went Him down from the mountain, and $\mathrm{He}$ did then bid His followers that they tell not unto the Jewish folk

Of the sight they had seen. " "Until I Myself here In splendor shall stand up from My death, Arise from My rest. Then may ye relate it, Spread it over the mid-earth and its many peoples, Wide o'er this world.

\section{XXXIX}

Then Wielding Christ

Went again to Galilee-land. Great Christ sought His landsmen,

The home of His kin. With bright, clear pictures

He spoke much unto them. And the Son of God

Concealed not sorrowful tidings from His blessed disciples,

But openly He said all things to them,

His followers good, how the Jewish folk

Would torture Him all terribly. Then troubled were they,

The wise men, greatly, and grieved at heart,

Saddened of spirit, when they heard their Lord,

The Son of the Wielder, telling with words

What He would endure here midst the earth-folk, Willingly all among the people of world. Then All-Wielding Christ,

The Man, went from Galilee and sought a city of Jews.

They came to Capernaum. There He found a king's thane, Proud 'mid the people; quoth that he was the trusted courier

Of the noble emperor; he greeted thereafter

Simon Peter; and said he had been sent here

That he remind each man and every

Of his head-tax which he must pay as a tithe

Here to the court: "Nor can any man hesitate, 
But he payeth unto him his choicest treasure.

Only your Master alone hath omitted His tithe, Hath neglected it. Nor will my lord like this, When they inform him of this, the aethling emperor." Then Simon Peter went straightway. He so wanted To tell this unto His Master. But in His mind Holy Christ already knew; for from Him naught could be hidden,

Not even a word; but He well knew indeed

The mind of each man; but he admonished His thane, Simon Peter of fame, that into the sea

He should cast his hook. "Whatsoever thou dost catch, What fish at the first," quoth $\mathrm{He}$, "from the flood

$$
\text { thou must draw it, }
$$

Wedge open its jaws: from under its chin mayest thou take

Golden guilders, with which thou shalt give

The man enough of the tax which he seeketh from us, from Me and from thee."

He needed bid him thereafter no more, Give him no other words: but the Good Fisher did go, Simon Peter; into the sea he did cast His angle, his hook in the wave; and verily then He drew a fish from the flood. Its jaws

$\mathrm{He}$ tore open with his two hands. And from under its chin took

The golden guilders. And all he so did as God's Son Had told him with words. So was the strength of the Wielder,

His might made manifest, how each man and all Should most willingly pay to his world-lord here The taxes and tolls determined against him, And do so gladly; nor should any forget this, Neglect or deny in his mind; but mild in his heart, He should serve him humbly. So should he work The will of God and still gain the grace Of his worldy master. 
So Holy Christ did teach

His disciples good: "If against you," quoth $\mathrm{He}$, "any man

Do act in sin, then take ye this man aside,

This warrior, with whispers, and speak ye wise counsel

And teach him with words. Should he not be worthy

To hear your teachings, then fetch ye hither

Other men and good; and with his grim works reproach him,

Say them forth most soothly. If then his sins

His evil deeds do not grieve him, so make ye them open to others,

Most revealed to the multitude, and let many men

Know his wrongs. Then easily he will repent his works,

In his heart indeed rue them, when he heareth that so many folk,

Bairns of mankind have watched them and warded off with their words

The works of his evil. If even then he will not change, But scorneth such a many, then let this man fare forth, Believe him a heathen, and let him be loathsome unto you in your hearts.

In your minds avoid him, unless God the Mild, The High King of Heaven, grant help unto him, The Father of All Folk-Bairns." Peter then asked, The best of all thanes then questioned the Lord, "How often shall I absolve from sin this man Who hath done loathsome work against me, Beloved Lord? How many times shall I take from him all his blame For his wicked works, before rewarding the wrongs By wreaking vengeance?" Then spoke again the Warden of the Land.

The Son of God did give answer unto His goodly thane:

"I shall never say unto thee: seven, as thou thyself hast spoken,

Hast made known with thy mouth. I add more thereto:

Seven times seventy! So shalt thou absolve each one 
From evil, from sin. So I would give unto thee Teachings, a word most true. Since to thee I have lent the power,

That thou beest the highest one of my household To many of mankind; so shalt thou be mild unto them, Merciful unto the multitude." Then a young man Came to the Teacher, and Jesus Christ he did question: "Master Most Good," quoth he, "What must I do, So that I may reach the realms of Heaven?" All goodly riches had he gained indeed, Many a treasure, too, though mildness of heart He bore in his breast. Then spake God's Bairn unto him; "Why speakest thou of a Good One? There is no man But that One Single One, who shaped this All This world in its winsomeness. If 'tis thy will, Then shalt thou hold to the holy teachings, Those which the Old Law command thee follow: That thou shalt not slay; nor swear falsely, Neither commit adultery; nor bear thou false witness Nor steal nor cause strife; nor be thou too stubborn of mind,

Nor hating nor hateful; commit thou no robbery. Forsake thou all envy; to thine elders show kindness, To thy father and mother. Be thou fair to thy friends, To thy nearest be gracious. Then wilt thou be granted joy

In the kingdom of Heaven, if thou wilt keep this And follow God's teachings." Again the young man did speak:

"All things have I done," quoth he, "as thou now dost teach

And tellest with words; that I have no whit left undone Since the days of my childhood." Then Christ did begin To turn His eyes onto him. "One thing," He told him, "Is still lacking in thy works. If thou hast the will, That thou would'st serve thy Lord most perfectly still, Then shalt thou take thy hoard and thy treasure; 
Thou shalt rid thyself of thy riches all,

Order thy precious jewels to be portioned out

And shared with the poor. Then shalt thou have

A hoard in Heaven. Come thou then as healed unto $\mathrm{Me}$

And follow My path. Then shalt thou have peace ever after."

Then the words of the Christ caused great worry and care

To the child-young man. His mind was sore,

About his heart his spirit. For he had great wealth,

Had won great treasure; he again turned away.

In his breast he felt burdened indeed,

In his heart most heavy. Then Christ looked after him,

The All-Wielder, since He so willed,

And said to His disciples, who were there, that it was

even so hard

For a rich man to reach the realms of Heaven:

"More easily may an elephant, though it be unseemly great,

Go through a needle's eye, be that eye so narrow Slip through more softly, than this soul into Heaven, The soul of this wealthy man, who hath turned his will to world-things entirely,

The thoughts of his mind, and mindeth not the great might of God."

XLI

Him answered then an aethling most excellent and honored, Simon Peter; and speaking, he bade

His Blessed Lord: "What reward shall we look for, What goods to repay us - we, who have forsaken

Our lands and our heritage for love of Thy following,

Our farmyards and families, and chosen Thee for our Lord, Following Thy footsteps? What good will there be for us, What long-lasting reward?" The Lord of the Land-folk Himself said unto them: "When I shall come to sit," quoth $\mathrm{He}$ 
"In My might and My power on that most Renowned Day, When I shall deal out the dooms to the people of earth, Then may ye sit with your Master, may wield His affairs Ye may judge Israel's aethling folk

By its deeds: so honored will ye be up there.

For I verily say unto you: whosoever acteth on this earth, So that for My love he leaveth the dear home of his kin, He shall receive a tenfold reward, if he acteth

Loyally, with pureness of heart. Above shall he have

\section{Heaven's light.}

Eternal life will lie open." Therefore the Lord, The Best of all Bairns, began to speak pictures, Told how a man of great fortune in former days Lived 'mongst the land-folk: "He had laid aside wealth, Gathered great treasures unto him; and ever with gold He was decked and with silken stuff and with the sheen Of fine jewels; and so many goods he had stored away In his buildings; and at banquet He sat every day. There was splendid carousing And joy on his benches. There was a beggar-man also: Lame of limb was he and Lazarus hight; And every day he did lie in front of the door,

Where he knew the rich man received food in the guesthall

And sat at his banquet; and outside bided

The poor man; nor was he ever permitted within,

Nor could he bring it about by his begging that bread

Be brought out to him, such bread as had fallen from the dish

Down beneath their feet. Not a thing did he gain

From the high man who ruled over the house; but only the hounds of that man

Came and licked on his wounds, as he lay there

And endured his hunger. Not one whit of help

Came from the man of fortune. Then I found out that fate Admonished the poor man most mightily

Of his end-days: that he should renounce 
His life and the tumult of men. The Lord's angels Did receive his spirit and so led him from there, So that the poor man's soul did sit in the lap Of Abraham. Ever henceforth he could now dwell In all winsomeness. Then Weird came also, That fateful hour, to the man of fortune, So that he should forsake this light; the loathsome wights

Lowered his soul, sank it deep into swarthy hell, In the furnace below to the will of the Fiend, Grubbed him deep into the Grim One's home. There he could gaze on

The good man, see Abraham, where he dwelt above In a life of joy; and Lazarus sat

Blithe in his bosom; received bright reward

For his poverty and wretchedness all. And the rich man there

Lay hot in hell, and he did cry up from there:

"Father Abraham," quoth he, "It is fearfully needful for me,

That thou becomest mild to me in thy mind, Merciful unto me in this flame. Send Lazarus unto me, That he fetch cold water for me in this furnace. Hotly I burn alive in this hell and I am in need of thy help,

That he slake my tongue with his little finger.

My tongue hath its token now: woeful torture for my evil counsel,

For my sinful speech. Now is come to me such reward!" Abraham answered unto him -- he was the ancient father "Ponder in thy heart," quoth he, "what thou hast had Of wealth in the world. Why, thou hast wasted thy rapture all,

Thy goods in the gardens, and what was to be given Hence unto thee. Lazarus here

Endured wrong in the light; had plenteous grief And pain in the world. For this he shall now have wealth, 
Living in happiness. But thou shalt suffer hot flames, The burning fire. Nor may any betterment

Come hither to hell. So hath Holy God

Made it fast with hands and with arms; nor may any one fare,

Any thane through the darkness - it is here too thick under us."

Then the earl spake again to Abraham:

From that hot hell did he beg for help, That he do send Lazarus himself

Down to the tumult of men, "so that he may tell Unto those brethren mine how I here burn And suffer great pain. Among the people, The folk, there are five: I am in great fear

That they shall also become sinful and shall suffer such

In this great fire." Then again spoke unto him

Old Father Abraham, quoth that they ever had had The folk - the old law there in their land,

The commandments of Moses, and from many a prophet

Their words also. "If they are willing

To hold and to keep them, then need they never enter into hell,

To sear in that fire. If they so fulfill that

Which those do bid them who read in the books

To teach mankind. But if they are unwilling to accomplish that,

They will also not listen to Him, who riseth from here,

A Man from death. In their minds let them

Choose for themselves which seemeth sweeter

To win so long as they are still in this world,

So that in the hereafter they have evil or good!"

XLI

So did $\mathrm{He}$ teach the land-folk all with His words of light, 
The Best of All Bairns; and with bright pictures A-many, the Mighty Lord did speak to mankind: Quoth that a blessed man had begun to gather Men in the morning, promised them money $\mathrm{He}$, the first of his family - a very fine reward: Said that unto each and to all he would give A coin of pure silver. So came together

Many men in the winegarden - and he commanded their work -

Gathered early at morn. Then also others did come in the forenoon,

And some came at the midday - the men to the work;

Some came then at nones, that was a late time

Of the summer-long day. Some even later did come:

At the eleventh hour it wass. And the evening arrived And the sun went to rest. Then he himself bade His overseers all, this lord of earls, That they give unto each man his money and pay, To each workman his rightful reward; hight that they were to give first,

To those who had been last, the land-folk in coming, The workers to work; and with his words he commanded them To give unto those men their mite last of all:

To those who had come there first willingly to the work. They weened greatly

That they should receive a larger reward, More pay for their work; but to all the people Was equally given. Then were they angered, Were all in a fury, those who came first to that place. "In the morning we came here," quoth they, "and toiled much of the day

In hard work, in labor during the unmeasured heat, In the shining sun. Now thou givest unto us no more of silver

Than thou dost to the others, who were here only a while Doing their work." Then had ready his word

The head of the household; quoth that he had not promised them 
More pay for their work. "What," quoth he, "I wield here the power

To give to each man and all an equal reward, Equal pay for his work." Thus All-Wielding Christ Meant, however, a mightier thing, when $\mathrm{He}$ spoke to the men,

Gave the folk such a word about the wine-garden,

How the workers did come in an unlike way,

The men to their work. So shall the bairns of this world,

The children of mankind, do in that clear, marvelous light,

Men on God's meadow; some may begin to prepare themselves

Already in childhood. Such a spirit is chosen, His will is good, and he avoideth the ways of the world, Leaveth behind him his lusts. He will never let it, his body,

Entice him to evil; but eagerly he learneth

Wisdom and the law of God, and leaveth behind

The will of the devil, the dire foe: so doeth he ever in this world!

$\mathrm{He}$ is so in this light, until there cometh of life, Of all age the evening; and he fareth thence and up on his way.

There his work all will be rewarded, Repaid with good in the realm of God.

Thereby was meant those workmen who in the morning Early began with their work, who until evening

Did so continue their tasks. Some also came to the work At the midmorn, having squandered the morning And spoiled their day's duties. So do many dullards, Frivolous folk. For much folly have they done, Varied deeds in their youth. Yea, they have learned wrong,

Have learned scornful speech and such words of evil, Until their childhood passeth away. And after their young years God's grace doth admonish them 
Blithe in their breasts. They turn to the better, Both in words and in works, and lead well their lives To their very ends. And rewards come to them For all their good works in the kingdom of God. Some men, however, forsake their sin

Not until mid-life, their dire misdeeds, turning their minds

To blessed things; and they begin good works through the power of God

And repent their wrong talk and rue their bitter deeds Well in their hearts; there cometh to them help from God, So that they believe as long as life keepeth within them:

With that they fare forth and receive their reward, A goodly prize from Lord God; nor are there gifts any better.

Some begin still later, when they have become old already And their age grows to its end; then their evil works begin to be

Loathsome to them in this light; and the learning of God Admonishes them in their minds and their hearts become milder.

They do good deeds to the end of their days and reap their reward,

The high kingdom of Heaven, when they repair from here, Receive their rewards, as those men did reap theirs Who came to the work in the vineyards there At the none of the day, at the ninth hour indeed.

Yet some grow so ancient and still have not atoned for their sins,

But increase them with every evil, until their evening doth come unto them,

And their world and its winsomeness passeth away; then they begin to dread their reward;

Their sins make them sorrowful quite in their hearts. They ponder sadly that they themselves

Have done wrongs as long as they possessed their power, nor can they repent, 
Atone for their deeds by other good deeds done so well but every day

They beat their breasts with their hands and they weep bitter tears,

Crying out loud their lament, begging their Holy Lord, The Mighty God that He grow mild; nor doth He permit their minds to despair -

So merciful is $\mathrm{He}$, who wieldeth His might over all. The longing of no man on earth

Doth He want to reject; but the Wielder Himself doth grant unto him

The holy kingdom of Heaven. Help is come to him later.

All shall receive their reward, though they are not come All at one time, the kith of mankind. Still the Lord, mighty and wise,

Giveth pay to all people, whosoever receiveth His belief:

One kingdom of Heaven: He granteth to all the kith of this earth

A reward, to all men. Mighty Christ did mean that, The Best of All Bairns, when He spoke His parables Of how the workers came to the wine-gardens, The men, all differently. Yet each did receive

Full pay from his liege. Likewise shall the children of earth

Receive their reward from Righteous God Himself, Most lovely pay, though some come so late.

\section{XLIII}

Then He hight them, His disciples,

His followers twelve come closer: they were the truest of men

On this earth unto Him. And the Mighty One did explain Unto them one more time what troubles there were Standing before them. "No doubt can there be," quoth He. Quoth they should go to Jerusalem to the folk of the Jews. "There shall all things be accomplished amid the people 
And be brought to pass, even as in earlier times Wise men did speak with their words about Me. Among the strong folk there they shall sell Me, The men to the host. Then shall my hands be held bound, My arms and fingers be fettered; full much shall I suffer, Scorn shall I hear, and hurtful speech, Mockery much and many a threat.

They will torture Me wounded with the edge of their weapons,

Rob me of life. But through the might and the strength of the Lord,

I shall arise again on the third day from death to this light.

I have not come, however, to the people here, So that the children of men have labor for Me, That the landsmen should serve Me, nor shall I so ask them, Make such demands of the kith of mankind; but I shall be of use

Unto them, serving them meekly. And for all those men I shall give My soul. And I Myself

Will release them with My life - those who bide here so

$$
\text { long - }
$$

The many of mankind awaiting My help."

Then $\mathrm{He}$ fared foreward. For He had firmness of spirit

Blithe in His breast - the Bairn of the Lord.

He would seek in Jerusalem the folk of the Jews:

That was His will. Well did He know

The hate-raging hearts of the people and the hard strife

And their wicked desire. The hordes then went

Before Jericho's bastions, and the Bairn of the Lord

Was mighty among the multitude. There men sat by the way;

Blind were they both: they had need of betterment -

Both these blind men from the Bairn of God, Since for so long they had done without light.

They heard the crowd coming and, most curious, did ask That twain wholly blind - what man, high-born and mighty, Was the first there amid the clans of the folk, 
The noblest at their head. Then one hero replied unto them,

Quoth that Jesus Christ there from Galilee-land, The Best of all Healers, was the highest of all:

Foremost was He 'mid His folk. Full joyous were they of heart,

Both the blind men, when they knew that God's Bairn, The Christ, was there 'mid the folk. They called unto Him with their words:

Loudly they called Holy Christ, bade that $\mathrm{He}$ find them help,

"Master and Liege, David's Son, be Thou mild unto us with Thy deeds.

Save us from our distress! As Thou doest for so many

Of the kith of mankind; Thou art kind to the multitude!

Thou helpest and healest!" Then the host of the people

With their words began to forbid them from calling the Wielder,

Lord Christ, so loudly. But the two listened not,

But ever more and still more over the crowd of the men

Did they call most loudly. Christ Healer did stop, The Best of all Bairns, hight that they bring them to Him,

Lead them to Him through the land-folk; and spoke alike wisely

And mildly in front of the many. "Why seek ye help of Me here?" quoth $\mathrm{He}$.

They bade Him heal them, bade that He make that their eyen be opened,

That He lend unto them of this light, that they might see the bustling life

Of the folk, might see the shining rays of the sun, This winsome, fair world. And the Wielder did so. And with His hands $\mathrm{He}$ did touch them; and $\mathrm{He}$ granted His help,

That the eyen be opened of the blind men twain, That they might see earth and heaven through God's holy strength, 
The light and the land-folk. Then they lauded God, Praised our Lord that they could enjoy the light of this day.

And the two went with Him and followed His tracks.

A favor was theirs; and the Wielder's work was made widely known,

And many did marvel.

\section{L I V}

A mighty picture,

A token was shown there where the blind men sat

By the wayside and endured wicked pain,

Most bereft of the light: by that are meant the children

of men,

All of mankind; how Almighty God

In the very beginning through His own great power

Himself created that single couple,

Adam and Eve. He gave them the upward way,

The kingdom of Heaven, but the hated one was yet near,

The Fiend with his wiles, and works of wickedness,

With sin he deceived them, until they forsook it -

the light -

Beauty unending. They were banished both

To a worse place indeed, to this mid-world here,

Endured in the darkness dire human toil,

Won unhappy exile, lost their worldly goods.

They forgot God's kingdom, but gave the devils service,

The Fiend's own bairns. Therefore were they blinded of heart,

The children of men in this mid-world here,

Since they would not know Him, God Mighty and Strong, The Heavenly Lord, who with His hands did create them, Worked them so, as He willed. So was this world cast away,

Forced into darkness and into great despair

And the dale of death. They did sit along the way 
Of the Lord, lamenting of heart, begging God's help;

But aid could not be granted unto them before All-

\section{Wielding God}

Would send unto these the True Son of Himself:

The Mighty Lord sent Him to this mid-world here

To make free the light for the bairns of mankind,

Opening for them eternal life, so that they could know

The All-Wielding Lord, the God ever Mighty.

I may eke tell unto you, if ye are so willed

To hope and to hear, so that the Healer's, the Savior's strength

Ye may recognize well how His coming became

Great help to the many in this mid-world here;

What He, our Master, did mean - so many a thing

With His acts and His deeds, and why that well-known town

Is hight Jericho, the one which standeth there in Judea,

Made well with its walls. That is named for the moon,

For that bright constellation: it cannot escape its time,

But on every day it doeth one or the other:

It waneth or waxeth. So do in the world,

On this mid-earth here, the bairns of mankind.

They fare forth and follow, and from them the old die away,

And the young come again and are born. And the children of men

Wax great until Weird once more taketh them out of the world.

This the Bairn of God did mean, as He left the bastions,

The Good Christ from Jericho, that the children of men

Would not be healed from their blindness, not see the

bright beam

And beauty eternal, before He Himself had assumed

Man's body and flesh in this mid-world here.

Then the children of men, who before sat in sin

And in suffering, bereft of their sight,

Enduring the darkness - they did perceive and did know

That to this folk the Healer was come from the kingdom

of Heaven, 
Christ the Best of All Kings. They could soon recognize Him,

Had perceived His path. Then the people cried out so greatly,

The men to the Mighty God, that He became mildly inclined, The Wielder, unto them. But their wickedness kept them

Most dreadfully, the dire sins, which once they had done,

Prevented their believing; but they could not prevent

The will of the people. For unto All-Wielding God

They did call most loudly, until He did grant unto them wholeness,

So that they might see the life never ending, Eternal light open before them and journey on

To the bright dwelling above. So did the blind men mean

Who at Jericho-burg called to God's Bairn, Who did cry aloud that He grant them healing, Light in this life. But a great lot of the folk Who stood in His way, both before and behind Him, Kept Him away with their words. So do those weighted with $\sin$

Unto the kith of mankind in this mid-world here.

Hear ye now how the blind men acted after they had been healed,

So that they could see the light of the sun -

Hear what they then did: they went along with their

Master,

Followed in His footsteps, spoke full many a word,

Lauding the Lord's Herdsman: so do the bairns of the land-folk still

Widely here in this world, since All-Wielding Christ

Hath illuminated them with His lesson, granted them light everlasting,

Granted the kingdom of God to every good man, The high, heavenly light and His help to that end To whosoever worketh to follow along on His way. 
Then Christ the Savior, the Good One, soon came Near to Jerusalem. And now there approached Him A great multitude all of good mind toward Him. They received Him with joy, and before Him they strewed The way with their garments, their weeds; and with herbroots,

With bright colored blossoms and the branches of trees they did strew it,

The field, with fair palms; and it so then came to pass That the Son of God did wish to go

To that most hated town. Joyous, the multitude

Of the people surrounded Him and raised songs of praise, The folk, all willingly: they said thanks to the Wielder That He Himself was come, $\mathrm{He}$ - Son of David To visit the world-folk. Then Wielding Christ, The Good, saw Jerusalem. The Best of All Men Beheld the town's bastions and the buildings of Jews, The high-horned halls and God's house as well, The most winsome of temples. Then within Him welled His thoughts 'gainst His heart. And the Holy Bairn Could not help weeping, but troubled of heart With many words He did speak - for His spirit was sore.

"Woe unto thee, Jerusalem," He wailed, "that the word of thy Weird

Thou knowest not, nor what still shall come over thee, How thou shalt be surrounded by the strength of a host, How grim-minded men shall besiege thee mightily The foe with its folk. For thou shalt never find peace With these men, or protection. Many will bring thee The weapon's point and its edge, bring thee words of war,

Consume thy folk-clans with the flames of fire, Lay waste to thy bailiwicks; fell these high walls To the earth itself. Not a rock will stand upright, 
No stone on another. But all the townships surrounding Jerusalem will be desolation for the folk of the Jews, Since they cannot see that their time draweth nearer; But their souls are in doubt, and they ween not at all, That the strength of the Wielder is visited on them." Then the Lord of Mankind went with the multitude Into the bright borough. When the Bairn of God Went into Jerusalem with His host of men, Was there with His vassals, there waxed the greatest of all songs:

With such loud voices they sang holy words.

Lo, the crowds of the folk did laud the word of the Lord,

The Best of all Bairns. The burg was astir, The people were frightened and asked first of all Who was that who was come there with the crowd, With that multitude great. Then spoke a man in reply: Quoth that this was Jesus Christ from Galilee-land, Who was come as a Savior from the city of Nazareth, Wise Soothsayer and Prophet, as a Help to the people. Then the Jews, who had a grudge against Him already, Became hate-filled of heart and hurting of spirit, Because the people did give unto Him so much praise, Did love so their Master. The dull-minded folk did go forth, So that they might speak words with All-Wielding Christ. Bade that He hight His disciples be silent here, Bade Him not to permit them, the people, to praise Him So much with their words: "It doth worry this folk," quoth they,

"These burghers here." Then again spoke God's Bairn: "If ye keep the children of men," quoth He, Lord Christ, "From praising with words the All-Wielder's might, Then shall the stones still shout it forth To the kinship of men, and the strong, tall cliffs, Before it is left undone; but that He shall be lauded Wide and far in the world." Then He went into the temple. He entered God's house. There He found a horde of the Jews: 
There were countless men, so many together,

Who had chosen for themselves a selling-place in there, Haggling o'er multitudes of small matters: and moneychangers did sit

Within the temple. For transactions daily They held it ready. Then God's Bairn was enraged, Drove them out of the temple far; quoth that it was a far righter deed,

If the children of Israel should come there to pray:

"And here in this house let them pray for help, That the Master of Victories make them free from sin Rather than that thieves should bargain their things in the house,

And villainous men make their usurious deals, The worst of all wrongs. No whit of honor Know ye in God's house, ye folk of the Jews." So did the Lord All-Powerful empty and order The holy house; and of help this was

To the many of mankind, who had heard of His might, Of His strength from afar. And they came there faring Over the long, long way. So many a one weak of limb, So many of the halt were healed, and the crippled of hand,

And the blind were made whole. So did the Bairn of God Do unto the willing folk, since He wields might over all, Over the lives of men and their lands as well.

XLVI

Before the temple He stood, Strong Wielding Christ, The Land-Warder Beloved, and lo, He took heed Of the hearts of the people, and their will; He saw a huge host

Bringing great treasures to the well-known house, Giving unto it gold, goodly webs of silk, Precious stones and jewels. Wisely perceived $\mathrm{He}$, Our Lord Christ, all this. There did come also a widow, 
A poor, ill-weirded woman; and she went to the altar, And in that treasure-house she put down just two Small coins of bronze; she was simple of heart, A woman of good will. Then spake All-Wielding Christ, The Man, to His followers; quoth that a far greater gift Had she brought to the altar than any other son of mankind.

"If wealthy men," He did tell them, "bring a treasuretrove,

An honor here to the house, still they have left more at home

Of the wealth they have won. Not so did this widow, When she gave all she had upon this altar:

All the wealth she had won. Not a whit did she leave, No goods in her garden. Therefore is her gift more And worthier to the Wielder, since she gave with such will To the house of God. So shall she receive goodly reward, Most long-lasting return, since she possessed such belief."

So I discovered that All-Wielding Christ

Taught them with words each day in the temple, The Master of Mankind. And many stood 'round Him, A great folk of the Jews, and hearkened to the good word,

The sweet word He spoke. Some were so blessed,

Some men from the multitude, that in their minds and their hearts

They began to learn and accept the lesson which the Warder of Lands,

The Child of the Lord, did speak in His pictures.

To some again the lesson of Christ was all loathsome,

The All-Wielder's word. Of hate-willed heart

Were all those who were the greatest among those governing, The princes of the people. These evil men did plan Trickery and snares with their words; they had taken adversaries

To help them, these men of the highest one; were thanes of Herod - 
He who was present with an evil intent to overhear all they said -

If the people did capture Him, that they might throw

Him in chains,

Might lay leg-fetters around His limbs -

Around Him, the Christ without sin. The crowd did come toward Him,

Bitter-minded, to speak unto God's Bairn,

The evil adversaries, to address Him with words.

"What, Thou art a sayer of law," quoth they, "unto all people?

Thou revealest so wonderous much truth. Nor is it of worth unto Thee

To conceal aught from a man because of his might;

But ever Thou speakest only that which is right, And with Thy teaching Thou leadest the crowds of the land-folk

Upon God's way. Among the people not a whit of reproach

Can one find in Thee. Now we shall ask Thee:

That rich and great ruler - what right doeth he have?

Caesar from Rome, who seeketh his tithe

From the clansmen here and hath counted out

What monies each man of us shall pay every year,

How much of the head-tax. Say, what in Thy heart hast Thou thought?

Is this right or no? Counsel Thy countrymen well, For we have need of Thy teachings." They wanted His answer,

But well did He know their will. "Why, ye liars all Against truth," quoth $\mathrm{He}$, "do ye tempt Me so boldly?" But it shall be of no help, no advantage to you.

That ye deceivers seek to capture me secretely."

He commanded that they carry forth the coins for the showing,

"Which are your duty to give." The Jews did bring out A coin of silver; and many did see

How indeed it was minted; in the middle appeared 
The pictured head of their lord. Then Holy Christ did question them

As to whose likeness lay in this picture.

They replied that it was the world emperor there

From the city of Rome, "who rules o'er this realm,

Wielding power here in this world." "That will I verily," quoth $\mathrm{He}$,

"Say unto you, that ye give unto him his own,

To the world-lord his wealth, and to All-Wielding God

Bring that which is His. That should be your souls,

The spirits of men." Then the minds of the Jews were made

Small in the gathering. The scoundrels assembled

Could not win out with their words, as was indeed their will,

To ensnare Him, since the Peace-Bairn of God

Warded off their wickedness, and He verily

Said unto them a soothy thing; still they were not so

blessed,

That they could receive it and it could then be of bene-

fit unto them.

\section{XLVII}

But they would not leave off, but instead ordered a woman led forth

In front of the crowd; she had committed sin,

Had truly done wrong; the woman had been taken

In adultery and had forfeited her life,

So that the bairns of mankind could deprive her of

$$
\text { breath - }
$$

Lay claim to her age: for so was the law.

They began to question Him; the bold people there -

Wicked they with their words: what they should do with this wife:

Whether to kill her by torment or leave her quick and alive --

Or what judgment He would deal for such a deed as this.

"Thou wist," quoth they, "that Moses commanded these many 
With words of truth that any woman whosoever Is found in adultery must forfeit her life, And that with their hands the landsmen will unlife her By throwing sharp stones. Now Thou mayest see her here standing,

Ensnared in her sin: say what Thou willst!"

His foes had the wish to ensnare Him with words.

If He were to say that they should indeed let her live, Should permit her to leave here in peace, then would the people of Jews

Say that He had opposed their ancient law, The people's own land-right. If He hight them rob her of life,

The maid before the many; then would they say that no mildness of heart

He bore in His breast, such as God's Bairn should indeed possess.

So for whichever word Holy Christ would speak To the people, the many, they would then punish Him, Would deal out His doom. This our Lord Christ did perceive. Right well did He know the turn of mind of these men, Their wicked wills, when He spoke then to the folk, To all the earls gathered around. "Which of you," quoth $\mathrm{He}$ "Standeth here without evil sin? Let him himself go to her

And with his hands be the first of the earls here To pelt her with stones." Then the Jews stood about, Had their thoughts and were silent. Not a single thane Could find opposition unto this speech. And each man was reminded of his own evil-mindedness, Of his own dark sins; not a one was sure enough That after this word he would venture to throw A stone against the woman; but they left her standing alone inside.

The grim-minded people of the Jews did go thence, One after another, until there was not a single one Of the folk of the foe standing before them 
Who would have wanted to rob this woman of her years and her life.

Then I discovered that the Peace Bairn of God, the Best of all Men,

Did question her. "Whence came this Jewish folk?" quoth $\mathrm{He}$,

"Thy opponents here, who have accused thee to $\mathrm{Me}-$ ?

Those who today have wanted to torment thee most terribly,

To bereave thee of life - have they done one whit of harm unto thee?"

Then the woman gave answer again unto Him,

Quoth that through the holy help of the Savior no one had harmed her

To reward her sins. Then spake again All-Wielding Christ, The Master of Mankind. "Nor shall I do harm unto thee," He made reply,

"But go thou hence, hale and unhurt, and let it be

The care of thy heart, that henceforth thou sinnest no more."

The Holy Bairn of the Lord had helped her indeed, Had protected her life. Then the people of Jews stood there,

As bent on evil, as they had been in the beginning, Of wicked intent and wanting to continue their word-strife, Pondering, how to pursue it with the Peace-Bairn of God.

They had put doubts in the faith of the people:

The little folk standing about would far liefer Have accomplished His will, the word of God's Bairn, Have done even so, as their Lord did bid them.

They strove toward right better than those men with riches,

Held Him as their Lord; yea, as the Heaven-King even, And followed Him gladly. Then God's Son did go Within the temple. The people surrounded Him truly, The multitude of the men. He stood in their midst, Taught them, the land-folk, with words of light And in a voice loud and bright: there was great listening, 
And many a thane stood silent; and He bade them thusly: "Whosoever of the people be oppressed with thirst Let him come unto Me," quoth He, "and drink every day From that sweet spring. So may I say unto you, Whosoever of the bairns of mankind hath believed in $\mathrm{Me}$ Fast and firmly among the folk - that from him shall flow The living flood, flow from his body

The gushing water, the great well-springs

That are springs of life coming thence. This word shall come true,

Shall be done unto all folk, whosoever hath believed rightly in Me."

With this water All-Wielding Christ, The High King of Heaven did mean the Holy Ghost, How the children of men should receive Him, Light and reason and the life everlasting, The high kingdom of Heaven and Holy God's grace.

\section{VIII}

Then the people began to quarrel about the teachings of Christ

And about His words; haughty men stood about, Proud minded Jews - and they spoke much mockery, Heaped scorn upon Him, saying that they could hear full well

That angry and wicked thought did speak out of Him. "Now He doth teach evil," quoth they, "with every word." And again others did speak: "Ye should not reproach Him who teacheth," quoth they, "for words of life come Mighty out of His mouth, and He worketh many a thing, Many a wonder here in this world: that is no wicked deed, Clearly not the might of the Fiend, else could not such good be accomplished by Him,

But surely it cometh from All-Wielding God, From His strength all rightly. That may ye well recognize In His words of truth, that He wieldeth power 
Over all the earth." Then His opposers longed

To take Him captive straightway or to cast stones on Him, Had they not feared there the multitude of the folk, Been afraid of the people. Then spoke the Peace Bairn of God.

"Much good have I shown unto you," quoth He, "from God Himself,

Both in words and in works. Now would ye give me wicked reward

With your strong, hard hearts and pelt me with stones And bereave me of life." Then again the people replied, His dire opponents: "We do this not because of Thy deeds," quoth they,

"That we should want to deprive Thee of life.

But we do so because of Thy words, since Thou speakest such wickedness,

Since Thou dost praise Thyself and sayest such blasphemy, Proclaiming before these Jews that Thou art God Himself, The Mighty Master and Lord; and Thou art merely a man like us,

Art come from these clans." Then All-Wielding Christ No longer wished to list to the scorn of the Jews, The will of these wicked ones. But from the temple He went Over Jordan's stream. His disciples He had with Him, Those blessed thanes, who forever there tarried

To accomplish His will. Another folk He did seek;

The Lord Himself did work there, as was ever His wont, Teaching the land-folk: those who so wanted belief In His Holy word. Each man should well do so ever If he accepteth and receiveth it into his heart. Then I did hear there were come to Holy Christ Heralds from Bethany, and they said unto God's Bairn That women had sent them there on this errand Mary and Martha, maidens most comely, Such winsome women. Both He knew well. They were sisters twain, whom in His spirit He Himself did love for their mildness of heart, 
These women for their goodly will. Most verily they sent From Bethany for Him; for their brother was bedfast Lazarus he - and they feared for his life.

They bade that He come, All-Wielding Christ,

The Holy, to help them. As soon as He heard them

Speak about the sick man, He gave answer straightway,

Said that Lazarus' sickness, though so serious it was,

Would not do him to death. "But," He did say, "the love of the Lord

Shall here be accomplished. Nor shall any harm come unto him

The Son of the Lord did Himself stay there

Two nights and two days. The time then drew near,

That He teach these people the power He had,

Teach the Jewish folk there in Jerusalem.

Then the Son of the Lord did say to His thanes

That He would again seek out the Jews across the Jordan.

But His disciples did speak to Him in reply:

"For what reason, good Master, goest Thou so gladly,"

Quoth they, "over there? Was it not recently there,

That they thought to kill Thee because of Thy words?

Did want to pelt Thee with strong, sharp stones? Now

Thou strivest to go again,

Among that fight-seeking folk. Thou hast foes enough,

Overhaughty earls." Then one of the twelve,

Thomas, did speak - he was truly an excellent man,

A loyal thane of his Lord. "Let us never reproach His deeds,"

Quoth he, "nor reproach His will. But rather we should remain with Him,

Should suffer with our Lord. For that is the choice of a thane:

That he standeth steadfast with his Liege together,

Doth die with Him at his doom. Let us all do so therefore;

Let us follow His path, nor let our lives

Be worth aught against His, unless we may die

In this host with our Lord. So honor will live after us, 
A good word before the kinships of men." So the disciples of Christ,

The aethling-born earls, became all of one mind, Holding the will of their Lord. Then Holy Christ Himself Did say to His disciples, that a sleep unto death

Lay on Lazarus on his couch. "He hath given up the light,

Doth slumber on, on his bedstead. Now we shall fare on the way

To awaken him there, so that he may again see this world Alive, see the light: Then your belief will henceforth Be strengthened still more. So went He hence o'er the flood;

The Good Son of God did go with His vassals There to Bethany - the Bairn of the Lord Himself with His disciples - there where the sisters twain,

Mary and Martha, their minds filled with care,

Were sitting most sadly. Here was gathered together Much folk of the Jews from Jerusalem, Who wanted to comfort the women with words, So that they would lament less the death of Lazarus, The loss of the child-young man. Then as the Warder of Lands

Did go through the garden, it spread around that God's Bairn

Had now arrived, and that $\mathrm{He}$, so mighty,

Did tarry outside the castle. Then the twain, the women, Were most joyous indeed, when they heard that the Wielder, The Peace-Bairn of God, was now come unto them.

\section{XLIX}

'Twas the most wonderous joy for the woman to hear Of the Lord's coming and of the word of Christ. Her mind filled with care, Mary did go to the One so Mighty, 
Lamenting, exchanged words and spoke with the Wielder, Her heart muchly troubled. "Had you, my Master,"

Quoth she, "been nearer, O Best of Saviors,

Healer so good, I would never have needed to suffer

such hurt,

Such bitter care in my breast, and my brother would not now be dead,

Lazarus, far from the light; but he would still be alive,

Filled with this life. But I, my Lord, do believe

Most steadfastly in Thee, Thou Best of all Teachers.

If Thou would'st so bid the Bright Lord for aught,

He would grant it straightway; Almighty God

Would fulfill Thy will.” Then spoke again All-Wielding

Christ,

Answering the woman. "Let not thy heart within thee"

Quoth He, "become darkened, but I may make known unto thee

In words of truth, that thou shalt have neither worry nor doubt,

But that thy brother shall at the bidding of God,

Through the might of the Lord arise from the dead

In his own body itself." "So have I believed," quoth she,

That it will thus come to pass when the world doth end,

That he shall arise then again from the earth

On the day of his doom: then the dead will become quick

Through the might of the Lord; and so many of mankind

Will arise from their rest." Then Christ the Ruler did

$$
\text { speak, }
$$

The Almighty did utter open words to the women;

That He Himself was the Son of the Lord,

For the bairns of mankind both a light and a life

For the resurrection. "Never shall he die,

Take leave of this life, who believeth in Me.

Though the bairns of men do bury him deeply

And cover him over with earth, he is not yet dead:

The flesh is consigned to the soil, but the spirit is saved,

And the soul is still sound." Then the good wife again did speak 
To Him with Her words: "I verily believe," quoth she, "That Thou art the Christ, the Son of God. Well may one see this,

May know from Thy words that Thou wieldest power Through this holy creation over heaven and earth." Then I discovered that the other woman did come, Mary, with care-filled mind: and behind her came many Of the folk of the Jews gathered together. And to the Bairn of God

She, saddened of spirit, did say, why she was sorrowed With such grief in her heart; she lamented with groans The losing of Lazarus, of the beloved man, Giving forth mournful moans, until the Almighty's Bairn Was indeed moved in His heart; and hot tears streamed, Welling up as He wept. And to the woman He spoke, Hight that they should lead Him, there where Lazarus was lying

Consigned to the soil. A stone lay above him;

A hard boulder did cover him. The Holy Christ hight Them remove the rock so that right well $\mathrm{He}$ might see the corpse,

Might gaze on the body. Then despite the folk gathered 'round,

Mary could not help making known the care of her mind, and to the Mighty One

She did speak, "My Lord so Good," quoth she, "if one taketh away the stone,

Removeth this rock, then I ween, it will reek from there.

An unsweet stench will come forth, if I may so say

Unto Thee with words of truth - that there is no doubt of

$$
\text { that - }
$$

Four days and four nights hath it been, since he was consigned To his grave there." He gave reply unto her,

The All-Wielder unto the woman. "Why, I have verily told thee before, "quoth $\mathrm{He}$,

"If thou hast will to believe, then will it not be long Before thou shalt see, shalt know the strength of the Lord, 
The great might of God. Then many did go

And hove up the hard stone. Then Holy Christ did gaze Upward with His eyes and said thanks unto Him

Who had shaped this world. "Since Thou hearest My word," quoth $\mathrm{He}$,

"Thyself Lord of Victory, I will know that Thou doest so ever.

But I do so only for the great folk of the Jews,

That they may verily know that Thou hast sent Me into this world

To teach them, this land-folk." Then He called unto

\section{Lazarus}

With a loud, strong voice and hight him stand up And go forth from the grave. And his ghost did return And enter his body. And he began moving his limbs: He stirred 'neath his weeds; but he was still wound in them, Held tight by his shroud. Then All-Wielding Christ did hight

That they give him help. Then the men did go

And unwound his weeds. Winsome, he rose,

Lazarus to this light. His life had been granted him,

So that he might spend the fated span of his days

Henceforth in peace. The twain rejoiced full well,

Mary and Martha; nor may anyone

Truly say otherwise than that the sisters twain

Were indeed happy of heart. Many did wonder, Those of the Jewish folk, when they did see him

Rise sound from his grave - him, whom sickness had taken before

And whom they had dug deep down into the earth, Him, cut loose from his life. Henceforth he could live Hale and sound in his home. So may the Heaven-King's, May God's great power protect the life

Of so many a man, and may help him 'gainst the hate Of the Fiend - Holy God, to whomsoever He giveth His grace. 
Then the minds of so many of mankind and their thoughts as well

Were won for the Christ, when they themselves did see His holy works, since in this world such wonders Had never before come to pass. There were also some people,

Such strong-minded men - the might of God they had no will To acknowledge openly, but against His great power They fought with their words: for the Wielder's message, His lesson, was so loathsome to them, that they sought other landsmen

In Jerusalem -- there where the Jews Had their home and inheritance, their foremost town There they gathered a great crowd of grim-minded folk, And of Christ's work they did tell them; quoth that they had seen him quick

And alive - with their own eyes had seen the earl who had been in the earth,

Consigned to a grave four nights and four days, Had been dead and buried, until He with His deeds, With His words had awakened Him to see this world once again.

This was so hateful to these haughty men,

To the clansmen of Jews, that they commanded their minions, Their people to gather together and to turn the crowd Against Him - the great host; and against Mighty Christ They took counsel in whispers; "That is not good advice," quoth they,

"That we should endure it. Too many indeed of the folk Believe in His lessons. Then the landsmen will come And attack us with horsemen, and our overseers Will be warriors from Rome. Then bereft of our realm, Must we live and suffer the loss of our lives, We heroes, the loss of our heads. Then spoke a hoary man Over the crowd of the men: among the clans 
Within the borough was he bishop of the people. Kaiphas was he called, and by the kinsmen of Jews He had been chosen this year to take charge of God's house,

Be the warder, then, of the temple. "Methinks 'tis a wonder," said he,

"O praiseworthy people - ye are informed of a plenty:

Why is it that ye yet do not know, $\mathrm{O}$ ye folk of the

$$
\text { Jews, }
$$

That 'tis better counsel for the bairns of mankind That one relieve one man of his life And that he dieth most bloodily through your deeds, Forsaketh this life for the folk-clans here, Than that all the landsmen should forever be lost." But it was not bis will that he verily did speak Forth to the land-folk for the weal of mankind, Proclaimed to the people; but from God's power it came Through his holy office, since he had to care for God's house

In Jerusalem there - he, the temple's warder.

Therefore the people's bishop did speak, how the Bairn of God

Was to save all the children of earth with His single spirit,

With His own very life: and for all the land-folk That was a great gain, for He gathered the heathen, All-Wielding Christ fetched the men, as He willed. Then those most haughty men became of one mind, The clansmen of Jews, and in their crowd they did speak This far-known people, that they permit no doubt in their minds!

But whosoever might find Him here among the folk He should straightway make Him his captive, should bring Him

Forth to the diet of clans; quoth that they no longer cared

To suffer that one man should thus seduce them, 
The world-folk all. But All-Wielding Christ knew full well Even the thoughts in the minds of these men there, Their hate-angry hearts; for nothing is ever hidden To Him in this mid-world here; thereafter He had no wish To appear in the open among the many, among the earls Of the folk, among the Jews. For the Son of God Was biding that bright, glorious time which would be unto Him,

When He would endure great pain for these peoples, Torment indeed for the folk of the earth. For the time of

His doom

He knew full well. Thereupon our Lord went forth. All-Wielding Christ did abide in Ephraim. The Holy Lord did dwell in the high-walled city

With His vassals there; until it was His will

To return to Bethany once more with His mighty host, With His disciples good. The Jews did discuss His every word: "This bodeth no good," quoth they, "For the council of our realm. Though we do speak rightly, Still our cause cannot thrive one whit, since He can turn them,

The folk to His will; and all the world followeth Him, The landsmen for His lesson, so that we may do no whit Of harm unto Him, here in front of the folk."

Thus the Bairn of God did go into Bethany Six nights before it should hap - that gathering there In Jerusalem of the Jewish folk.

For the hallowed day they should keep for the holy tide, The Passover of Jews. God's Son did tarry Mighty among the many. A great crowd of men, Of folk did wait for His words. There two women approached Him,

Mary and Martha; with mildness of spirit

They served Him most humbly. The Master of Peoples 
Gave them long-lasting reward. He released them from all that is loathsome,

Absolved them from sin; and He Himself did bid That they should fare forth in peace against the Foe,

The women with His good permission; To His will had they turned

Ever their service. Then All-Wielding Christ

Fared forth with His people, the Lord of the Folk,

To Jerusalem, where dwelt the Jews,

All those hate-filled leaders, who there spent the holy time

Warding the temple. There were there many world-folk

Of most mighty clans; and they cared not to hear

The word of the Christ, nor had they a whit

Of love in their breasts for the Bairn of God;

But rather they were a proud, a wrath-filled people, An angry minded clan of mankind; and they had murderous thoughts

And evil within them: all wrongly they understood

The teachings of Christ, wanted to kill Him, the All-

Strong,

Because of His words. But there were so many of the worldfolk,

So many of the earlships about Him all the day long. The small folk did surround Him for the sake of His sweet word,

With so many people all the day, so that His enemies Among the folk-clans feared to make Him their captive, Avoiding Him there amid the many. Now Mighty Christ

Did stand inside of the temple and said many a word All the day long, until the light,

Till the sun went to rest. Then many did wend their way

Homeward, that kith of mankind. There was there a famous mountain

Outside near the city - so broad it was and so high, Green and so fair: it was hight by the Jewish folk The Mountain of Olives. Upon that did He go, 
The Savior Christ, where the night did surround Him. He was there with His disciples, though not one of the Jews

Did actually know this, since already He had entered the temple -

The Lord of the Land-folk - when the light came up from the east,

Received the clanships and said much unto them

In words of truth, so that not one in this world,

On this mid-earth here - not a single man is so wise,

Not one of the bairns of mankind, that he could repeat to the end

All the teachings He told in the temple there,

Did speak in the holy house; and with His words He hight them

To make themselves ready for the realm of God,

All men everywhere whosoever they be, so that on that best-known day

They may receive the love of their Lord.

He told them the sins they had committed and straightway commanded

That they atone for their deeds. Told them that in their hearts

They should love God's light and leave behind them all wrongs,

Evil haughtiness, and assume humility,

And take it into their hearts. Quoth that the kingdom of Heaven,

The richest of goods was really for them. Then right many of the men

Were turned to His will, when they heard God's word, Heard the Holy Message of the King of Heaven, Acknowledged great power and the Master's coming And the help of the Lord; yea, that the heavenly kingdom, That salvation was grown nearer, and the grace of God For the bairns of mankind. But some were so angered Some of the Jewish folk had such grimness of mind, 
Such hate-filled hearts... ${ }^{1}$

They wanted not to believe His word, but waged great battle

Against Christ's might: because of their wretched contention The folk could not find it - belief in Him, clear and firm. The grace was not granted them to be given the kingdom of Heaven.

Then God's Son did go, and His disciples all gladly with Him;

The Wielder went from the temple, as He so willed it. And again the Bairn of God did go up on the mountain, And He sat with His disciples and said much unto them In words of truth. They began to talk with Him about the temple,

The men about God's house, quoth that no goodlier Building had ever been builded by the hands of earls, By the efforts of man, never such temple erected With such great power. Then the Rich Prince did speak, The High King of Heaven - and the others did hear Him "I can yet tell unto you," quoth $\mathrm{He}$, "that the time shall soon come

That no stone shall be left standing upon any other, But it shall fall to the earth and fire shall devour it, The greedy flames, though it be so goodly,

So wisely worked. And that is the Weird of the world:

The green meads shall all pass away." Then His followers did go to Him,

And they asked Him softly: "How long shall it stand here?" quoth they,

"The world in its winsomeness, before the great turning will come,

Until the last day of light shineth through

Its covering of clouds; or when can we hope for Thy coming To this mid-world again to judge mankind and its dead and its quick,

1 Lacuna in MS. 
O my Lord most Good? We have longing to know,

O All-Wielding Christ, when that time shall come."

\section{I I}

Then All-Wielding Christ did give answer, The Goodly Man, Himself, to the many. "That hath the Good Lord so hidden," quoth $\mathrm{He}$ "The Father of Heaven's kingdom hath so concealed it, The Wielder over the World, so that not a one Of the children of men can tell when this noted time Shall come to the world; nor in truth can they know Either, God's angels, who are ever beside Him And stand in His sight, nor can they say it, With their words tell all truly, when it shall hap, That from the mid-world here the Mighty Lord Shall choose to call the children of men. He alone knows,

The Father, Holy in Heaven. From all others 'tis hidden:

From the quick and the dead, when that coming shall be.

Yet may I tell unto you what wonderous token Shall happen here before He shall come to this world On that famous day. For it shall be revealed in the moon

And in the sun as well; both shall turn swarthy, Be surrounded in darkness, and the stars shall fall, The white, heavenly beacons; this broad earth shall tremble,

This wide world shake. And many such signs shall there be:

The great sea shall rage grimly and the ocean tide grow To bring dread with its waves to the dwellers of earth. Mankind will shrivel and die in its mighty distress. People will pass away in their fears; and in no place will there be peace.

But wars so many will rise over the earth, Filled with hatred all; and one clan shall lead a host 
Against another. The battle of kings will arise, Mighty wanderings of hosts: and many a murder will there be -

There open war-death - that is a terrible thing That man should ever commit such murders.

Great ruination will spread awide over all the world The most farflung dying of men that was ever upon this mid-earth here

Through plagues and through pestilence. People lie sick; They do drop and they die; and their day endeth. With their life they fulfill it; a famine immeasurable, A grim, hot hunger fares huge o'er the bairns of all men, The greatest of starving; and that is not the slightest Of the torments which shall hap here in this world Before the day of all doom. Whenever ye see such deeds Being done in this world, then may ye verily know That the last day draweth nigh for the land-folk all, That most noted day, and the might of God And the stirring of heavenly strength and the Savior's coming,

The Lord's, in His glory. Lo, for these deeds

Ye may know a token in the very trees:

When they make buds and bloom and show forth leaf-blades, When they unfold their foliage, the children of men may know full well

That soon after this the summer draweth near, The warm and the winsome, and the weather is fair:

So know ye also by this token which I have told unto you, When the last day of life draweth near for the landfolk.

Now will I say unto you most verily that this folk, This people shall not pass away before this be fulfilled And My word becometh truth. Yet cometh the turning Of heaven and earth, and My Holy Word standeth In firmness henceforth, and all will be so fulfilled, Come to pass in this light, as I have said to these people. 
Verily, wake ye all: for the well-known day, The day of your doom cometh most certainly, and so doeth the strength,

The might immense of your Lord, and that most known of times,

The turn of this world. Against this be ye watchful, That He find you not suddenly asleep and stretched out On a couch of ease with all of your evil deeds, And filled with your sins. For the reckoning day Doth come in the deep, dark night, as doeth a thief Furtively all with his deeds: so fareth that day to mankind,

The last of this light, so that the land-folk know it not before,

Even as was the flood once in former days, Which destroyed mankind with its streams of water In the time of Noah; but now God saved him only, Him with his family, the Holy Lord,

From the flood's fierce onslaught; so did come also the fire

Hot down from heaven which surrounded the cities Around Sodom-land, as swarthy flames, Greedy indeed and grim, so that no man did go forth Still alive except Lot alone; him the Lord's angels Did lead from there with his daughters twain High onto a mountain; all others, both land and landsmen, The burning fire, the flames destroyed.

So suddenly did come the fire, and so also was the flood before:

So, too, shall be the end-day of earth. All men whosoever Should think ahead toward this thing. That is a great need For every man; there let each keep this care firm in his heart."

\section{I II}

"When ever it shall come to pass, that All-Wielding Christ, 
Man's Glorious Son, shall come with God's might, Shall come with the strength of the Richest of Kings, Sit on high in His own great might; and together with Him,

All the angels, too, which are above holy in Heaven;

Then shall the children of men and with them the heathen

Come all together; all the living kith of the land-folk

$$
\text { come, }
$$

Whosoever was born, hath lived here indeed in this light

Of the children of men. To all of mankind,

To the folk here all, shall the Lord Most Famous

Deal judgments, as were their deeds. The doomed men $\mathrm{He}$

The sinful, the lost men, to his left hand;

So He shall place the holy and blessed on His right side

$$
\text { also, }
$$

Greeting the good then and speaking most gladly to them:

"Come ye," quoth He, "Ye who are chosen, and receive ye the good kingdom,

The mighty, which standeth ready, made for the children of men

From the world's beginning. The Father of Mankind's Bairns

Himself hath hallowed it; ye may enjoy its blessings,

Rule o'er this wide realm; since right often ye accom-

$$
\text { plished My will, }
$$

Followed Me gladly, and were mild in your giving,

When I was plagued here with hunger and thirst,

Surrounded by frost; when I lay fettered

And oppressed in prison; oft there came to Me in My pain

Help from your hands: ye were mild in your hearts

And visited Me worthily." Then verily the crowd addressed Him again.

"My Lord most Good," quoth they. "When didst Thou languish in chains,

Oppressed by such needs, as Thou now tellest these

$$
\text { people, }
$$

As Thou, Mighty Master, dost mention? When hath any man seen Thee 
Oppressed by such needs? Why, Thou hast power over all peoples,

Over all treasures as well, whatever the children of men Have won in this world. Then spoke All-Wielding God to them once again.

"Whatever ye have done here," quoth $\mathrm{He}$, "In the name of your Lord,

In honor of God, have given of your goods

To the men who are the least of those standing here 'mid the many,

To such persons indeed poor for their humbleness, Since they accomplished My will - whatsoever ye gave unto them of your wealth,

Ye have done for honor of Me. Your Lord Himself hath received it,

The help did come to the Heaven-King. Therefore the Holy

\section{Lord}

Will reward your belief: He giveth life everlasting unto

$$
\text { you." }
$$

Then the Wielder, the Lord, will turn to those at His left hand,

To those men, who are damned, saying that they must pay for their deeds,

These folk for their wrongs; "Now shall ye fare From Me," quoth $\mathrm{He}$, "accursed to eternal fire, Fare to the fire made ready for foes of the Lord, For the folk of the Fiend for their foul works of sin, Since ye have not helped Me, when hunger and thirst Did torment Me most terribly; tortured My mind, I went without clothing: so great was My need, For I had naught of help when I was held bound, Locked into limb-fetters, and lay taken in illness, By serious plagues; for in My sickness ye never Did will to visit $\mathrm{Me}$ - nor was I of such worth unto you, That ye thought of Me ever. Therefore will ye suffer In hell in the darkness there." Then the horde of the people again spoke to Him: 
"Well, All-Wielding God," quoth they, "Why wilt Thou speak so 'gainst the folk?

Say such words 'gainst the many? When hast Thou ever had need of men

Or of the goods of mankind? Through Thy giving alone do they own it,

The wealth of this world." Then All-Wielding God speaketh again.

"When ye have scorned," quoth $\mathrm{He}$, "the poorest of the children of earth,

The least among men; have considered little

These men in your hearts; in your hearts have let them be hated,

Have denied them your love: then ye did likewise unto your Lord,

Denied Him your wealth; therefore All-Wielding God, Your Father, refuseth to take you; but ye must fare into the fire,

Go down into the deep death and there serve the devil, The evil Fiend, since thus ye acted before."

After these words $\mathrm{He}$ parted the people in twain, The good and the evil; and the damned ones did go Down into hot hell - they were troubled of heart There they were punished, received pain never ending, These men who were damned. He doth lead them thence, The High King of Heaven, leadeth the purified host Into long-lasting light - there is life everlasting: God's realm is made ready for all of the good.

\section{LIV}

So I found out that with His words the All-Wielding God Did tell unto His warriors about the turn of the world, How it fareth on, as long as the bairns of the folk May dwell therein, but how in the end it shall Glide away and be lost. He also said unto His disciples In words of truth: "Why, ye all wit," quoth $\mathrm{He}$, 
"That two nights from today the time will come, The paschaltide of the Jews, when the people must serve their God,

These men in the temple. It cannot be turned aside,

That the Son of Man be sold to the multitude, Full of strength though $\mathrm{He}$ be; and be struck to the cross, Enduring tortures most monsterious." Many thanes were there, too - men

From the south gathered together, a grim-minded folk, Clanships of Jews who were come to give service to God. Those learned in writing, the rabbis were come Among the crowd of the men: there were considered the wisest

Among the multitude of mankind assembled, A strong clanship. There was Kaiphas, too Bishop was he among the folk. They spake about God's Bairn, How they would slay Him, who was free from sin, Told how they could not touch Him on this holy day Among the multitude of the men, "Lest the many people, The hordes be aroused, since the host is willing

To stand and to battle for Him. In stillness we should Entrap Him, His life, so that the folk of the Jews Will not rise up in rebellion on this holy day." Then Judas came forward to him, the disciple of Christ, One of the twelve, to where the aethlings did tarry, The clanships of Jews; quoth that he indeed

Could give them good counsel, "What will ye pay me?" quoth he,

"What treasure, reward, if I should turn that Man over to you

Without rebellion or battle?" Then the hearts of the men became

Joyous, those of the folk: "If thou would'st do so," quoth they,

"And keep well thy word, then hast thou the right To ask for whatsoever of goodly wealth

Thou dost wish from this folk." Then the men who were there 
Put at his disposal pieces of silver, Thirty together; and he to the gathering did speak Insolent words: that for this he would yield his Master unto them.

Then he turned from the men; evil of mind was he, and disloyal.

He did calculate when the time would come unto him, That he might betray Him to the evil men, To the folk of the foe. For the Peace-Bairn of God, The True Wielding Christ well knew He must leave this world,

Give up the dwellings of men and return to the realms of God,

Fare to the ancient fief of His Father. Never have

The children of men seen more love than $\mathrm{He}$ bore to those men,

To His disciples good. He prepared a guest meal for them And sweetly did bid them sit, and said unto them Many a word most true. The day strode to the west, The sun to its setting. Then He Himself did bid them, The Wielder with His words, that they bring Him water, For His hands clear water; and there the Holy Christ did rise

At the feast, the Good Lord, and the feet of His followers $\mathrm{He}$ washed with His hands, and wiped them thereafter with towels,

Dried them most carefully. Then unto his Lord Christ Simon Peter did speak. "Methinks 'tis no seemly thing," quoth he,

"For Thee, my Master so Good, that Thou shouldst be washing my feet

With those, Thy most holy hands." The Lord gave reply unto him,

The Wielder then with His words. "If thou hast not the will," quoth $\mathrm{He}$, "To accept this thing, that I wash thy feet With such love indeed, as I do for the others, 
These men, through My love, then mayest thou not share with $\mathrm{Me}$

The kingdom of Heaven." His heart was then changed

For Simon Peter. "Thou Thyself wieldest power," said he, "My Lord so good, lo, over my feet and my hands And my head as well, to wash them all with Thy hands, O Ruler, if henceforth I may have Thy grace And such part of Thy kingdom of Heaven as Thou, Lord Christ,

Would'st grant unto me in Thy goodness."

The disciples of Christ, those earls, suffered His service

With patience, those thanes, whatsoever Mighty Christ, Their Liege, would do unto them, out of love, and $\mathrm{He}$ thought to do

A thing even greater for the children of men.

\section{V}

\section{The Peace-Child of God}

Did go to sit once again among the people and gave unto them

Much long-lasting counsel. Then was the light come, The morning come to mankind. Almighty Christ

Then greeted His subjects and asked them where they intended

To prepare for the feast on this festive day, Where He would hold, would keep this holy tide Himself with His disciples. Then He hight them, His men, Seek out Jerusalem: "When ye come there," quoth He, "Within the city itself, there will be great confusion, A mighty seething of men - ye will see a man Carrying there in his hand a cup of clear water. We shall follow him into whatsoever garden ye do see him go;

And unto that lord who owneth this house Ye yourselves shall say that I have sent you hence 
To make ready My feast. Then will he show you

A goodly house, a high upper hall

Hung over with brightest array. There shall ye busy

Yourselves with My meal. There I shall most certainly

Myself and My disciples, too." Then straightway thereafter

The servants of Christ set out on the way to Jerusalem, And they did find there all things even as $\mathrm{He}$ had said

With true word-tokens. Nor was aught truly changed.

They made ready the feast there, and right soon the Son of God,

The Holy Christ was come to the house

Where they should accomplish the custom there of the land,

Following the bidding of God, as it was for the Jewish folk

Ancient custom and law from time immemorial.

On the evening All-Wielding Christ did go

To take His seat in the hall; and He bade His disciples

Come unto Him, the twelve who were truest to Him, These men most loyal to Him in their minds

Both in words and in ways. Well did He know

The thoughts in their hearts, our Holy Lord -

He greeted them over the banquet. "I yearn indeed,"

He said, "to sit together with you

And partake of the feast, share the Passover

Of Jews with you, My beloved. Now must I tell unto you

The will of the Lord, that in this world no longer

May I enjoy meat with mankind before it must be fulfilled,

The kingdom of Heaven. For Me there is at hand

Both torment and torture, which I must truly endure

For the people, this land-folk here." So did He speak to

His thanes,

The Holy Lord, and His heart was grieved,

His spirit darkend with sorrow, and to His disciples

He spoke, 
The Good Man to His faithful: "Why, I give unto you the kingdom of God,

Give you the light of Heaven, and ye give unto $\mathrm{Me}$

Most sweetly your thaneship. But now ye wish not to fulfill this,

But waver far from the word. Now verily I say unto you

That one of your twelve will become untrue,

One will sell Me among the kinship of Jews,

Will sell Me for silver, and will take such riches,

Such precious treasure; and give his Lord in return,

His sweet, his beloved Liege. But great sorrow shall come unto him

From that deed, and much pain. For he shall perceive them, The Weird Sisters, and shall see the end of his care.

He shall know most truly that it would be a far sweeter thing,

A far better one, if he had never been born

To live in this light, than that he take pay

For evil deeds and wrongful advise."

Then each earl began to look around at the others,

To gaze about sorrowfully, for they were sore of soul

And troubled indeed of heart; they heard their Lord there

Speaking words of lament. They were worried

To which of the twelve He would now tell

That he was the miscreant, the man who had bargained

With the people for the pieces of silver. Nor was it simple for any person,

For any thane to confess such a crime,

Such a sinful mind; but each man denied it -

And all became fearful and dared not ask

Until Simon Peter, though he himself dared not speak -

This worthy man did make motion

To John the good: to the Bairn of God

He was in these days the dearest one,

The one most beloved, and Holy Christ gave him leave

To rest in His lap, to lie against His breast,

And on it to lean his head; there heard he so many a

holy mystery, 
So many deep thoughts; and to his dear Lord he did speak And began to question Him. "Who shall that be, my Liege?" Quoth he, "Who would sell Thee, the Richest of Kings, To the folk of the foe? Full anxious we are, O Wielder, to know." He had ready His words, The Holy Christ: "See thou into whose hands I here Give of My meat before these men: he hath most wicked thoughts,

Beareth great bitterness of mind: he shall deliver $\mathrm{Me}$ into bonds,

Into the power of the foe, where they shall deprive $\mathrm{Me}$ of My age,

Shall destroy My life." Thereafter He did take

The meat before the men and gave of the meat unto that mean scoundrel,

Into Judas' hand, and He spoke unto him,

He Himself before His disciples, and He straightway commanded

That he fare far away from the folk. "Do as thou thinkest," quoth $\mathrm{He}$,

"Do as thou needst must do; no longer mayest thou

Hide thy will and intent - thy Weird is at hand,

Thy time draweth near." When the troth-breaker

Did take of the meat and with his mouth did eat thereof, The power of God did forsake him, and the Fiend did enter

Into his body then, that loathsome wight;

And Satan was bound more sorely to him,

Bound hard 'round his heart, since the help of God

Had left him here in this light. To those who change lords

Under this heaven: to such woe will indeed come.

\section{V I}

Then setting out from there and thinking up evil, Judas did leave; against his Liege this thane Harbored great grimness of heart. It had grown very dark, It was deep in the night. Now the Son of the Lord 
Tarried still at the feast; and for His disciples there The Wielder did bless both the wine and the bread,

The Holy King of the Heavens; and with His hands He did break it

And gave it to His disciples and gave thanks unto God, Grateful unto Him, who created all that was there, The world and its winsomeness; and He spoke many a word:

"Believe ye this clearly," quoth He, "that this is My body

And My blood as well. I give both unto you

To eat and to drink. This I shall give on earth,

Shall spill and spread onto it, and shall ransom you

To the realms of the Lord and to life everlasting

In the light of Heaven. Remember ye ever

And follow ye that which I give unto you at this feast.

Make it known unto the many, for this is a mighty thing.

With it ye shall honor Him, who is your Lord.

Hold this to My memory as a holy token,

So that the children of men will cherish and keep it,

All men in this mid-world: that through My love I have done so,

Through the grace of the Lord. And think ye ever

How I have bidden you to keep firm this brotherhood,

To have fastness of mind, much love in your hearts, so that the children of men

Over the whole of the earth will all understand

That ye are most truly the disciples Mine.

I shall also make known unto you how a fierce, wily Fiend,

A sword-strong foe shall tempt your spirits, Satan himself. He cometh to ensnare

Your souls most boldly. Straightway must ye make steadfast

The thoughts in your breasts. By your prayers shall I stand,

So that the mighty Fiend may not cause your minds to become doubtful, 
So that I may help you against the foe. Once he came hither to tempt Me;

But his desire sufficed not one whit, His lust for My body. Nor will I longer conceal from you What trials now lie straight ahead for you:

Ye shall be disloyal to $\mathrm{Me}$, ye disciples Mine, Disloyal to your thaneship before this dark night Leaveth the land-folk and the light cometh once more, The morning to mankind." Then the minds of the men Became dreary, their hearts sore indeed.

They were troubled of spirit, and for their Lord's words Most sorrowed and grieved. But Simon Peter, The thane, did speak words of solace to the folk, For love of his Lord. "Though all this land-folk," quoth he,

"Though all Thy disciples deny Thee, still do I gladly Suffer all pain, all sorrow for Thee.

I am ever prepared, if God doth permit me, To stand straight and firm as a shield unto Thee. Though they close Thee deep in their dungeons, Though the land-folk lock Thee away, there is doubt so little

But that I would bide with Thee in Thy bonds, Lie with Thee, my so beloved Lord, if they lie in wait To snuff out Thy life with the hate of the sword's edge, O my Master most Good; then shall I gladly give up my

life

For Thee in the play of weapons, nor verily shall I

Ever avoid it, as long as mind

And strength of hand are still mine." Then His Lord spoke again unto him.

"Why, thou presumest in thyself," quoth $\mathrm{He}$, "an unswerving loyalty.

A steadfastness so great! Oh, thou hast the soul of a hero

And good will as well. Yet may I tell unto thee how it will hap, 
That thou shall'st become so wavering of heart, as thou now canst not ween:

That thou shallst deny Me, thy Lord, three times,

Before the crow of the cock, acknowledging Me not as thy Liege,

But thou shallst renounce My protection." Then again the man did reply.

"If in this world," quoth he, "it will ever so come to pass,

That I should have to face death together with Thee, Have to die in splendor, still that day will never arrive When I would deny Thee, my most dearly loved Lord, Of my own will before these, the Jews." All the disciples spoke likewise,

That they would suffer with Him at the tribunal there.

LVII

Then the Wielder Himself bade them with His words, The High King of Heaven, that they let not their hearts doubt,

Hight that they not want ... deep thought ${ }^{1}$

"Let not your hearts be laid low by the word of your Lord, Nor fear ye too much. I shall seek Our Father Myself And shall send the Holy Ghost from the kingdom of Heaven. He shall be consolation and succor both unto you, Reminding you in His speech of the many things I have taught

Unto you with My words. Wisdom He will give unto you In your hearts, a joyous teaching, so that ye shall henceforth accomplish

The word and the work which I have shown unto you in this world."

The Mighty Son then rose, Christ Savior, In the temple there, and with His thanes $\mathrm{He}$ fared forth,

1 Lacuna in MS. 
He Himself on that very same night. Christ's disciples

Went sorrowing and grieving most sadly,

Troubled of heart. Then He climbed up a hill -

The Olive Mount was it called: there 'twas His custom

To go with His followers. Full well did Judas know this,

The man with his mind aimed to ruin: for on this mount he was often with Him.

Then God's Son did indeed greet His disciples.

"Ye are now so saddened," quoth $\mathrm{He}$, "since ye know of

My death.

Now ye are grieving and groaning, while the Jews are gay,

While the many are merry and happy of mind,

While the world is in rapture. Yet this will all come to an end,

Will cease most swiftly. Then will they be sore of heart, Grow mournful of mind, and ye may rejoice

Until that day everlasting; for your end and a turn

Of your fortune never cometh: therefore may ye henceforth

Not regret My words nor rue My coming." Then He bade His retainers

Come on the mountain; quoth that He wished them to climb

Higher up with Him upon the hill-cliff, And He hight that three of His thanes go with Him, Jacob and John and Peter the Good, Loyal thanes three. And they did so go

With their Liege most gladly. Then the Son of God, Upon the hill, did bid them bend their knees in prayer, Bade that they greet God and entreat Him greatly That He hold in check the strength of the Tempter The will of the wicked, so that the worker of wrong, The devil, could not bring their minds to doubt. And also the Lord Himself for prayer Did bow with bent knee, the Brightest of Kings, Kneeling forward to earth; and to the Father of all Earthfolk

He cried aloud, spoke lamenting words 
In His sorrow; for His spirit was grieved And His heart was moved by His humanness.

His flesh feared indeed; tears fell from Him, His dear, precious sweat did drip, even as blood doth drip,

Doth well from a wound. Within God's Bairn

A battle was raging between body and spirit.

The one was ready for the road beyond,

The spirit for the kingdom of God, while the other stood yammering,

The flesh of Christ; and fearful of death,

It sought not to give up the light. Ever He cried to the Lord,

Ever more did He call unto the Almighty,

To the High Father of Heaven, to the Holy God,

To the All-Wielder ever with His words. "If mankind," quoth $\mathrm{He}$,

"Cannot be saved. except that I give

My own precious blood to the bairns of the people

To torture most terribly - if this be truly Thy will,

Then will I choose to drain it: I take in my hands the chalice,

Drink it down to the dregs, my Lord, dear Liege,

Mighty Master and Shielder. Look Thou not now down on $\mathrm{Me}$,

On the good of My flesh. But I shall fulfill

Whatsoever Thy will be: for Thou wieldest power over all."

Then He went to that place, where He had left His disciples

Biding upon the mountain; and the Bairn of God

Did find them in troubled sleep; for their hearts were

$$
\text { sore, }
$$

That they should be parted from their beloved Liege.

Such should be the mind-sorrow of every man

Who must forsake and leave his beloved lord,

Giving up one so good. Then He did go to His disciples, spoke unto them;

The Wielder did wake them and greet them with words. 
"Why do ye wish to sleep?" quoth He. "Why do ye not watch But a little time here with Me? That Weird is at hand, That it shall so come to pass, even as $\mathrm{He}$, God the Father,

The Mighty, hath marked it. There is no doubt in My mind;

My spirit is most ready to make done God's will, Is prepared to fare on His way. But My flesh is still troubled,

My body still holds Me bound. It is loathe to bear, To endure such suffering. But I shall accomplish

My Father's will. Have ye firmness of heart!"

He did go then up on the other side

Of the mountain in order to pray -

The Glorious Lord - and many a good word

He did indeed speak there. God's angel then came

Holy from Heaven and made firm His heart,

Made Him bold for the bonds. He bided there ever, Zealous in prayer, and to His Father He cried,

To the Wielder with His words. "If it cannot be other-

$$
\text { wise," quoth } \mathrm{He} \text {, }
$$

"O Lord most splendid, except that I suffer

Great torture and torment for the folk of mankind, I shall truly

Await then Thy will." And He went again thence

To seek His disciples. He found them sleeping

And called to them curtly. And again $\mathrm{He}$ went thence

A third time to pray. And the King of All Peoples,

The Son of the Lord, spoke with the selfsame words

To His All-Wielding Father, as He had done before.

Most zealously did Savior Christ

Remind the Mighty One of the good of mankind;

And went then again to His disciples, and straightway $\mathrm{He}$ spoke unto them.

"Sleep ye and rest," said He. "Now will he straightway come, Come with a force, he who hath sold Me, sinless as I am, And hath received silver therefore." The disciples of Christ 
Awakened after these words, and they beheld war-men coming, Climbing up the mountain with a great commotion, Wrathful weapon-bearers full many.

\section{LVIII}

Judas rightly did lead them,

Man hate-filled of heart. After him the Jews did go marching,

The folk-clans of the foe. In their midst they carried fire,

Lights in lamp-vessels; and they led forth torches, Bright burning down from the city, as they began most

$$
\text { eagerly }
$$

To stride up the mountain. This spot Judas knew well, The one to which he should lead the land-folk all. As they now fared to the spot in front of the folk, He said unto them as a sign, lest they seize by mistake Some other man: "I shall first go to Him," quoth he, "Shall kiss Him and say: that is Christ Himself! Then shall ye seize Him with the strength of the crowd;

Shall bind Him up there on the mount and bring Him down to the bastion,

Lead Him down 'mid the land-folk: His life hath he forfeited

With His words full well." And the people went, Until they were come to the Christ Himself -

The grim folk of the Jews, to where He stood with His followers,

The Lord Most Glorious, biding his god-sent fate, The wonderous time. Then Judas went toward Him, Man without troth, and unto God's Bairn He nodded His head and here spoke to his Lord, Kissed Him, Mighty Christ, carried out his word, Pointed Him out to the people, as he had promised before. The Lord of All Peoples bore all with His patience, The Wielder of World; and with His words He did speak unto him, 
Asked him most boldly: "Why hast thou come to Me with this host?

Why dost thou lead this land-folk to Me? And to this loathsome crowd

Thou sellest Me with thy kiss, among the clans of the Jews

Betrayest Me to these many?" He went to speak to the many,

To the other people, and to ask with His words

Why they were come to seek Him so zealouly here

With their thralls in the night. "To whom do you wish to bring need and distress,

To some one of mankind.?" Then once more the many did speak unto Him

And said that they had been told that the Savior did tarry Here high on the hillside. "He who hath caused this unrest Amid the Jewish folk and calleth Himself The Son of God. We came here to seek Him, Are most anxious to find Him: He is from Galilee-land From the city of Nazareth." When Saving Christ Said unto them in sooth that it was He Himself, The folk of the Jews became sore afraid.

Frightened and shocked were they, so that they straightway fell back,

Each and all, and sought the earth: at the same time All the host did retreat. They could not resist The word and the voice of the Lord; yet were there some warlike men.

These ran up the hillock; made firm their hearts, Bound fast the thoughts in their breasts; and bitterly

$$
\text { raging, }
$$

They surrounded Christ Savior. There stood the wise men

Grieving greatly - Christ's goodly disciples, Before this most dreadful deed; and to their Dear Lord they did speak:

"Were it now Thy will," quoth they, "My Wielder, My Liege, That they shall slay us with the spear-point here, Shall wound us with weapons, then would nought be one whit as good, 
But that we might die here for our Dear Lord, Pale in expiring. Then plenteously wroth grew he, The swift swordsman, Simon Peter.

It welled up with his heart, so that not a word could he speak,

So sorrowed his soul, since they were about to enchain

His Beloved Lord there. Bloated with anger, the bold-minded

Thane strode ahead, stood before his Liege,

Hard by his Lord; nor was his heart e'er in doubt,

Fearful within his breast, but he drew his bill,

The sword at his side, and with the strength of his arm

He struck the first of the foe standing before him,

So that Malchus was marked by the knife

On his right side, slashed by the sword's edge.

His hearing had been hewn: sore was the hurt 'round his head,

So that sword-gory, cheek and ear in mortal wound Burst asunder, and blood did spring forth,

Welling up from the wound. Then was the cheek indeed scarred

Of the enemy's leader. Those around stood away,

Dreading the bite of the bill. Then spake God's Bairn

Himself to Simon Peter, said that he should put his sword,

The sharp one, back in its scabbard. "If I truly cared," said $\mathrm{He}$

"To wage conflict against this crowd of the warriors, Then would I remind Him, the Glorious, the Almighty God, The Holy Father in the Kingdom of Heaven, That $\mathrm{He}$ send hither to $\mathrm{Me}$ a host of His angels, Wise in warfaring; these men could indeed not withstand Their weapon-strength ever. Nor could such a host of warriors

Stand against them, though gathered together in groups.

Still could they not save their lives. But the All-

$$
\text { Wielding Lord, }
$$

The Father Almighty, hath marked it otherwise:

We are to bear all the bitterness, whatsoever these people bring unto us, 
Nor shall we be angry nor rage 'gainst their strife:

For he who doth practice the hatred of weapons,

Who gladly partaketh in grim spear-grudges -

He again is slain by the sword's edge,

Doth die in his own blood. We must not destroy

One whit with our deeds." Then $\mathrm{He}$ went to the wounded man.

With skill He set the flesh-seams together,

The head-wounds all, so that it was healed straightway,

The bite of the bill. And the Bairn of God

Spake to the angry throng. "Methinks 'tis a wonder great," quoth $\mathrm{He}$,

"If ye have wanted to do harm unto Me,

Why did ye then not take Me, when I stood in the temple,

Among your folk and did tell them full many true words?

The sun shone, the day's dear beam, and ye did want to do

Naught to harm there in this light; but now ye lead your

landsmen

To Me in the night, as one doeth unto a thief

Whom one wishes to seize - some scoundrel and wretch

Who hath forfeited life." Then the folk of the Jews

Grasped at God's Son, the grim-minded host,

The persecuting crowd. The people piled 'round Him,

The enraged horde of men - they saw not their wrongs -

They held Him fast, threw His hands in chains,

His arms and fingers in fetters. Such frightful torment

He needed not have stood, nor such grievous suffering,

Nor have endured such anguish. But He did so for this host,

Since He wanted to save the children of men,

To fetch them from hell to the kingdom of Heaven,

To the wide-flung wealth; therefore $\mathrm{He}$ reproached them no whit

For that which they would do unto Him in their hatred and anger. 
Then the angry folk of the Jews did become insolent, The host most haughty, since they had Holy Christ And could lead Him away in limb-bondage, Take Him forth in their fetters. And the foe went again From the mount to the town. And God's Mighty Bairn Did go 'mid the host with His hands all bound, Drear and sad, down to the dale. For His dearest thanes Had broken their troth, as He Himself had foretold. But it was not for fear that they forsook Him, God's Bairn, their Beloved, but so long before there had been

The word of the prophet, that it would indeed be thus.

Therefore they could not avoid their own deeds. And after the crowd

Went Peter and John, those two men well-known, And followed from afar. Full anxious were they To know what the grim-minded Jews meant to do with God's Bairn,

To their Lord most Dear. When they were come down to the dale

From the hill to the burg in which was their bishop, The temple's holder, these haughty men did lead Him These earls, behind a fence. A great fire was there, There were flames in the foreyard, made nearby for the folk,

For the warrior crowd. They went there to warm them, The landsmen of Jews, and they left God's Bairn Waiting in chains. There was a great racket, The noise of the insolent. Since John was known To the highest one there, he could push inside with the host,

With the throng through the yard; but the best of all thanes, Peter, still stood outside. The portal's warder would not permit him

To follow His Lord, till he begged a friend, 
Until John begged of a Jew to let Peter go

Forth to the foreyard. A woman full of deceit

Did slip up to him there: she was a handmaid

Of one of the Jews, of her lord; and this unlovely girl

Did speak to the thane. "What, thou mightest be," quoth she, "a man

From Galilee, disciple of Him standing yonder

With His arms firmly fettered." Then fear overtook

Simon Peter straightway, and his mind became slack,

And he said that not one word of the wife had he understood,

Nor was He a thane of that Leader ever, of that Lord.

He avoided Him in view of the many, said verily he knew not that Man.

"Thy talk is senseless to me," said he. Then God's strength,

The Lord's power did leave his heart. And leaving, he did

go

Forth amid the folk, until he came to the fires;

He went there to warm him. There also a woman began

To load loathsome words unto him. "Here may ye look on your foe," cried she,

"This is all clearly a retainer of Christ,

A disciple of Him Himself." Then straightway there did come nearer

To him men of the foe. And the bairns of the Fiend

Did question him of what clan he was:

"Thou art not of these burghers," quoth they. "From thy bearing we see that,

From thy words and thy ways, that thou art not of this world-folk,

But art from Galilee come." Yet he would not admit it,

But stood there denying and swore a strong oath

By all that is true that he was not of that tribe.

His words had no power: it was to come to this pass,

As $\mathrm{He}$ who rules mankind had so marked it indeed

In this world. Then came to him also a cousin

Of him whom he had hewn with his bill,

With his sword's sharpness; and said that he had seen him there 
"High on the hillock, there where we bound the hands

Of thy Lord in the grove, in the tree-garden there,

Fastened His arms with the fetters." Then for the fear in his heart

He again denied his dear Liege, quoth that indeed he would forfeit his life,

If there was any man here on this earth

Who can say in truth that he was of that tribe, That he followed His path. There for the first time The crow of the cock did commence. And Holy Christ, The Best of All Bairns, who stood there bound, The Son of the Lord Himself, did look to Simon Peter, Saw that earl over His shoulder. Then Simon Peter

Felt sadness within him and his spirit was sore.

Filled with hurt was his heart, and most grieved was he. So troubled was he, that he himself had so spoken before, And he remembered the words then which All-Wielding Christ

Had said unto him; that in this swarthy, dark night, He was to deny Him, his Lord, three times, Before the crow of the cock. Bitterly this came up in his breast,

Welled up with him; and angry of heart he went away:

The man left the many. With care in his mind And deeply sorrowed, he wept at his sinfulness, At his own words, and there came welling up Hot tears from within him for the grief in his heart, Bloodily bursting up from his breast. For he thought Never to atone for his sins nor come again to his Master, To the grace of his Lord. No one hath since grown so old Who ever did see a man rue more sorely His own words and his sins and to bewail them so, Lamenting most loudly. "Woe, Mighty God, O my Lord," quoth he,

"Woe that I have forfeited myself, so that for this world, This life I may no longer be thankful. If in my old age I must renounce Thy grace and the realms of Heaven, 
Then my Ruler, my King, be there no thanks unto me, My Beloved Liege, that I was born to this light.

I am now unworthy, O Thou, my Wielder, That I may thus fare along with Thy followers, Sinful amid Thy disciples. I myself shall avoid them In my heart and my soul, since I have spoken such sin." Thus the best of all men grieved bitterly indeed. He rued most deeply that he had denied Him there, His Beloved Lord. But the bairns of the land-folk, Of mankind should not wonder why God so willed it, That such a beloved man should suffer such sorrow, That he should deny his Lord so disgracefully For the word of a servant maid - he, this swiftest of warriors

Deny his Dear Liege; it was done for all those of mankind, For the good of the children of men. He wanted to make them the first,

The highest over His household - He the Lord Holy:

He let it be known how little strength hath

The heart of man without God's might.

He let him sin so that later he might

Better believe them, the people, how precious it is

For each man indeed, when he hath done evil, That he be absolved from his wicked deeds,

From his wrongs and his sins, as he is absolved by God Himself,

The Ruler of Heaven's Realms, from his hurtful wrong.

LX

Therefore is a man's boasting of but little avail The pride of his youth: if then God's help doth forsake him,

Because of his sins, then is that man straightway Fearful of thought, though he first uttered threats And boasted of his battles and of the broad strength of his hand - 
This man of his might. This was marked in that marvelous, That best of all thanes, when at that time the holy help Of His Master forsook him. Therefore no man should boast All too much of himself, since then often hope And will do forsake him, if All-Wielding God, The High King of Heaven, doth not strengthen his heart.

But the Best of All Bairns did wait and did bear His bonds

For the sake of mankind. Many of the Jewish folk

Did come and surround Him and speak such mockery

And held Him to scorn, as He stood there chained

And enduring most patiently what the people did unto Him, What loathsome grief these land-folk. Then was the light come again,

The morning to mankind. Many were gathered, Wide hosts of the Jews. Wolf-minds had they, Evil hearts as well. Their book-learned ones, Many men together, gathered at morning-tide, Angry and hardened and longing for evil, Wishing for wrong. They went in groups together, The men to consult; and they began to consider How they would accuse the Mighty Christ of sin With false witnesses and with faithless men Accuse Him indeed through His own spoken word, So that they might torment Him with tortures most great, Dealing out death unto Him. But on that day they could Find no false witnesses, ones who feared not To deal out such pain, and to condemn Him to death, Release Him from life. Then at last there came forth From the crowd two men without truth and began to tell against $\mathrm{Him}$,

Said that they had heard Him Himself say That He could tear down the temple of God, The highest of all houses, through the strength of His hands;

And through His craft and His might could erect it again On the third day hence, as no other man could ever thus do. 
He was silent and suffered. Never could a folk speak, A people utter such lies, that $\mathrm{He}$ would verily Have avenged them with words of evil. Then there arose from the host

A man baleful of thought: bishop among the folk, A prince of this people - and put such question to Christ,

Exhorted Him strongly with solemn oath, Greeted Him thus in the name of God and bade Him eagerly To say unto him, whether He were the Son Of the Living God: He who created the light, Christ, King Eternal. "We cannot see one whit of this From Thy words or Thy works." Then verily again the True,

The Good Son of God did reply: "Thou sayest it now before

Sayest it truly, that it is I Myself. these Jews,

But these landsmen do not believe $\mathrm{Me}$; and hence will they not release $\mathrm{Me}$,

Nor are they worthy of My word. Now verily I say unto you

That ye shall still see $\mathrm{Me}$ sitting on the right side of God,

Radiant the Son of Man in the might and strength

Of the All-Wielding Father, and coming again down here Through the clouds of Heaven and dealing unto all the kith of mankind

Such judgments with His words, even as they worked and are worthy thereof."

Then was the bishop wrathful and bitter of heart,

Sorely enraged at these words; and he rent his raiments,

Tore them before his breast; "Now need ye bide no longer," quoth he,

"Ye people, wait for a witness, now that such words, Such blasphemy hath come from His mouth. Many men have now heard it:

Warriors here in the temple, that He told of His mightiness, 
Said that He was the God. Well then, ye Jews, What doom will ye deal Him? Is He now worthy of death For such words?"

The war-men all spoke,

The folk of the Jews, that He had forfeited life,

Was worthy of punishment. Yet not for His works was it done,

That the Jewish folk there in Jerusalem

Condemned Him to His death, Him who had done no sin, The Son of the Lord. Then the land-folk of Jews

Did boast of their deeds, how they could do God's Bairn, Him held in bonds, the most harm indeed.

The crowd surrounded Him and struck His cheeks, the side

Of His head with their hands: unto Him they did this in mockery and scorn,

The crowd of the foe; covered Him with their malice And their blasphemous speech. And the Bairn of God Stood firmly amid His foe. His arms were in fetters; He endured most patiently what the people Brought unto Him of bitterness there. He bore no anger Against this riot of men. Then wrathful men Did take Him so bound, that Bairn of God, And they led Him there to where the folk-throng's The people's judging-place was. There thanes aplenty Surrounded their leader. He was the envoy of that lord Of the city of Rome, who ruled over all realms;

He was come from Caesar, was sent to the clans of the Jews, To govern their kingdom: he gave them counsel. Pilate was he called, and he was a man from Pontus, Born of that clan. He had collected a great crowd, A multitude of the people at the judging place.

This faithless horde of the Jewish host Did give Him up - Him, Son of God, To the folk of the foe; quoth that He had forfeited His life 
And that one should reward Him with the weapon's edge, With the sword's sharpness. Still the crowd of the Jews cared not

To throng into the law-house itself; but the land-folk did remain without,

And spoke from there to the many within. Into this mob they wished not to go,

Not go to that foreign man, so that they need not hear these unrighteous words

On that day, nor hear one whit of the wrong being dealt. But said it was their wont to hold the holiest of times, The purest, their Passover. Pilate received The Wielder's Bairn from the wicked sinners, Received Him, the Sinless. Then sorely troubled Was Judas of mind, when he saw His Master Surrounded to death; and his deed he now began To rue in his heart, that he had sold Him, His Lord without Sin. He took the silver, Took there the thirty pieces that they had given to him in return for his Liege.

And he went with them to the Jews and told them his grim, wicked deed,

Said unto them his sin; and the silver he offered

To give back gladly. "So grievously," quoth he, "Have I sold it, the blood of my Liege, my Beloved, That I ween that to me it will be of no worth." But the host of the Jews would not take it, but hight him henceforth

To let such a sin be his own care and concern, That e'er he had done against his Lord.

"Thou thyself look to that," quoth they. "What hast thou to seek among us?

Do not thou place shame on these people." Then presently

$$
\text { Judas }
$$

Did again go thence to the temple of God

Most sorely grieved, and he threw the silver

Inside on the altar, nor dared he own it for long. 
He fared forth in fear and the bairns of the Fiend Admonished him fiercely: the devil had seized The mind of this man; and the Mighty God was enraged, So that he, that wretch, did fashion a rope; And in order to hang him, did incline his head Through the death-choking noose, and chose his reward, The hard pangs of hell, those hot and most dark, The deep dale of death; since unto his Liege he had indeed been disloyal.

\section{X I I}

Suffering His bonds, God's Bairn still did bide, Did wait at the law-house until the land-folk About Him became all of one mind As to what terrible torture they intended for Him. Then the envoy of Caesar arose from the bench $\mathrm{He}$, come from Rome; and he went to speak angrily

To the crowd of the Jews, there where in the courtyard The many were milling about. The multitude would not come Into the house on the Paschal day. Pilate began To question boldly about the folk of the Jews, Why this Man indeed did deserve His murder, Had reaped such punishment. "Why now are ye wroth, So hostile of mind to this Man?" They said that He had harmed them muchly,

Had done them great wrong. "The folk would not give Him over to thee,

If they knew not already that noxious $\mathrm{He}$ was and evil:

He hath forfeited His life with His words. Full many a one of the folk

Hath He seduced with His teachings, hath distressed these

$$
\text { people, }
$$

Caused their minds to doubt: that to Caesar's court

We need pay no tithe. That may we tell of Him

With truthful witness. Great words speaketh $\mathrm{He}$ also:

Doth say He is the Christ, King over that realm. 
With His bigness is He bloated." But then Caesar's envoy Did speak again unto them. "If He hath so openly

Done deeds of evil," quoth he, "among the multitude, Then take Him back among your folk; and if He hath forfeited His life,

Deal ye His doom, if He is deserving of death, As your age-old laws do order you."

Still at this time on this hallowed day, Quoth they, they could not kill with their weapons, Become murderers of any man whatsoever.

Then he turned away from the horde - that man, evilhearted,

The thane of Caesar, who was over his throngs, The envoy from Rome - and he ordered right quickly

That the Bairn of God be brought closer to him; and bluntly

And carefully questioned Him, whether He was King of this crowd,

Of this land-folk here. And the Son of the Lord

Had ready His word, asking "Whether thou speakest that for thyself,

Or whether for others, the earls here, have

Told of My kingdom?" Then truly the envoy of Caesar

Spoke again, evil and insolent of mind, as he wrangled

With Christ Wielder there in the temple. "I am not," quoth he,

"Of this kingdom, of the Jews, am no kin of Thine, No kith of these men, but the many have consigned Thee to me,

Thy landsmen, the folk of the Jews have given Thee fettered Into my hands. What harm hast Thou done, That so bitterly Thou must suffer Thy bondage?

Torture from Thy own true kin?" Then Christ did tell him again,

The Best of All Saviors, as He stood there bound Inside the temple. "My kingdom," quoth $\mathrm{He}$, "is not Of this hour, of this earthly life. If it were thus, 
My disciples would be standing strong against the strifeminded,

My followers, thanes resisting the throng.

Nor fettered, would I be given o'er to the folk

Of the hating, the Jews, into their hands

To be tortured most terribly. Truly was I born to this world

To make known unto you a testimony of truth

Through My coming. And that they well may acknowledge, Those men who have strayed from the truth: they may hear My word,

Understand and believe My lesson." Then the envoy of Caesar

Could not find a whit of fault with God's Bairn,

Not a word of deceit for which He was worthy

Of paying His life. Then he repaired once more to the people of Jews

To speak with them angrily. And he said to the many

Who hearkened most carefully, that he could find

No such blasphemous speech, that He should pay with His life,

Be worthy of death. Then dull-minded,

The Jewish folk did stand and accused God's Son

With their words and said that He had first stirred insurrection

And unrest in Galilee-land; and from there had repaired

Hither over Judea; and He caused hearts to doubt,

The minds of men, "and for that He deserves to be murdered,

Is worthy of death with the weapons's edge,

If ever a man was deserving of death for such deeds."

LXIII

The landsmen of Jews lamented loudly to him with their words,

Their hearts all hate-filled; then the high lord, The sly-minded man, heard them say unto him 
From which of the clanships Christ had been born, The Best of All Men: He belonged to a glorious band From Galilee-land - Christ the Good. There dwelt a great crowd,

A host of aethling-born men. Herod held there

A strong, goodly kingdom, which Caesar had given unto him, The mighty from Rome; and there he dealt justice, Practiced right 'mid the people, keeping the peace And dealing out dooms. On that day also

$\mathrm{He}$ was there in Jerusalem with his thanes and retainers

And came to the temple: that was their custom

That they held sacred the holy tide

The Passover of Jews. Pilate then bade That the soldiers take that Man in His chains, Take Him in His bonds, the Bairn of God, Hight that the earls bring Him to Herod, His hands held in fetters, since $\mathrm{He}$ was of that folk Over which Herod wielded power. The warriors accomplished The word of their lord. They led Holy Christ Forth in His fetters in front of the folk-leader. The Best of All Bairns who had ever been born To the light of the land-folk. In His limb-bonds he went, Until they did bring Him there where he sat on his bench Herod the king. A crowd of people surrounded him, Proud-minded warriors; a great will was within them To see Christ Himself, for they weened He would show them

Some token, as indeed He had done through His godliness Before the crowd of the Jews: He, Christ Great and Mighty; Then the folk-king did question Him - full envious was he,

Asked many a word and wanted to fathom

How His spirit inclined, what $\mathrm{He}$ minded to do

For the weal of men. There stood Mighty Christ, Was silent and suffered. He chose not to answer him, Herod, the folk-king, nor the earls of his following, Not with one single word. Then the wicked throng, 
The folk of the Jews stood there, and the Son of God.

They did worry and accuse Him wildly, until the worldking

Became enraged of heart, and his retainers as well:

In their spirits they scorned Him; for they saw the great might of God,

Of the Lord of all Heaven; and in their heart there was darkness

In the grip of sin. But the Son of the Lord

Endured their direful works, their words and their deeds, Suffered them all with a humble soul, All the wrongs they longed to do unto Him.

They ordered white robes wrapped around Him, 'round His limbs

In mockery; all the more He became for the men there, For the young ones, a jest; and the Jews did rejoice, When they saw how those held Him in scorn, Those earls overweening. Then Herod again, The king, sent Him thence to the other clanships.

He hight that a strong man should lead Him hence; and they spoke

To Him sinfully, heaped blasphemy on Him as He went in His bonds,

And they laughed in mockery. But His mind never doubted, But He suffered all with a humble spirit; He wished not to repay them for their wicked words, For their mocking speech and their scorn. They brought

Him inside the house,

Up in the palace, where Pilate was

In the judging place there. The thralls then did give The Best of All Bairns into the hands of the baleful, The murderers - Him without sin, as He Himself chose. He wanted to free the bairns of mankind from the bonds of death,

To save them from suffering. The foe stood around, Jews before the guest halls: the bairns of the devil Had stirred up the horde, so that they did not hold back 
From these grim, wicked deeds. Then he went forth, The thane of Caesar, and to the folk he did speak,

The harsh leader of hosts. "What, ye have sent Him here to the hall,

Sent this Man unto me in His bonds, have yourselves blamed Him,

That He hath brought ruin to right many folk,

With His lesson hath led them all wrongly. Now from these landsmen,

From this folk, I cannot find that He hath forfeited

His life, is guilty of aught. That was indeed all clear this day:

Herod, who knoweth your laws, your people, your landways, Could not in anger end His life on this day, Would not say He should die for any sin of His Should take leave of this life. Now before this land-folk

Shall I threaten Him with the law, shall urge Him with words, Shall better the thought in His breast, so that henceforth He may enjoy life among man." But the multitude Of Jews cried together, called with loud voices And eagerly hight that He be robbed of His life Christ killed with torture and struck on the cross, Tormented to death. "With His words He hath done it, Hath forfeited life! He sayeth He is the Lord, Truly God's Son. He shall now pay

For His evil speech; so our law is indeed writ:

That one buyeth with one's life such blasphemous speech."

LXI V

Then he who held sway o'er the folk became sore afraid, In his mind did fear mightily, when he heard the men say That they had heard Him speak thus themselves, Proclaiming in front of the clanships that He was God's Son.

Then the leader of hosts went back in the house, Into the judging hall and hailed God's Son 
With confident words and questioned what $\mathrm{He}$ was 'mid the clans:

"What kind of man art Thou?" quoth he. "Why concealest Thou Thy mind,

Hidest Thy deepest thoughts? Wist Thou that Thy life's destiny

Standeth so, even as I shall decide. Unto me have these folk,

These people of Jews given Thee to wield such power o'er Thee,

Either to slay Thee with the point of the spear,

To torture Thee unto the cross, or to leave Thee quick and alive,

Even as I myself deem it better

To act for my people." Then the Peace-Bairn of God spoke again:

"Thou wist most verily," quoth He, "that thou would'st wield, Wouldst have no might over Me, but that Holy God Himself Hath granted it unto thee. And those, too, have sinned more, Those who have sent $\mathrm{Me}$ to thee in their hatred,

Have sold Me, bound fast in these snares." There straightway thereafter

The grim-souled man would gladly have released Him, The thane of the emperor in front of the throng, if he could have but done so.

But they denied him his will with their every word The clan-folk of Jews. "Thou art not," quoth they, "Caesar's friend,

The beloved of thy lord, if thou leavest Him

To go hence sound and unharmed. That may still bring thee sorrow

And reprisal, too, if a one speaketh such words, Raiseth himself so high, and sayeth that he here holdeth The name of a kingdom, though Caesar ne'er gave it, $\mathrm{He}$ confuseth his world-realms and bringeth scorn to his word,

Mocking him in his mind. Therefore must thou avenge such wrongs, 
These insolent words, if thou hast worry for thy master's, For thy liege-lord's friendship. Then should'st thou reft

Him of life."

The duke now heard, how the aethlings of the Jews

Threatened him with his liege; therefore he went himself And sat at the judging place, where a great host of people Was gathered together, and hight Christ the Wielder Be brought there in front of the folk. The Jews then demanded

To see the Holy Bairn first hanging in torment

There on the cross; quoth that no other king

Would they have to oversee them, except for high Caesar

From the city of Rome. "He hath here his rule over us.

Therefore shalt thou not release Him; He hath spoken much harm unto us,

Hath done in His life through His deeds. Death shall $\mathrm{He}$ suffer here,

Punishment and the pangs of torture." The people of Jews

Accused Mighty Christ of so many,

Of such varied sins. He stood silent

There in His humbleness, and not a thing did $\mathrm{He}$ answer

To the wicked words. He wanted to ransom

All men with His life. Therefore He let the loathsome mob

Torment Him most terribly, as was truly His will.

Yet He had no wish to reveal all things openly

To the people of Jews: that He Himself was indeed God.

For if they verily knew that $\mathrm{He}$ wielded such might

Over the mid-world here, then their minds would grow fearful,

Be afraid in their breasts; then God's Bairn they'd not dare

To touch with their hands; and the kingdom of Heaven,

The greatest of lights, would never be unlocked to the bairns of mankind.

Therefore He hid it well in His mind and let not the children of men 
Know what they were working. Then Weird came nearer, God's glorious might, and that great midday

When they would cause to be done those death-torments. There lay also in bonds within the bastion

A notorious robber: in the realm he had

Committed murders aplenty and done manslaughter.

He was known as a mighty thief. Nor was there his like anywhere.

He was in chains because of his sins.

Barrabas was he hight, and here in the burg

This man was far known for his many misdeeds.

That was the land-custom of the kinfolk of Jews

That each year for God's love they could ask amnesty

On that holy day for some man doomed to die;

And that the leader, warder of bastions, would give him his life.

Then the duke began to question the gathering, The folk of the Jews who stood there before him

Which of the two they wanted to have freed, To beg for his life: "which are in bonds here,

In fetters in front of the clanships." Then the folk of

$$
\text { the Jews }
$$

Had stirred up all the poorer, the smaller men,

So that they asked for the life of the land-robber:

They demanded the thief, who in darkness of night

Had committed his crimes; and All-Wielding Christ

They tortured onto the cross. Then it became truly known unto all

How the people had dealt out their dooms. Then had they to accomplish this deed

And to hang Him, the Holy Bairn. In times hence that would bring

To the duke great trouble, when he truly knew

That the folk of the Jews loathed Christ Savior as their foe,

That they hated Him; and that he, Pilate, had hearkened unto them 
And had granted their will; for this he had evil reward, Punishment here in this light and for long ages after. He won great woe, when he later gave up this world.

\section{X V}

The Wrong-Doer soon grew aware of this, the greatest of scoundrels,

Satan himself, when the soul of Judas

Came down to the ground of grim, hot hell.

Then most verily he knew that it was All-Wielding Christ, The Bairn of the Lord, who stood there bound;

And most verily he knew that He wished to release

The whole world and its people from the pangs of hell

Through His hanging, leading them all to the light of the Lord.

Then was Satan indeed sore of heart,

Most troubled of mind; truly he hoped

To bring it about that the bairns of mankind

Would not rob Christ of life, nor torture Him on the cross.

But he wanted Christ to remain quick and alive,

So that the children of men would not be safe from hell, Safe from their sins. Satan hied himself hence

To where was the house of the host's leader

Within the bastions. To the bride here openly, To the wife within the weird Fiend began

To reveal great wonders, so that with her word-help

She would cause it to be that Christ, Lord of Men,

Could remain 'mid the quick - for already $\mathrm{He}$ was destined to die -

For he knew most truly that He would take from him the power

So that he would no longer own so much in this mid-world here,

O'er this wide, wide earth. The wife became fearful. Sorely troubled was she, since these visions did come unto her 
In the full light of day through the doing of him Who was hidden by a helmet of magic to make him unseen. With words did she plead with her husband: the wife did

$$
\text { hight }
$$

He be told most truly what visions had come unto her From the Holy Man; and she bade him for help

To save His life. "I have seen here so much through Him, So many strange things, that well do I know that the sins Shall thrive indeed of any aethling Who so recklessly hopes to rob Him of life." The messenger went on his way, until he did find the folk-warden,

The duke sitting there among the throng of the people On the stony way, there where the street

Is fused together with rocks. And he fared to his lord And told the word of the wife unto him. And the folkwarden

Became troubled of soul, and he went inside.

The thoughts in his breast grew fearful, for both were grievous for him:

That they should slay Him, who was free of sin, And that before this crowd he dared not leave that task undone

Because of the people's word. But then it was turned, The heart in his breast, as the host of the Jews did so want it

To work their will. He warded from himself

Not a single, dire sin, which he himself there did. He hight them bring him a clear fount for his hands, Bring him water in a vessel, as he verily sat in front of the folk

And the thane of Caesar washed himself 'fore the throng, The harsh leader of hosts, and to the horde he did speak, Said that he was freeing himself from such sinful deeds, Such wrongful works; "Nor will I be responsible," quoth he,

"Even one whit for this Holy Man; but ye alone shall carry out all 
With your words and your works - all which ye do Him here to His woe."

Then all the clanships of Jews cried out together, The mighty multitude; quoth that against this man

They would carry out sentence for His evil deeds. "Let His gore drip down -

His blood over us, and the bane of death - and over our bairns as well -

O'er our children's children coming thereafter - we shall still be responsible

For the slaying itself - supposing we commit thereby a $\operatorname{sin!"}$

There before the throng of the Jews the Best of All Men was then given

Into the hand of the haters, held tightly by chains, Forced into fetters - so the foe did receive Him -

Those who did loathe Him: the land-folk encircled Him, The churls evil-minded. The Mighty Lord

Suffered patiently all that the people did unto Him.

They hight $\mathrm{He}$ be flogged before they would rob Him

Of His life, of His age; and under His eyes they spat at Him.

They held Him up to their scorn, and with their hands they did strike Him,

The men, 'gainst His cheeks, and of His garments they stripped Him,

And then renegades robbed Him and took His red robe, And gave Him another - ungracious were they And a wonderous headband, a crown of hard thorns They hight wound round, and hight it be set on AllWielding Christ,

On Him there, Himself. And the thralls went to Him, In kingly way did address Him, and fell on their knees, And bowed their heads unto Him: in mockery of Him they so did.

But all patiently $\mathrm{He}$ bore it, the Lord of the Peoples, The Mighty One, for His love for the children of men. 
Then they hight that the men work with the weapon's edge, Make with their hands out of the hard wood A great, strong cross, and they hight that Christ, God's Blessed Bairn be brought there Himself;

Hight that they lead Him, our Lord, where He was to bleed

And to die - He without sin. And the Jews all went, The world-men, all willingly and led All-Wielding Christ, The Dear Lord to His death. Dire things one could hear, Grievous and wrong; groaning, the women did go, Did follow with weeping, and the men were wailing, Those come from Galilee, who did go with them, Faring from far-off ways. For the death of their Fair Lord They were sorrowing sorely. But He Himself, looking back, did see them,

Hight that they weep not, "Nor may ye sorrow one whit For My wayfaring hence, but your wicked words Ye may bewail and lament with your weeping, With your bitter tears. For the time will come When the mothers will rejoice, the maids of Judea, that in their lives

No bairn was e'er born unto them. For then will ye bitterly pay

For your wrongs, right grimly. Then would ye be glad If the high mountains did hide you down here, And bury you deeply. Death would be dearer, Lovelier for all in the land, than to suffer the loathsome

Murder of mankind, which will come here to the kinships of men."

\section{LXVI}

Then they set up the gallows on the sandy ground, High on the field, the folk of the Jews: The beam on the hillside; and God's Bairn was tormented Thereon, on the cross. They struck cold iron 
Now in their eagerness, nails sharp and new, Hard with their hammers, through His hands and His feet: Bitter bonds were they. His blood ran to earth, The gore of our Good Lord. But this grim deed He cared not

To avenge 'gainst the Jews, but He bade God the Father, The Almighty Lord, that He be not wrathful

'Gainst these men, this world-folk, "Since they wit not what they do," quoth He.

Then the war-men dealt out the weeds of the Lord,

Divided Christ's clothing - coarse men of the foe His fair, rich robes. But the men could not rightly

Become of one mind about the division

Until in their crowd they had cast down lots, Which of them was to have this holy garment, The most winsome of weeds. The world-folk's herdsman, The duke himself, hight that over the head

Of Christ on the cross there be writ that this be the true king of Jews,

Jesus of Nazareth-burg, who stood there nailed

On the new gallows because of grim hatred -

On the beam of the rood. Then the folk bade him

To change that word, quoth that He Himself had so said as He wished,

Had spoken so of Himself, that He wielded power over the people,

Was King over the Jews. Then Caesar's envoy spoke once again,

The harsh leader of hosts: "Over His head it is now so writ,

So wisely inscribed, and I choose not to change it."

The people of Jews then put on each side

Of Christ on the cross two men condemned for their crimes

And left them there tortured on the gallows-tree as reward

For their works, for their loathsome deeds. And the landfolk did speak 
Many harsh words of scorn unto Holy Christ, And with yelps they did greet Him; they saw the Best of all Men

Tormented there on the cross: "If Thou beest King over all," quoth they,

"The Son of the Lord, as Thou Thyself hath spoken, Save Thou Thyself from Thy suffering. Make Thyself free of such hate!

Go hence hail and well. Then will this host, The bairns of the folk believe Thee." So also spoke blasphemy

A most arrogant Jew who stood at the gallows.

"Woe to the world," quoth he, "if Thou didst wield power over it!

Thou sayest Thou canst cast down in one day The high, noble house of the King of Heaven, The greatest of stoneworks, and make it stand once more On the third day. Up to this time no man of the people Hath dared to bring such to pass. But see, how Thou now standeth in fetters

And in sore distress; nor canst Thou save e'en Thyself One whit from this pain." Then, too, one of the thieves In fetters there did speak - when he heard the folk Uttering wicked words - for his will was ne'er good, The thoughts of this thrall. "If Thou beest King of this folk," quoth he,

"Christ, Son of God, go Thou down from the cross, Slip loose from these snares and save us all, Help us together. If Thou beest the Heaven-King, Wielder over this world, make it known through Thy works, Reveal Thyself to these many!" Then spake the other man Hanging there who stood held in his fetters, Suffering great pain. "Wherefore wilt thou speak such a word,

Greetest thou Him with such scorn? Thou standeth here held to the gallows,

Broken on the beam. We both suffer sorely 
Because of our sin: our own deeds themselves Have brought us our pain. But He standeth there, Faultless and free of all sin; for He Himself Hath committed no crime; but for the hate of the crowd He willingly endureth dire pain in this world.

I shall most willingly believe," quoth he, "and shall eagerly bid Him,

The Son of the Lord, the Warder of Lands, That Thou thinkest of me and that Thou beest my help, O Best of All Rulers, when Thou reachest Thy realm Have mercy on me!" Then Christ Savior did speak

Unto him with His words. "Verily I say unto Thee," quoth $\mathrm{He}$,

"That still on this day thou shalt see God's light

Together with $\mathrm{Me}$ in the kingdom of Heaven, In Paradise, though thou art now in such pain." There stood also Mary, the mother of Christ, Bleached pale 'neath the beam, and beheld her Bairn tortured, Suffering such agony. And there were also women there come With her for love of Him, who was the Almighty. And John stood there, too, the disciple of Christ, Sadly beneath His Lord; and his spirit was sore, Grieved for this death. Then Christ the Great Lord did speak,

The Mighty One to His mother: "To My disciples

I hereby consign thee, to him who standeth here before Me.

Enter thou into his household. Thou shalt have him for a son."

Then He greeted John there, hight that he care for her well,

Love her so mildly, as one should one's mother, This maid without stain. Pure of mind, he received her Into his care, as his Lord had commanded. 
Then at the mid-hour of day a mighty token Was wonderously revealed over the whole of the world, When they had raised God's Son onto the gallows, Christ onto the cross: then it became known everywhere How the sun was made swarthy, nor could its fair shimmering, light

Shine down any longer, but its rays were surrounded

With darkness and gloom, and dim fogs did o'ercast it.

Thus came the dreariest day, the greatest darkness

Over the whole, wide world, as long as the All-Wielder

Christ, suffered pain on the cross, the Richest of Kings,

Till the ninth hour of day. Then the midsts did divide,

The swarthiness scattered, and the light of the sun

Appeared clear in the heaven. Then the Strongest of Kings,

The Greatest, cried up to God, as He stood on the cross, Fingers and arms fast bound in their fetters. "Father Almighty," cried He,

"Wherefore hast Thou so forsaken Me, Thou My Dear Lord, Thou Holy Heaven-King? And leavest Thy help, Thy support so far? I stand 'mid the foe

So terribly tortured." Then truly the folk of the Jews

Laughed to revile Him. They heard Holy Christ, The Lord, before His death, ask for a drink, Heard Him say that He thirsted; but the throng could not cease their harrying,

His wicked foes. But there was in them a great wish To bring unto Him still something more of bitterness, And the sin-minded folk had mixed for Him

Vinegar, unsweet, and gall, and a man stood ready A right guilty scoundrel whom they had chosen for this, Had enticed with their speech, so that he took a sponge Loaded with the most loathsome of wines; on a long shaft he put it,

Bound to a beam; and to God's Bairn he did give it, 
Into the mouth of the Mighty One. Christ saw through this murky deed,

Felt well its treachery - He no longer cared to taste Of such bitterness; but the Bairn of God cried aloud

To His Father in Heaven. "Into Thy hands I commend Myself," quoth $\mathrm{He}$,

"My ghost, My spirit unto God's will. It is now good, It is ready to come unto Thee." The Lord of All Peoples

Inclined His head, and His holy breath

Escaped from His body. As now the Warder of Lands

Died in His ropes, there was straightway revealed

A right wonderous token: so that the Wielder's death

Would be made known to the speechless many

And His end-day fulfilled. The earth did tremble,

And the high mountains shook, and the hard stone split open,

The crags on the fields; and the fair curtain was rent,

Was torn in two down the middle - that veil in the temple

Which had hung there unharmed and most wonderously

Broidered for many a day - for the bairns of mankind, The people were never permitted to see what holy things Hung hidden behind that veil. Now they could see the hoard:

The Jewish folk could now gaze on it. And the graves of dead men

Burst open and wide; and in their bodies They rose up living out of the earth All through the strength of the Lord - and were there revealed

As a marvel to men. This was a mighty thing, That so much should feel, should recognize, too, The death of the Christ: so many a thing that had never spoken

One word to any man in this world. Verily the folk of the Jews

Saw many strange things; but their cruel spirits Had grown so hard in their hearts, that there was no holy sign, 
No token revealed unto them, which made them trust more

In Christ's might and strength: that He was the King

Over all the peoples of world. But some spoke with their words,

Some who were set guarding the bodies there in the ground, That this was truly the Son of the All-Wielder,

The Best of All Bairns. Some beat their breasts sorely -

Some weeping women; wonderous pain they felt,

Much hurt in their hearts, at their High Lord's death,

And they were sorely grieved. Now it was the custom of the Jews,

That they did not leave any prisoner hanging there longer

On a holy day, except just as long, until life had glided away,

Till his soul had sunk from him; and the sly, grim-minded men

In their hatred came closer to where, along with the Christ,

The two thieves were nailed, both suffering torture

Along with Him. They were both still alive,

Until the loathsome folk of the Jews

Broke their leg-bones, and both together

Took leave of life, seeking another light.

But they needed not drive Lord Christ to His death

With further sins of that sort; but they found $\mathrm{He}$ had fared thence,

His soul had repaired from here on to the right path,

To long-lasting light. His limbs had grown cold,

The fire had gone from His flesh; then one of the folk went up to Him

With hatred of heart; and in his hand he did bear

A spear, sharp and nailed. And with sword-strength he did thrust it,

Let the point of the weapon cut deep in the wound,

So that on one side Christ's body itself

Was laid open. The landsmen there saw

That the blood and the water - both did spring forth, 
Did well from the wound, as was His will, And as before He had marked it for the kinship of men, For the good of the folk-bairns, and so indeed 'twas fulfilled.

\section{LXVIII}

The bright, shining sun with its beacon of beams

Had sunk down further close to its seat -

On that gloomy day there did come a thane of our Lord:

A clever man was he, a disciple of Christ

For a long time already, although not many a man

Had ken thereof, since with his words he had concealed it indeed

From the people of Jews. Joseph was he hight;

He was his Lord's disciple in secret, and he wished not to follow this sinful folk

In their works of wickedness; but amid the Jewish folk he awaited

The holy kingdom of Heaven. He went hence to speak to the duke,

To make issue with the envoy of Caesar; and he urged him muchly

To release Christ's body from the cross, where it stood in torture,

To let the Good Man be lowered from the gallows and laid in a grave,

Consigned to earth's folds. And the leader of the folk

Did not wish to deny him his will, but did grant him the right

To accomplish his deed. Then he did go forth from there,

Did go to the gallows, where he knew God's Bairn,

Where he knew the body of his Lord was hanging.

From the new rood he did take it and from the nails he freed it,

And into his arms he received it - as one should do for

$$
\text { one's dear lord - }
$$

He took the loved body and wound it with linen 
And carried it carefully - for his Lord was clearly worthy thereof -

To where they had hewn a place with their hands, A spot in the stone, where still no child of mankind, No person had ever been buried. There they placed God's Bairn,

Committed the holiest of corpses, as was their custom, Into the folds of the earth. And with a rock they did close

The goodliest of graves. Grieving, there sat

Women there in their misery, those who had witnessed all, The grim death of the Man. They started to go thence, The weeping women, watching most carefully On what path they should again go back to the grave. They had seen sadness and sorrow aplenty, Mikil grief of their minds: Mary were they both hight, These women in misery. Then was the evening come, The night with its darkness. The dire, hating Jews Gathered again on the morrow, many together... ${ }^{1}$ Speaking in secret: "What, thou knowest surely, That through this One man thy realm was indeed doubtrent,

The people confused. Now lieth He wound-pierced And buried all deeply. He ever did say that $\mathrm{He}$ would arise From the dead on the third day. This many folk do believe. Many people do mark His words. Now order thou a watch, A guard at His grave, lest His disciples

Steal Him away from the stone, and say then that $\mathrm{He}$, Rich and mighty, had risen from His rest. Then the warrior-folk

Will be angered still more, if they begin to announce that about."

Then there were people appointed from the horde of the Jews,

War-men for the watch. They went hence with their weapons:

1 Lucuna in Ms. 
They did go to the grave. There were they to guard The body of God's Bairn. So passed by the holy day Of the Jews and was gone. They sat over the grave, The warriors on watch in the wide, sparkling night, Biding under their shield-boards, until the bright day Came to mankind over the mid-world here, Bringing light to the land-folk. It was not long thereafter That through God's strength the spirit returned Under the hard stone. The Holy breath

Returned to the body. The light was revealed For the boon of mankind, and many a bolt Was unlatched on hell's doors, and the way to Heaven From the world was fashioned. Full radiant arose The Peace-Bairn of God, and $\mathrm{He}$ did go as He willed, So that the wardens of the grave could not recognize Him even one whit -

That ruthless rabble - when He rose from the dead, Arose from His rest. Outside 'round the grave The warriors did sit, the host with their shields, The folk of the Jews. The fair sun strode forward, The clear, winsome light. And the women went forth, Going to the grave, wives of good clan, The Marys most lovely. They had sold much treasure Of silver and gold to buy salves, had sold Much of wealth for herbs and for worts. Whatsoever they could gain,

So that they could embalm the body of their beloved Lord, The Almighty's Son, with their herbs and salves, Him slashed with wounds. The women sorrowed So greatly in spirit, and some of them spoke:

Who would roll it aside, the great stone from the grave For them, the stone which they had seen

The men lay over the corpse, when they had consigned it Into its nook in the rocks. When verily now the women Had gone to the garden, so that they might see the grave itself,

The Almighty's angel did come from the sky above, 
Faring down from the firmament in a shroud of feathers, So that the world, the earth did echo and the men Became weak in their spirits, the watchmen of Jews, And fell down in fright. They feared they would have Their lives not much longer.

\section{LXIX}

The guards lay there,

The thralls, as though dead; then straightway came uncovered The great stone from the grave; for God's angel

Did roll it aside; and the Lord's radiant herald

Did sit him there on the stone; in his face, in his deeds So that all and each might see with their eyes He was as bright and blithe as a bolt of lightning. And his weeds, his vestments were as the winter-cold snow, Then they did see him, sitting there on the stone that was turned -

The women beheld him; and from the brightness

Great fear struck the wives; they were sore afraid And mightily frightened and dared go no further, Dared not go to the grave, until the angel of God, The Wielder's herald, did greet them with words, Quoth that he knew well what their errand, Their work and their will, and the mind of these good wives;

Hight that they fear not, "For I know ye seek Him, Your Lord, Savior Christ, from the city of Nazareth, Him whom the clans of the Jews " did torture and nail to the cross,

Him sinless they laid in the grave. He Himself is not there,

But He hath arisen, and this place standeth empty, This grave in the grotto. Now may ye go nearer, May come much closer; clearly I know that ye long To see inside of the stone; here still is the spot 
Where His body was laid." In their breasts the women, wan though they were

And pale, began to be greatly comforted, The winsome, fair wives. A most welcome message They had heard here - that which the herald of God, The All-Wielder's angel, had said. He hight that they again Go hence from the grave; and go to Christ's followers And say unto His thanes this word most sooth: That their Lord Most Beloved, lo, had arisen from death Most especially he hight that unto Simon Peter

Be told with words this most welcome spell

Of the coming of the Lord: that Christ Himself

Was in Galilee-land, and there again His retainers,

Disciples shall see Him, as He Himself did say

With His words of truth. Just as the wives

Were about to go thence, there stood there before them

Two angels clad all in garments of white,

In weeds, shining and winsome, and with their words

They spoke unto them holy things; and the hearts of the women

Were made anxious with fright, for they feared to look at God's angels,

Could not gaze into the brightness; for the glory of them was too great,

Was too strong to see. Then the Wielder's heralds spoke Again unto them and did ask the women Why they were come to seek Christ the Quick Here 'mid the dead, the Son of the Master, Him filled with life. "Ye shall not find Him Here in this stony grave. But He hath arisen In His body hence; and this shall ye believe; And remember these words, which most verily He Himself hath oft said, when He was with you In Galilee-land: how He would be given over and betrayed, How He would be sold to sinful mankind Into the hand of the hater - the Most Holy Lord So that they would torment Him, and tack Him to the cross, 
Would do Him to death, and that on the third day Through the might of Lord God and for the good of all men,

He would arise, once more living. That verily hath been done now,

Brought to pass 'mid the people. Repair ye swiftly Haste ye hence, and make this known to the followers of

Him.

L X X

He hath gone on ahead and is away

In Galilee-land, and His retainers shall see Him again,

His disciples there." And straightway this was joy,

Was winsomeness for the women, when they heard such words

spoken,

Making known God's might - yet much frightened were they still,

Filled with a fear of Him; and they set them forth

To go from the grave; and unto Christ's disciples they gladly

Did speak of the wonderous sight, while sorrowing still

They bided such bettering. To the bastions were come

The Jewish guardsmen, too, who had sat by the grave

All the long, long night, had lain in watch o'er the corpse,

O'er the body there buried; and while they there bided -

They said unto the host of the Jews - what shock, what fright,

What strange sight came unto them; and they said also with their words

How it was all so done with the might of the Lord;

Nor kept they it hidden within their hearts. And the host of the Jews

Offered to them great treasures both of silver and of gold, Bought from them with bright jewels the promise that they would not tell, 
Nor make this known to the many; "But say ye that with weary minds

Ye did fall asleep; and there did come His disciples And stole Him away from behind the stone. Do ye this ever with zeal,

Go on in eagerness; and if the folk-leader doth gain knowledge thereof,

We shall help you against that high lord, so that no whit of harm,

No grief shall o'ertake you." Then they took great treasures, Precious jewels from the people, but pursued the course they had begun,

For they had no power o'er their will; but they broadcast it widely

To the folk in the land, that such lies were here spread About the Holy Lord. Then were the hearts once more healed

For the disciples of Christ, when they did hear the good wives

Give praise unto God's power. Then their hearts grew joyous,

And both of them ran, rushing swiftly up to the grave, Until soon after Simon Peter did come,

Earl famed for his strength; and he went on

Going straight to the grave; and he saw there the garments

Of God's Bairn, of His Lord, the linen lying there, The beautiful shroud with which His body Had been bound so fairly. Far from that lay the cloth With which Holy Christ's head had been covered, Our Mighty Lord's face, when He lay in this rest. Then John also did go inside the grave To see this strange thing; and straightway thereafter His belief was unlocked, so that he knew that He would again come to this light -

His Lord most dear, would arise from the dead Up out of this earth. Then they again went away, The twain, Peter and John, and the retainers, disciples 
Of Christ came together. With care-filled heart

One of the women stood for a second time

Groaning over the grave - her spirit was grieved -

It was Mary Magdelan - the thoughts of her mind,

Of her soul were seized with sorrow, nor knew she where she should seek Him,

The Lord who would grant her help. She could not leave off her lamenting;

The woman could not cease her weeping. Nor knew she where she could turn.

The thoughts of her mind were distracted. Then she saw Mighty Christ

Standing there - although she could not perceive Him

As someone she knew, until He so wished to reveal it,

Until He would say who He was. He asked what she was bemoaning so sorely.

So terribly there with her hot tears. She told Him she verily knew not

Where they had taken her Lord. "If Thou can'st show me,

O my Lord, if I may ask Thee, if Thou hast taken Him away

From behind these rocks, then instruct me with words that would be my greatest wish:

That I could see Him myself." She knew not 'twas the Son of the Lord

Whom she was greeting with her good speech. She weened 'twas a gardener,

Yard-guardian of his master. Then the Holy Lord did greet her

By name, the Best of All Saviors. And straightway she came closer,

The wife, with good will, and recognized her Savior Himself.

In her love she could not refrain, but with her hands she longed to hold Him,

The woman to touch the World-Lord. "Not yet," quoth $\mathrm{He}$, "have I risen to Him, the

Heavenly Father. 
But haste thou now swiftly, and make it known to the earls, To My brethren here, that I will see Him, The All-Wielder, Father of us both, Yours and Mine, too, Mighty God, true and fast."

\section{LXXI}

The woman was in raptures that she could proclaim such joy,

Could say of Him, that He was sound and was well. Straightway the woman

Was eager to announce this message, and to the earls she did bring it,

Welcome tidings to the warriors: that All-Wielding Christ

She had seen well and sound; and she said that He Himself Had granted unto her this glorious day. They still wished not to trust

The woman's word, that she brought such a message so welcome

Verily from the Son of God, and they sat grieved of heart,

The heroes lamenting. Then Holy Christ, The Lord, revealed Himself openly another time

Since $\mathrm{He}$ rose from the dead. He did so do this

For the sake of the woman, that He met them on the way. He spoke to them as One whom they knew, and they bent their knee before Him,

Fell at His feet. He hight that no fear

Should they bear in their breast. "But unto My brethren Shall ye make known My message, that they shall follow Into Galilee-land. There shall I meet them again."

On that selfsame day of the disciples Two earls early already that morn

Were faring on business. They wished to find them the fortress

Of Emaus, the castle. Among the men many 
A word did begin to wax, as they fared on their way, God's Holy Son. Still could they not know Him one whit, Him the Mighty and Strong. He had no wish to reveal Himself unto them.

Still He went along with them, and $\mathrm{He}$ asked about what they were speaking:

"Why go ye so groaning," quoth $\mathrm{He}$, "Ye twain with such grieving hearts

And souls filled with sorrow?" They straightway replied unto Him,

The earls then gave answer: "Why dost Thou ask so?" quoth they.

"Art Thou from Jerusalem from the folk of the Jews?"...1

The Holy Ghost from the fields of Heaven

With the great strength of Lord God." Now He took those good earls,

His disciples there and He did lead them out, Until He brought them to Bethany.

There He held up His hands and made them holy:

With His words He did bless them. Then He went Him hence, Sought the high realm of Heaven and His holy throne.

And there He doth sit on the right side of God, The Father Almighty. And from there All-Wielding Christ Gazes down and sees what power doth surround the world. Then on the same spot the disciples good Fell down in prayer, and the followers of Christ Fared rejoicing again to Jerusalem.

To the city they hastened, and their hearts were joyous. In the temple they tarried. Truly the strength of the Wielder...

1 Lacuna in Ms. 




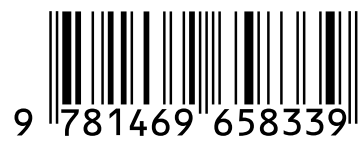

